\title{
\#USGS
}

Prepared in cooperation with the

Massachusetts Department of Environmental Protection

Changes in Phosphorus Congentrations and Loads in the Assabet River, Mlassachusetts, October 200: through Apri] 2014

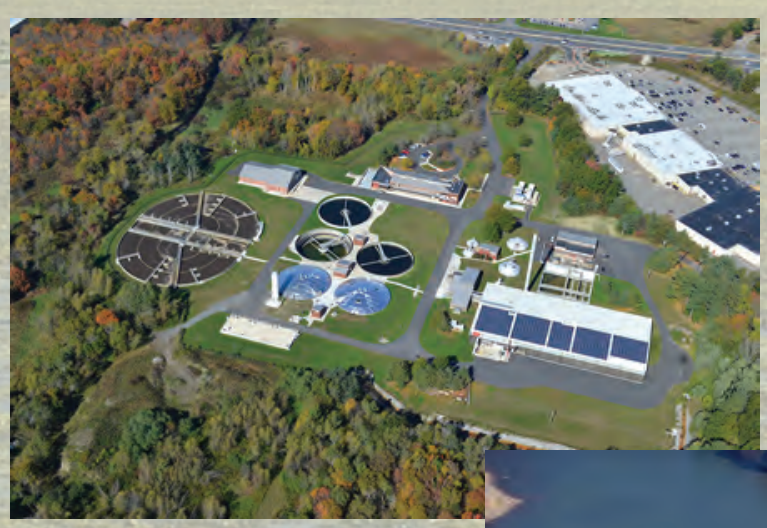

Scientific Investigations Report 2016-5063

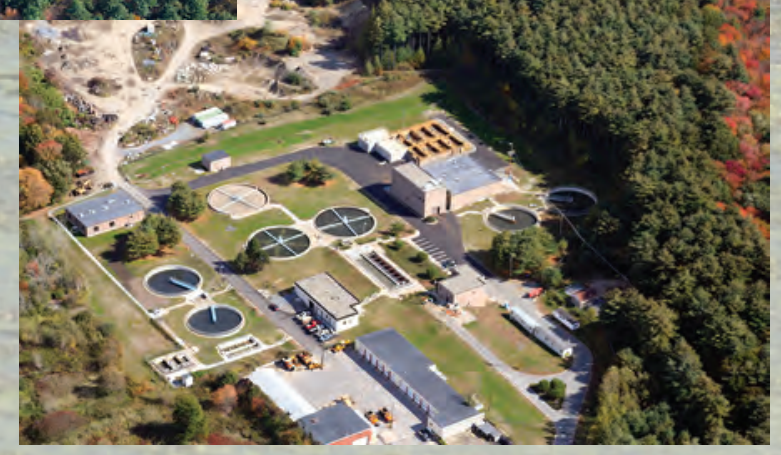


Cover. Inset photographs: Wastewater-treatment plants on the Assabet River in central Massachusetts. Photographs courtesy of the Westborough (top left), Marlborough-Westerly (middle), and Hudson (bottom right) wastewater-treatment plants.

Background photograph: Hudson impoundment on the Assabet River in central Massachusetts. Photograph courtesy of the Organization for the Assabet, Sudbury, and Concord Rivers (OARS). 


\section{Changes in Phosphorus Concentrations and Loads in the Assabet River, Massachusetts, October 2008 through April 2014}

By Jennifer G. Savoie, Leslie A. DeSimone, John R. Mullaney,

Marc J. Zimmerman, and Marcus C. Waldron

Prepared in cooperation with the

Massachusetts Department of Environmental Protection

Scientific Investigations Report 2016-5063 


\title{
U.S. Department of the Interior SALLY JEWELL, Secretary
}

\section{U.S. Geological Survey Suzette M. Kimball, Director}

\author{
U.S. Geological Survey, Reston, Virginia: 2016
}

For more information on the USGS - the Federal source for science about the Earth, its natural and living resources, natural hazards, and the environment-visit http://www.usgs.gov or call 1-888-ASK-USGS.

For an overview of USGS information products, including maps, imagery, and publications, visit http://store.usgs.gov.

Any use of trade, firm, or product names is for descriptive purposes only and does not imply endorsement by the U.S. Government.

Although this information product, for the most part, is in the public domain, it also may contain copyrighted materials as noted in the text. Permission to reproduce copyrighted items must be secured from the copyright owner.

Suggested citation:

Savoie, J.G., DeSimone, L.A., Mullaney, J.R., Zimmerman, M.J., and Waldron, M.C., 2016, Changes in phosphorus concentrations and loads in the Assabet River, Massachusetts, October 2008 through April 2014: U.S. Geological Survey Scientific Investigations Report 2016-5063, 40 p., http://dx.doi.org/10.3133/sir20165063.

ISSN 2328-031X (print) ISSN 2328-0328 (online) ISBN 978-1-4113-4059-6 


\section{Acknowledgments}

This study benefitted greatly from the interest, support, and assistance of many colleagues and agencies. Brian Friedman, Dennis R. Dunn, Alice Rojko, Kimberly Groff, Mark Mattson, and the late Arthur J. Screpetis of the Massachusetts Department of Environmental Protection, Office of Watershed Management, were instrumental in guiding the work. Wastewater-treatmentplant managers Harry Butland of Marlborough's Westerly plant, Christopher Pratt of Veolia's Westborough plant, and Mark Concheri of the Hudson plant directly provided monitoring data of great importance for assessing loads in the Assabet River. American Veterans (AMVETS) Post 208 in Hudson, Massachusetts, gave permission to construct a water-quality-monitoring shelter on its property.

Robert M. Hirsch of the U.S. Geological Survey provided especially beneficial advice and reviews of the statistical analyses. The contributions of many more U.S. Geological Survey personnel (Gardner C. Bent, Jean P. Campbell, Kimberly W. Campo, Timothy R. Driskell, Gerald G. Girouard, Andrew J. Massey, Laura Medalie, Douglas L. Moyer, Stephen G. O’Brien, Roy S. Socolow, Jason R. Sorenson, Britt O. Stock, Andrew M. Waite, Joan S. Whitley, and Joseph F. Whitley) and cooperative-education and other student aides (Gina Daniels, Michael Gowins, Irena Gumennic, Lisa Lach, Marine Langreney, Sandra Petrakis, and Nita Vaidya) are acknowledged. 



\section{Contents}

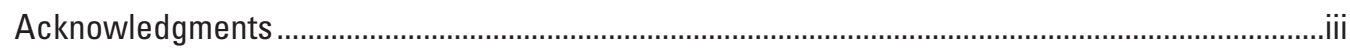

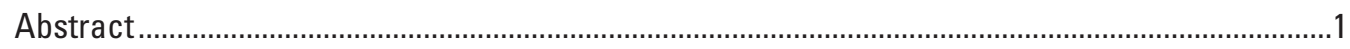

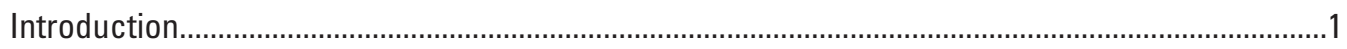

Methods Used to Monitor Changes in Phosphorus Concentrations and Loads ..............................3

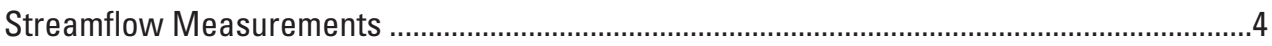

Environmental Sample Collection ...........................................................................................

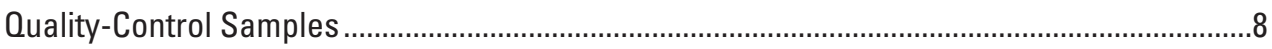

Load Calculations...........................................................................................................

Changes in Phosphorus Concentrations and Loads ...................................................................

Phosphorus Concentrations .............................................................................................

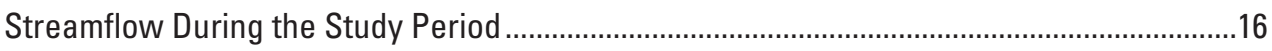

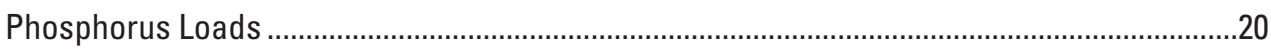

Seasonal Differences in Phosphorus Concentrations and Loads ............................................21

Effects of Impoundments on Instream Phosphorus Loads ..................................................2

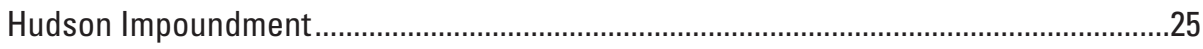

Ben Smith Impoundment .......................................................................................

Statistical Analyses of Changes in Phosphorus Concentrations ..............................................34

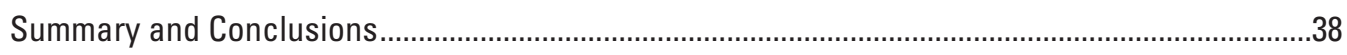

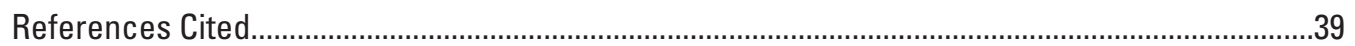

\section{Figures}

1. Map showing locations of water-quality-monitoring stations, wastewatertreatment plants, and impoundment dams in the study area along the Assabet River Basin in central Massachusetts

2. Orthophotograph map identifying the locations of water-quality-monitoring stations Port Street and AMVETS, upstream and downstream from the Hudson impoundment on the Assabet River, Massachusetts.

3. Orthophotograph map identifying the locations of water-quality-monitoring stations Stow and Maynard, upstream and downstream from the Ben Smith impoundment on the Assabet River, Massachusetts

4. Graphs showing streamflow and sample-collection rate, demonstrating the flow-proportional sampling method

5. Graphs showing streamflow and total phosphorus concentrations at the $A$, Port Street and $B$, AMVETS water-quality-monitoring stations, and daily average total phosphorus concentration in effluent from Westborough and MarlboroughWesterly wastewater-treatment plants, in the Assabet River, Massachusetts, 2008-2014

6. Graphs showing streamflow and total phosphorus concentrations at the $A$, Stow and $B$, Maynard water-quality-monitoring stations, and daily average total phosphorus concentration in effluent from Westborough, MarlboroughWesterly, and Hudson wastewater-treatment plants, in the Assabet River, Massachusetts, 2008-2014 
7. Graphs showing streamflow and orthophosphate concentrations at the $A$, Port Street and $B$, AMVETS water-quality-monitoring stations on the Assabet River, Massachusetts, 2008-2014

8. Graphs showing streamflow and orthophosphate concentrations at the A, Stow and $B$, Maynard water-quality-monitoring stations on the Assabet River,

Massachusetts, 2008-2014

9. Boxplot showing annual distributions of estimated daily concentrations of total phosphorus in wastewater-treatment-plant effluent to the Assabet River, Massachusetts, 2009-2013

10. Boxplots showing annual distributions of estimated daily concentrations of $A$, total phosphorus and $B$, orthophosphate in weekly flow-proportional composite samples from four water-quality-monitoring stations on the Assabet River, Massachusetts, 2009-2013

11. Graphs showing relations between streamflow and instream concentrations of total phosphorus at four water-quality-monitoring stations on the Assabet River, Massachusetts, before and after wastewater-treatment-plant (WWTP) upgrades to reduce phosphorus in WWTP effluent

12. Graph showing interquartile range of mean daily streamflow from 1942 to 2014 at station 01097000 repeated for each calendar year and overlaid with daily mean streamflow during the study period, from October 1, 2008, to April 30, 2014, Assabet River, Maynard, Massachusetts.

13. Boxplot showing annual distributions of estimated daily total phosphorus loads in wastewater-treatment-plant effluent into the Assabet River, Massachusetts, 2009-2013

14. Boxplots showing annual distributions of estimated $A$, total phosphorus and $B$, orthophosphate loads in weekly flow-proportional composite samples from four water-quality-monitoring stations on the Assabet River, Massachusetts, 2009-2013...22

15. Boxplots showing seasonal distributions of estimated daily total phosphorus concentrations in effluent from the wastewater-treatments plants in $A$, Westborough, $B$, Marlborough-Westerly, and $C$, Hudson, Massachusetts, during nongrowing and growing seasons, on the Assabet River, Massachusetts, 2009-2014.

16. Boxplots showing seasonal distributions of estimated daily total phosphorus loads in effluent from the wastewater-treatment plants in $A$, Westborough, $B$, Marlborough-Westerly, and $C$, Hudson, Massachusetts, during nongrowing and growing seasons, 2009-2014

17. Boxplots showing seasonal distributions of estimated daily total phosphorus concentrations in flow-proportional composite samples from water-qualitymonitoring stations $A$, Port Street, $B$, AMVETS, $C$, Stow, and $D$, Maynard during nongrowing and growing seasons, on the Assabet River, Massachusetts, from 2009 to 2014

18. Boxplots showing seasonal distributions of estimated daily orthophosphate concentrations in flow-proportional composite samples from water-qualitymonitoring stations $A$, Port Street, $B$, AMVETS, $C$, Stow, and $D$, Maynard during nongrowing and growing seasons, on the Assabet River, Massachusetts, from 2009 to 2014

19. Boxplots showing seasonal distributions of estimated daily total phosphorus loads in flow-proportional composite samples from water-quality-monitoring stations $A$, Port Street, $B$, AMVETS, $C$, Stow, and $D$, Maynard during nongrowing and growing seasons, on the Assabet River, Massachusetts, from 2009 to 2014 
20. Boxplots showing seasonal distributions of estimated daily orthophosphate loads in flow-proportional composite samples from water-quality-monitoring stations $A$, Port Street, $B$, AMVETS, $C$, Stow, and $D$, Maynard during nongrowing and growing seasons, on the Assabet River, Massachusetts, from 2009 to 2014.

21. Bar graphs showing estimated annual loads of $A$, total phosphorus of discharges from wastewater-treatment plants at Westborough and Marlborough-Westerly and instream at the Port Street and AMVETS water-quality-monitoring stations and $B$, orthophosphate instream at the Port Street and AMVETS water-qualitymonitoring stations on the Assabet River, Massachusetts, 2009-2013.

22. Graphs showing streamflow and differences between estimated weekly loads of $A$, total phosphorus and $B$, orthophosphate upstream and downstream from the Hudson impoundment on the Assabet River, Massachusetts, October 2008 through April 2014.

23. Bar graphs showing estimated annual loads of $A$, total phosphorus discharges from the wastewater-treatment plants at Westborough, Marlborough-Westerly, and Hudson and instream at the Stow and Maynard water-quality-monitoring stations and $B$, orthophosphate instream at the Stow and Maynard water-qualitymonitoring stations on the Assabet River, Massachusetts, from 2009 to 2013.

24. Graphs showing streamflow and differences between estimated weekly loads of $A$, total phosphorus and $B$, orthophosphate upstream and downstream from the Ben Smith impoundment on the Assabet River, Massachusetts, October 2008 through April 2014.

25. Graphs showing relations between streamflow and total phosphorus concentrations, and total phosphorus concentrations predicted for before and after the wastewater-treatment-plant upgrades, based on linear regression modeling for data from October 2008 through April 2014 for water-quality-monitoring stations on the Assabet River in the towns of Hudson, Stow, and Maynard, Massachusetts .....37

\section{Tables}

1. Location coordinates, drainage-basin areas, and annual mean daily and annual total streamflow (calendar years 2008 to 2013) for water-quality-monitoring stations on the Assabet River in the towns of Hudson, Stow, and Maynard, Massachusetts.......6

2. Median and mean flow and total phosphorus concentrations and loads at wastewater-treatment plants in the towns of Westborough, Marlborough, and Hudson on the Assabet River, Massachusetts, 2009 through 2013.

3. Median and mean flow and total phosphorus and orthophosphate concentrations and loads at water-quality-monitoring stations on the Assabet River in the towns of Hudson, Stow, and Maynard, Massachusetts, 2009 through 2013

4. Coefficients and other regression metrics for linear regression models used to describe the relations between the natural log of composite total phosphorus concentrations and mean streamflow, and periods before and after wastewatertreatment-plant upgrades, for data collected from October 2008 through April 2014 at water-quality-monitoring stations on the Assabet River in the towns of Hudson, Stow, and Maynard, Massachusetts.

5. Results of pairwise F-test comparison of linear regression models 1, 2, and 3 for four water-quality-monitoring stations on the Assabet River, Massachusetts. 


\section{Conversion Factors}

U.S. customary units to International System of Units

\begin{tabular}{lcl}
\hline \multicolumn{1}{c}{ Multiply } & By & \multicolumn{1}{c}{ To obtain } \\
\hline inch (in.) & Length & \\
inch (in.) & 2.54 & centimeter $(\mathrm{cm})$ \\
mile (mi) & 25.4 & millimeter $(\mathrm{mm})$ \\
\hline & 1.609 & kilometer $(\mathrm{km})$ \\
\hline square mile $\left(\mathrm{mi}^{2}\right)$ & Area & \\
\hline & 2.590 & square kilometer $\left(\mathrm{km}^{2}\right)$ \\
\hline ounce, fluid (fl. oz) & Volume & \\
gallon (gal) & 29.57 & milliliter $(\mathrm{mL})$ \\
\hline & 3.785 & liter $(\mathrm{L})$ \\
\hline cubic foot per second (ft $\left.{ }^{3} / \mathrm{s}\right)$ & Flow rate & \\
cubic foot per year $\left(\mathrm{ft}{ }^{3} / \mathrm{yr}\right)$ & 0.02832 & cubic meter per second $\left(\mathrm{m}^{3} / \mathrm{s}\right)$ \\
million gallons per day $(\mathrm{Mgal} / \mathrm{d})$ & 0.02832 & cubic meter per year $\left(\mathrm{m}^{3} / \mathrm{yr}\right)$ \\
\hline & 0.04381 & cubic meter per second $\left(\mathrm{m}^{3} / \mathrm{s}\right)$ \\
\hline pound, avoirdupois $(\mathrm{lb})$ & Mass & \\
pound per day (lb/d) & 0.4536 & kilogram $(\mathrm{kg})$ \\
pound per year $(\mathrm{lb} / \mathrm{yr})$ & 0.4536 & kilogram per day $(\mathrm{kg} / \mathrm{d})$ \\
\hline
\end{tabular}

\section{Datum}

Horizontal coordinate information is referenced to the North American Datum of 1983 (NAD 83).

\section{Supplemental Information}

Concentrations of chemical constituents in water are given in milligrams per liter (mg/L) as phosphorus. 


\section{Abbreviations}

$\begin{array}{ll}\text { AMVETS } & \text { American Veterans } \\ \text { EPA } & \text { U.S. Environmental Protection Agency } \\ \text { EWI } & \text { equal-width increment } \\ \text { IGS } & \text { inside grab sample } \\ \text { MDL } & \text { method detection limit } \\ \text { NWQL } & \text { National Water Quality Laboratory } \\ \text { orthoP } & \text { orthophosphate } \\ \text { R } & \text { R-squared (the coefficient of determination) } \\ \text { RPD } & \text { relative percent difference } \\ \text { TMDL } & \text { total maximum daily load } \\ \text { TP } & \text { total phosphorus } \\ \text { USGS } & \text { U.S. Geological Survey } \\ \text { WWTP } & \text { wastewater-treatment plant }\end{array}$





\title{
Changes in Phosphorus Concentrations and Loads in the Assabet River, Massachusetts, October 2008 through April 2014
}

\author{
By Jennifer G. Savoie, Leslie A. DeSimone, John R. Mullaney, Marc J. Zimmerman, and Marcus C. Waldron
}

\section{Abstract}

Treated effluent discharged from municipal wastewatertreatment plants to the Assabet River in central Massachusetts includes phosphorus, which leads to increased growth of nuisance aquatic plants that decrease the river's water quality and aesthetics in impounded reaches during the growing season. To improve the river's water quality and aesthetics, the U.S. Environmental Protection Agency approved a total maximum daily load for phosphorus in 2004 that directed the wastewater-treatment plants to reduce the amount of total phosphorus discharged to the river by 2012. The permitted total phosphorus monthly average of 0.75 milligrams per liter during the aquatic plant growing season (April 1 through October 31 ) was reduced by the total maximum daily load to a target of 0.1 milligrams per liter by 2012, and the nongrowingseason limit was unchanged at 1.0 milligrams per liter.

From October 2008 through April 2014, the U.S. Geological Survey, in cooperation with the Massachusetts Department of Environmental Protection, measured streamflow and collected weekly flow-proportional, composite samples of water from the Assabet River for analysis of concentrations of total phosphorus and orthophosphate. Streamflow and concentration data were used to estimate total phosphorus and orthophosphate loads in the river. The purpose of this monitoring effort was to evaluate phosphorus concentrations and loads in the river before, during, and after the wastewater-treatment-plant upgrades and to assess the effects of seasonal differences in permitted discharges. The locations of water-quality-monitoring stations, with respect to the Hudson and Ben Smith impoundments, enabled examination of effects of phosphorus entering and leaving the impoundments.

Annual median concentrations of total phosphorus in wastewater-treatment plants were reduced by more than 80 percent with the plant upgrades. Measured instream annual median concentrations of total phosphorus in the Assabet River decreased by about 38 to 50 percent at three of the four monitoring stations following the wastewater-treatment-plant upgrades. At the station farthest upstream, the median total phosphorus concentration remained unchanged throughout the study; this may be attributed to the site location and potential resuspension of particulate organic matter during periods of increased streamflow. Annual median loads from the wastewater-treatment plants were reduced by up to 91 percent following the upgrades, instream annual median total phosphorus loads at the three downstream stations decreased by 71 to 76 percent, and instream orthophosphate loads at the three downstream stations decreased by 79 to 87 percent.

Seasonal fluctuations (growing versus nongrowing) of total phosphorus and orthophosphate were observed instream before the upgrades. However, after the upgrades, fluctuations in phosphorus released from the treatment plants were slight and seasonal changes were typically not observed instream.

Annual loads entering and leaving the two impoundments were inconclusive in determining whether the impoundments were sources or sinks of total phosphorus during the study. Total phosphorus loads entering the Hudson impoundment were consistently greater than those leaving; however, there was uncertainty about the loads at the monitoring station upstream from this impoundment. At the Ben Smith impoundment, total phosphorus and orthophosphate loads downstream were slightly greater than those upstream from the impoundment, but the differences may reflect additions from tributaries and overland runoff.

Estimated instream total phosphorus concentrations and loads indicated that the decreases in total phosphorus in wastewater-treatment-plant discharges were accompanied by reductions measured in the Assabet River. A statistical analysis which incorporates the effect of varying flow conditions demonstrated significant reductions in total phosphorus concentrations after the wastewater-treatment-plant upgrades at three of the four instream monitoring stations. No significant change was observed at the most upstream location, the Assabet River at Port Street at Hudson, Massachusetts (station number 01096835), which may have been affected by flow-related resuspension of particulate phosphorus.

\section{Introduction}

The 33-mile Assabet River flows from its headwaters in Westborough, Massachusetts, to its confluence with the Sudbury River in Concord, Mass., where they form the Concord River (fig. 1; Sudbury and Concord Rivers are 


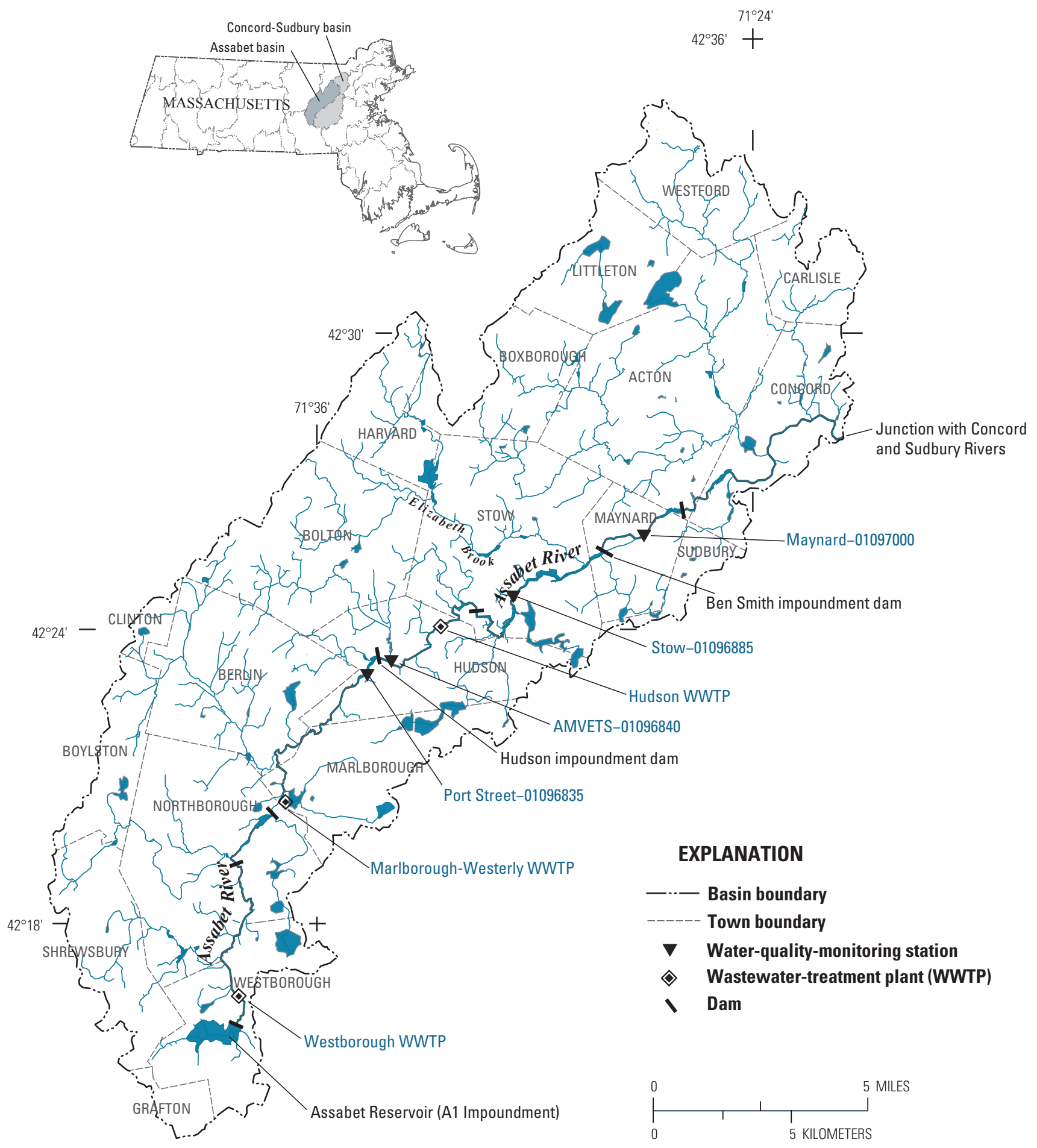

From U.S. Geological Survey and Massachusetts Office of Geographic Information data sources, Massachusetts State Plane Coordinate System, Mainland Zone

Figure 1. Locations of water-quality-monitoring stations, wastewater-treatment plants, and impoundment dams in the study area along the Assabet River Basin in central Massachusetts. See table 1 for full station names. Modified from Zimmerman and Sorenson (2005, fig. 1). 
outside the study area and not shown on any figure). The Assabet River is impaired throughout much of its course by high concentrations of nutrients, especially phosphorus. Land use in the basin is primarily forested or open and residential, with smaller fractions of commercial, industrial, and agricultural land use. All or parts of 20 towns or small cities lie in the basin, with urban (or developed) areas clustered along the Assabet River. Sources of phosphorus in the basin include discharge from wastewater treatment plants and stormwater runoff (Massachusetts Department of Environmental Protection, 2004). In 2004, the U.S. Environmental Protection Agency (EPA) approved a total maximum daily load (TMDL) for the Assabet River, which allocates phosphorus loads to each of the sources and defines a set of actions to bring the river into compliance with waterquality standards (U.S. Environmental Protection Agency, 2015a). The TMDL established wasteload allocations for the wastewater-treatment plants (WWTPs) in Westborough, Marlborough, Hudson, and Maynard, Mass., to reduce the amounts of total phosphorus (TP) discharged to the Assabet River in treated wastewater effluent by 2012 (Massachusetts Department of Environmental Protection, 2004). As stated in the TMDL, monthly mean concentrations of total phosphorus in effluent are not to exceed 0.1 milligrams per liter $(\mathrm{mg} / \mathrm{L})$ (previous limit of $0.75 \mathrm{mg} / \mathrm{L}$ ) from April through October, the primary growing season for nuisance aquatic plants. During the nongrowing season (November through March), the WWTPs are allowed to continue with the previously allowed restriction of monthly mean concentrations of total phosphorus in effluent of no more than $1.0 \mathrm{mg} / \mathrm{L}$. The WWTPs achieved compliance with their wasteload allocations at different times because of different construction schedules; the Hudson WWTP was the first to reduce TP concentrations in October 2009, followed by the Marlborough-Westerly WWTP in January 2012 and the Westborough WWTP in March 2012. The Maynard WWTP, which was downstream from the study area, achieved compliance in 2011. A report published by the EPA (2015b) describes the individual WWTP upgrades, treatment methods for removing TP, and the costs involved.

The TMDL was designed to have a phased approach. The first step is to reduce concentrations of WWTP phosphorus discharge in the hope that by doing so, water-quality conditions would improve in the Assabet River with reduced aquatic biomass, decreased diurnal fluctuations of dissolved oxygen concentrations caused by the growth of the floating and rooted macrophytes, and decreased phosphorus flux to and from riverine sediments (Massachusetts Department of Environmental Protection, 2004). Through the adaptive management approach of the TMDL, the EPA can require further reductions in concentrations of total phosphorus in WWTP releases and consider sediment dredging and dam removal if the water-quality standards are not achieved through the WWTP reductions of TP.

The U.S. Geological Survey (USGS), in cooperation with the Massachusetts Department of Environmental Protection, conducted a study designed to document the water-quality changes downstream from the WWTPs in the Assabet River, before, during, and after implementation of the TP TMDL. The study objectives addressed in this report are to (1) document changes in phosphorus concentrations and loads in the Assabet River before, during, and after implementation of the TMDL; (2) determine the effects of seasonal differences in permitted phosphorus releases on instream concentrations and loads; and (3) examine the effects of two impounded reaches on phosphorus concentrations and loads.

This report presents analysis of data on concentrations of total phosphorus and orthophosphate (orthoP) and streamflow that were collected at four water-quality-monitoring stations on the Assabet River from October 2008 through April 2014, a period that extends before, during, and after implementation of the TMDL phosphorus-reduction requirements at the WWTPs. The report describes how monitoring data were used to calculate daily phosphorus loads, aggregated to seasons and calendar years. The magnitudes of the concentration and load reductions achieved by the WWTPs and those observed at the instream monitoring stations are compared. The effects of two impoundments on phosphorus dynamics are assessed, and the results of an analysis of covariance used to compare TP reductions to streamflow are examined. Zimmerman and Savoie (2013) summarizes previous studies that were used to develop the TMDL and understand nutrient cycling and sediment phosphorus flux in relation to the biomass distribution in the impounded reaches of the Assabet River.

\section{Methods Used to Monitor Changes in Phosphorus Concentrations and Loads}

Instream nutrient concentrations in the Assabet River can change rapidly and continuously as a result of many factors, including storm runoff, groundwater discharge, interactions with streambed and streambank sediments, and normal operation of the WWTPs. High-frequency (hourly to weekly) changes in instream phosphorus concentrations are not captured by conventional, discrete water-quality sampling. To ensure that the variable phosphorus concentrations in the river were adequately measured in this study, flow-proportional water-quality sampling and streamflow monitoring were used to estimate TP and orthoP loads. Water-quality samples were composited over weeklong sample-collection periods throughout the 5-year study period. TP and orthoP loads were estimated by multiplying constituent concentrations measured in the composite samples by the streamflow (the volume of water moving past the sampling point per unit of time) during the sampling period. Continuous, flow-proportional sampling captures the short-term, rapid increases and decreases in concentration and flow that occur during storm events, which can substantially influence the total loads carried by the river.

Water-quality samples and streamflow data were collected from October 2008 through April 2014 at four monitoring stations: station number 01096835, Assabet River 
at Port Street at Hudson, Mass. (Port Street); 01096840, Assabet River 200 feet below State Route 85 at Hudson, Mass. (AMVETS); 01096885, Assabet River at Sudbury Road near Stow, Mass. (Stow); and 01097000, Assabet River at Maynard, Mass. (Maynard). The monitoring stations bracket two shallow impoundments created by old mill dams: Hudson impoundment (in Hudson) and Ben Smith impoundment (in Stow and Maynard) (figs. 2 and 3; table 1). The Hudson impoundment is downstream from the Westborough and Marlborough-Westerly WWTPs; the Ben Smith impoundment is downstream from the Westborough, Marlborough-Westerly, and Hudson WWTPs. Additional descriptions of the monitoring stations and of the sampling and analysis methods can be found in Zimmerman and Savoie (2013).

\section{Streamflow Measurements}

Streamflow, in cubic feet per second $\left(\mathrm{ft}^{3} / \mathrm{s}\right)$, was estimated from continuous measurements of stream stage and the development of a stage-discharge relation at each of the four water-quality-monitoring stations on the Assabet River. A submersible pressure transducer at each station monitored

$71^{\circ} 34^{\prime} 30^{\prime \prime}$

$71^{\circ} 34^{\prime}$

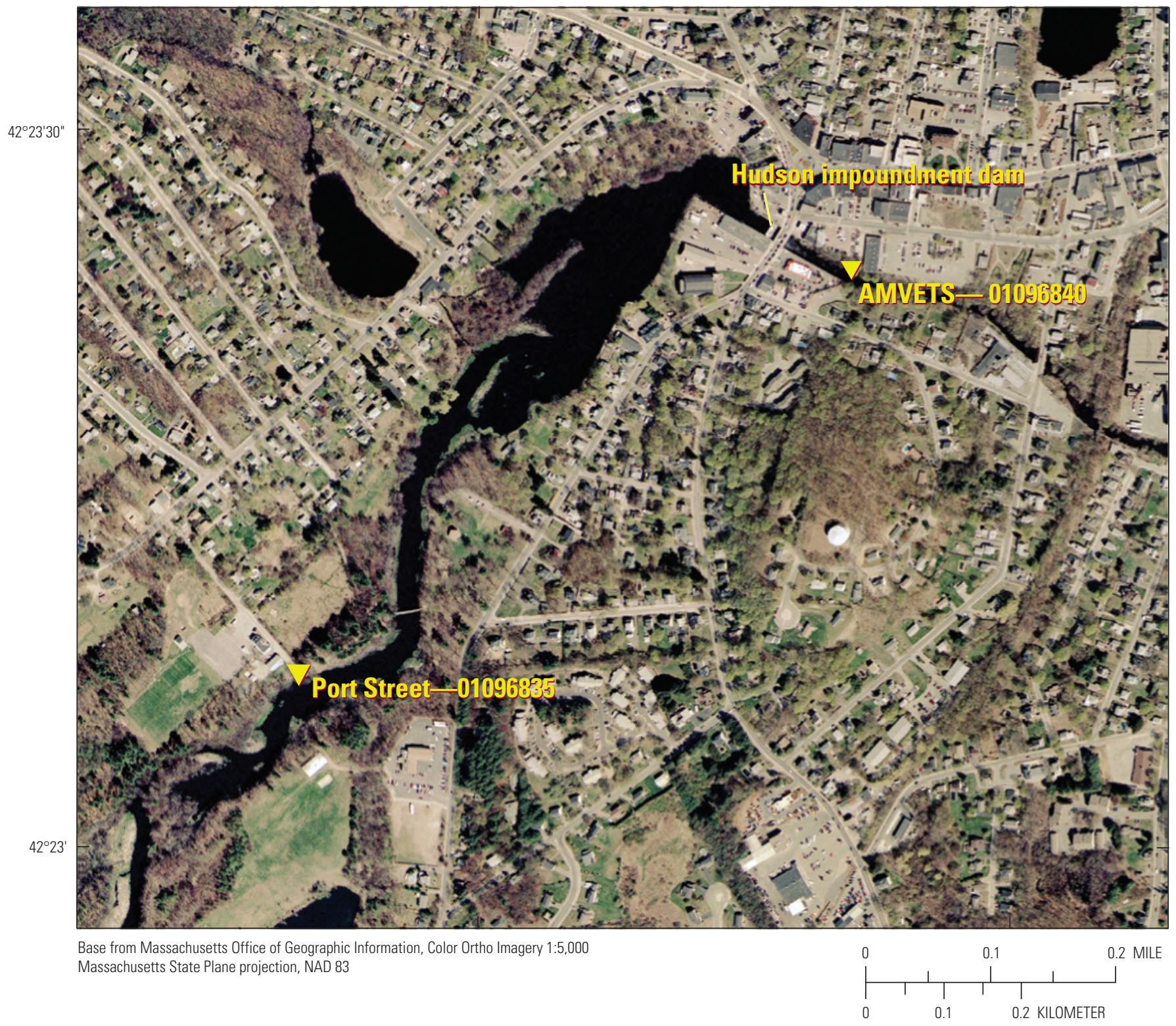

Figure 2. Orthophotograph map identifying the locations of water-quality-monitoring stations Port Street (01096835) and AMVETS (01096840), upstream and downstream from the Hudson impoundment on the Assabet River, Massachusetts. See table 1 for full station names. Modified from Zimmerman and Savoie (2013, fig. 2). 
stream stage at 15-minute intervals. Manual measurements of streamflow, calculated as the product of measured stream velocity and stream cross-sectional area, were made every 6 to 8 weeks to develop the site-specific stage-discharge relations (Rantz and others, 1982).

\section{Environmental Sample Collection}

Composite, flow-proportional samples were collected with portable automatic samplers outfitted with four-bottle racks and controlled by dataloggers. The weekly composite target was 32 subsamples (the approximate number of 100-milliliter [mL] samples that the sample bottle could hold). Every week, the average daily streamflow for the upcoming week was estimated; the estimate was used to calculate a threshold volume that would activate the automated sampler. Samples were collected more frequently on the days with greater streamflow volumes; this is what is meant by "flowproportional sampling" (fig. 4).

When the streamflow threshold was exceeded, a signal was transmitted to the automated sampler, causing it to purge the suction line and collect two 100-mL aliquots of water.

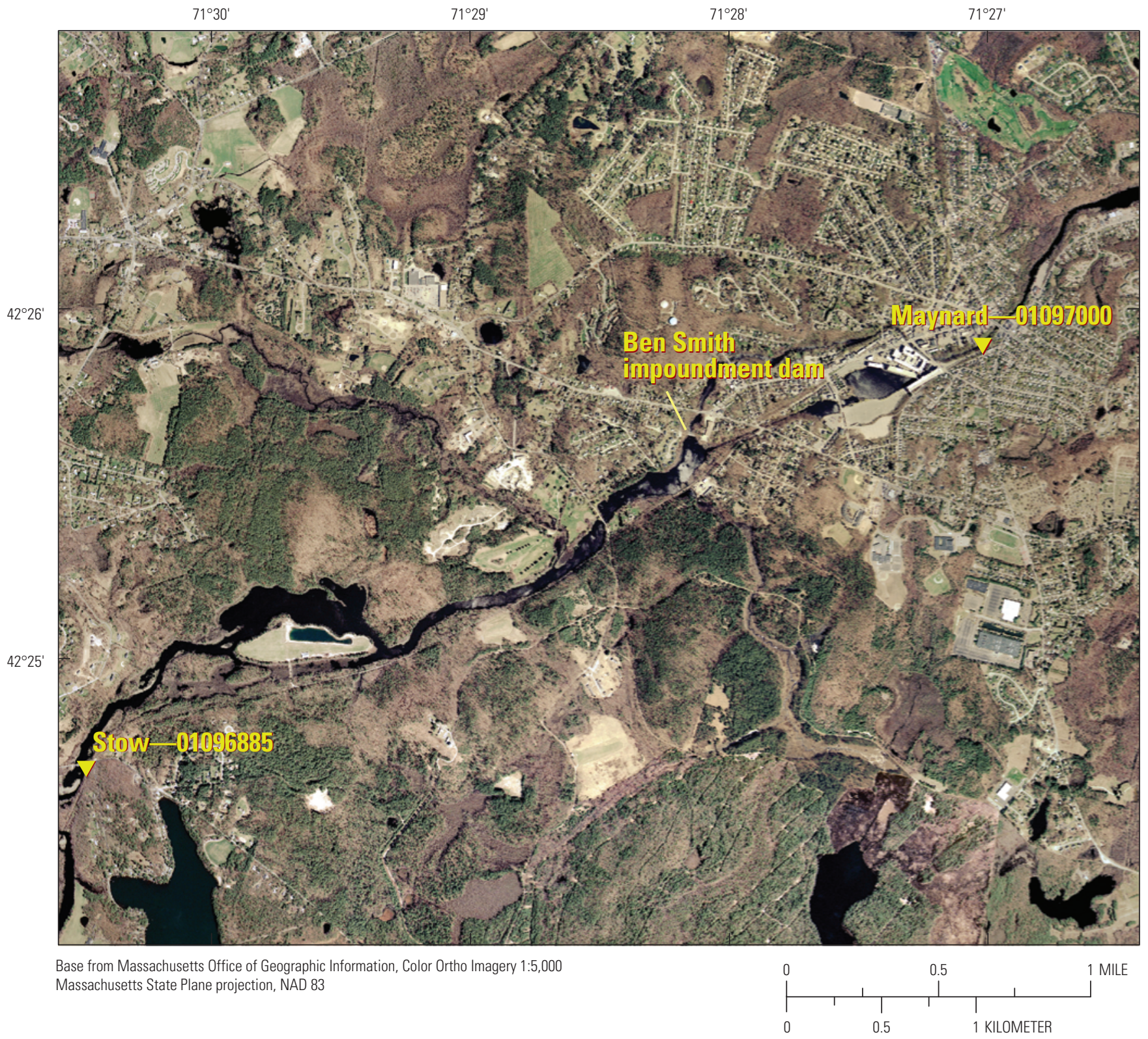

Figure 3. Orthophotograph map identifying the locations of water-quality-monitoring stations Stow (01096885) and Maynard (01097000), upstream and downstream from the Ben Smith impoundment on the Assabet River, Massachusetts. See table 1 for full station names. Modified from Zimmerman and Savoie (2013, fig. 3). 


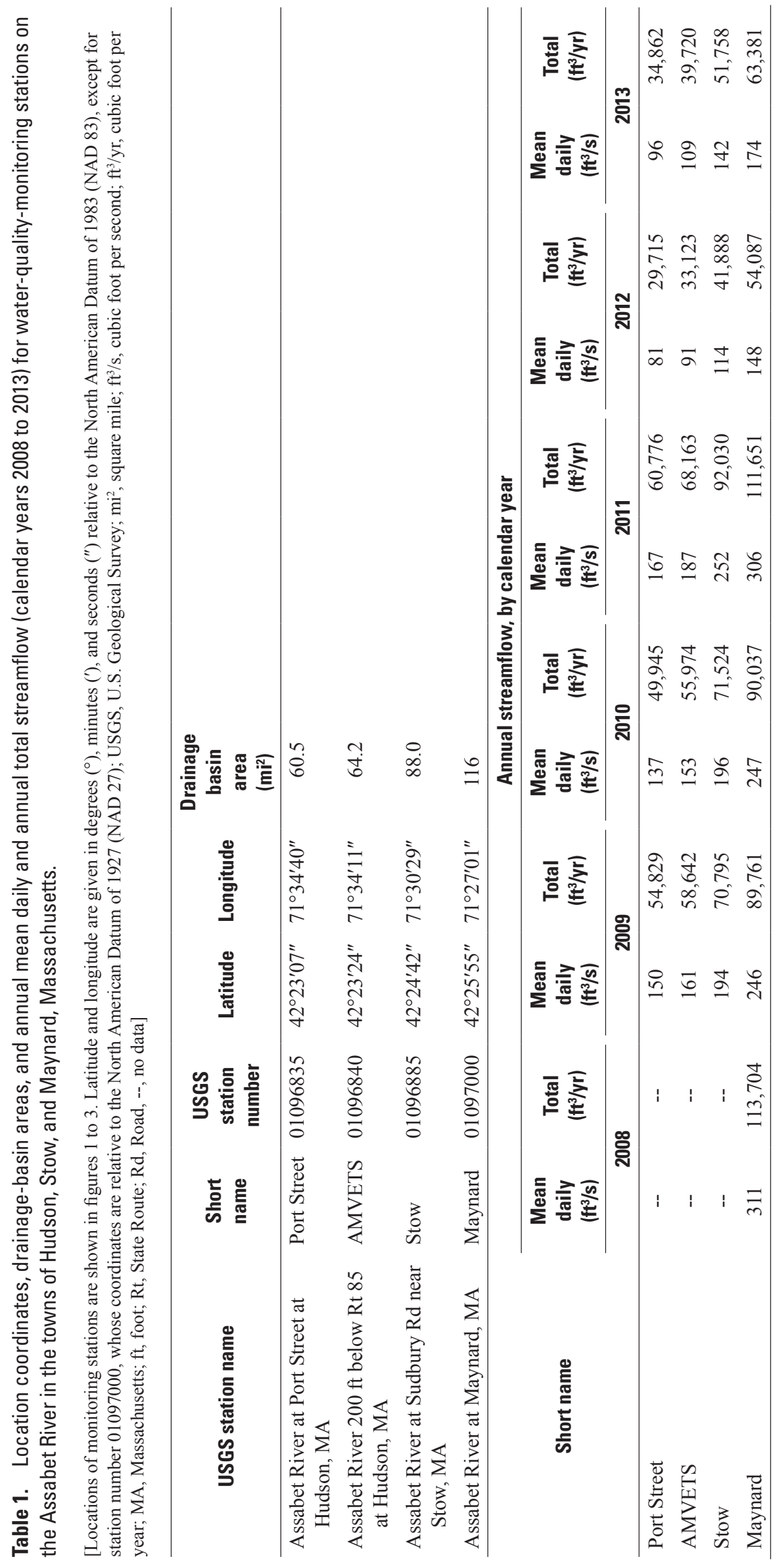




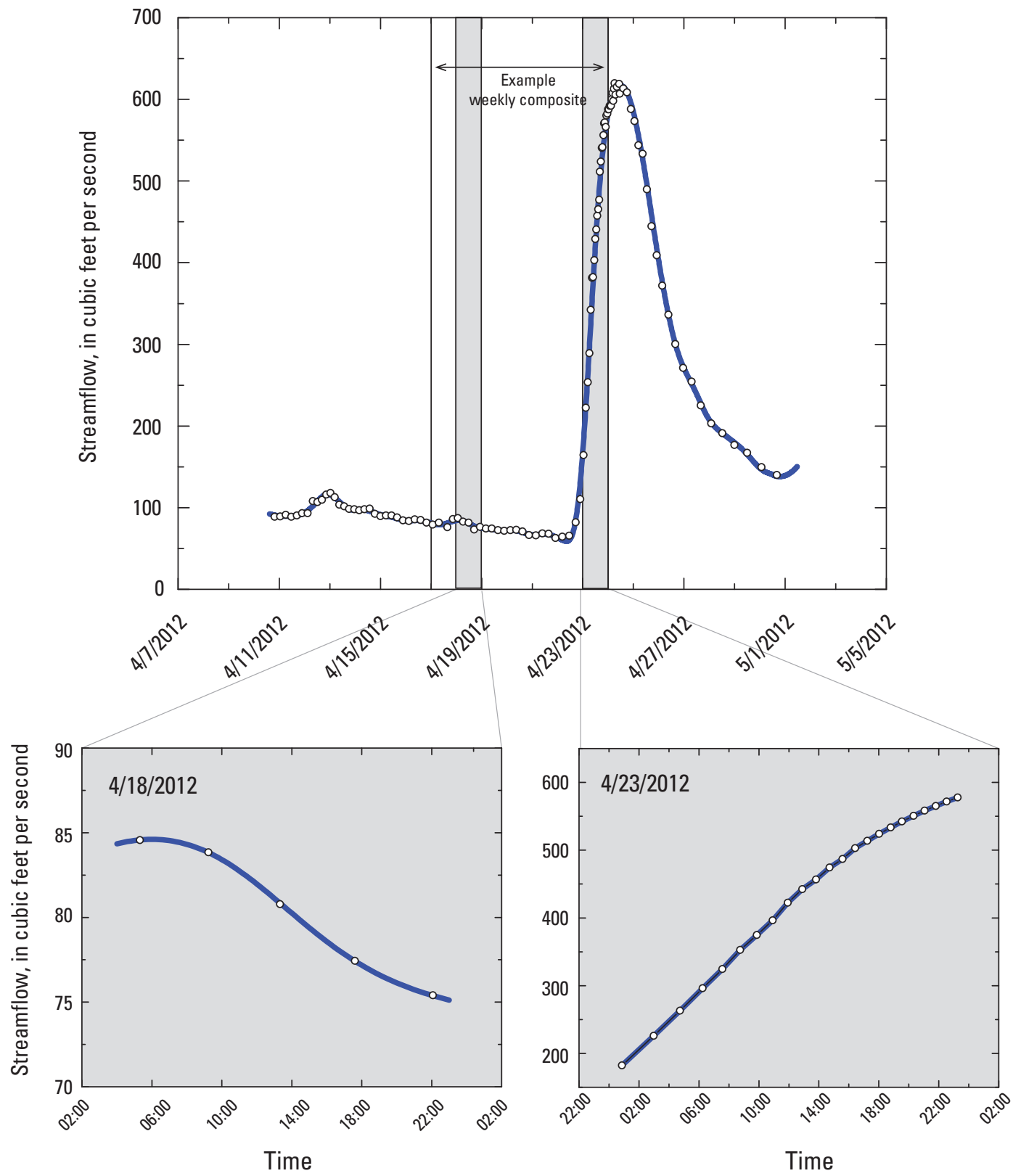

\section{EXPLANATION}

- Streamflow

- Automated sample collection

Figure 4. Streamflow and sample-collection rate, demonstrating the flow-proportional sampling method. 
The first aliquot, the TP sample, was pumped into a 3.8-liter (L) polyethylene bottle previously acidified with $10 \mathrm{~mL}$ of sulfuric acid. The second aliquot, the orthoP sample, was pumped into a second bottle, which was modified so that the water sample could be completely pumped into a refrigerator by a peristaltic pump. Inside the refrigerator, the tubing connected to an inline polysulfone capsule filter with a pore size of 0.45 micrometer, polyester reinforcement, and an effective filtration area of 20 square centimeters. After passing through the filter, the sample entered a 9-L polyethylene storage bottle.

In the event that the week's streamflow was underestimated and more than 32 samples were automatically collected, a second 3.8-L acidified TP bottle collected any additional TP samples; the 9-L orthoP storage bottle had ample capacity for additional samples. If the total weekly streamflow was overestimated, fewer than $32 \mathrm{TP}$ and orthoP samples were collected, but the sample numbers were nevertheless collected proportional to flow.

The weekly composite samples were processed and shipped to the USGS National Water Quality Laboratory (NWQL) in Denver, Colorado, for analysis of TP and orthoP (Fishman, 1993; U.S. Environmental Protection Agency, 1993). Additional information about the study design is described in Zimmerman and Savoie (2013).

\section{Quality-Control Samples}

Quality-control samples were collected throughout the study period to confirm that the automated sampling system collected representative samples. Equal-width increment (EWI) samples and weighted-bottle point samples from bridges were collected concurrently with inside grab samples (IGSs) collected by the automated sampler. Details about EWI sampling methods are described in the USGS "National Field Manual for the Collection of Water-Quality Data" (U.S. Geological Survey, 2006). The TP and orthoP concentrations in the EWI and weighted-bottle point samples were compared to concentrations in IGS collected by the automated sampler to verify that the automated sampler was collecting representative river-water samples. Other quality-control samples included source solution blank samples and replicate (split-composite) samples. Source solution blank samples were collected to ensure that the laboratory-grade deionized water used for the weekly rinsing of sample bottles and cleaning of the sample-collection bottles did not contain detectable concentrations of TP and orthoP, and sample replicates were collected to estimate variability in the sample processing (splitting and filtering) (Mueller and others, 2015).

Source solution blank samples, replicate (splitcomposite) samples, and concurrent (1) IGSs and EWI samples and (2) IGSs and weighted-bottle point samples are shown in Savoie (2016). Total phosphorus and orthoP were not detected in any of the rinse-water blank samples, and the median relative percent differences (RPDs) for the replicate samples were about 2 percent or less at all four locations. Concurrent IGS-weighted-bottle point and IGS-EWI samples were collected during periods of low-, average-, and highstreamflow conditions. The IGSs had good agreement with the weighted-bottle point and EWI samples most of the time, with RPDs within 20 percent. Two exceptions were at the Maynard monitoring station on October 1, 2008, and at the Port Street monitoring station on April 1, 2014. The reason for the dissimilar concurrent samples at the Maynard monitoring station (RPD value of about 35 percent) at the beginning of the study is unknown; however, subsequent concurrent samples had better agreement (11.4 percent or less). The dissimilar concurrent samples at the Port Street monitoring station (RPD value of 186 percent) alerted us to potential sediment buildup at the intake of the automated sampler; because of the sediment buildup, total phosphorus data for the last month at the Port Street monitoring station were estimated by using data from the AMVETS monitoring station. Overall, the qualitycontrol-sampling results indicate that the automated samplers were collecting representative samples from these well-mixed sections of the river.

\section{Load Calculations}

Loads represent the mass of substance (phosphorus in this case) that passes the sampling location in a given period of time and incorporate the variability of concentration and the hydrologic system during the period of sample collection. Weekly composite concentrations of TP and orthoP were used to estimate daily loads of TP and orthoP at each waterquality-monitoring station by multiplying the concentration (in milligrams per liter) by the daily streamflow (in cubic feet per second) for each day during the composited week and converting the resulting value to units of kilograms per day.

At times during the 5-year study, composite samples were not available, and concentrations were estimated - for example, when the sample tubing froze or became clogged with sediment, when the stream level dropped below the sampler intake, or when human errors prevented the collection of a week's composite sample. During the 290 -week sampling period, concentrations were estimated for 20 weeks of TP and 18 weeks of orthoP at the Port Street monitoring station, for 11 weeks of TP and 19 weeks of orthoP at the AMVETS monitoring station, for 14 weeks of TP and 17 weeks of orthoP at the Stow monitoring station, and for 17 weeks of TP and 19 weeks of orthoP at the Maynard monitoring station. In situations with missing data, composite-sample concentrations were estimated by using either values from before and after the missing-data event at the station or concentration data from nearby upstream or downstream stations.

The USGS NWQL method detection limit (MDL) for TP and orthoP is $0.004 \mathrm{mg} / \mathrm{L}$. In cases where the reported orthoP results were less than the MDL, the actual laboratory result was used as the best estimate of concentration if the value fell between 0.002 and $0.004 \mathrm{mg} / \mathrm{L}$; if the laboratory value 
was less than $0.002 \mathrm{mg} / \mathrm{L}$, then $0.002 \mathrm{mg} / \mathrm{L}$ was used as the best estimate. The cases when less than MDL orthoP values were estimated were only 1 percent at the Port Street monitoring station, 4 percent at the AMVETS monitoring station, 8 percent at the Stow monitoring station, and 7 percent at the Maynard monitoring station. The orthoP values estimated to be less than the MDL are not reported; only " $<0.004 \mathrm{mg} / \mathrm{L}$ " is given in the data tables in Savoie (2016).

\section{Changes in Phosphorus Concentrations and Loads}

This section presents data on instream changes in TP and orthoP concentrations and loads following decreases in TP concentrations in effluent from three WWTPs in the Assabet River. Changes in TP and orthoP concentrations and loads and effects of seasonal variations were examined at four monitoring stations downstream from the WWTPs following the implementation of the TP TMDL. Concentrations of $\mathrm{TP}$ and orthoP in the Assabet River were measured in flowproportional composite samples and, consequently, represent flow-weighted average concentrations in the river during weeklong sampling periods. The monitoring stations were located upstream and downstream of two large impoundments, and the effects of impoundments on concentrations and loads also were investigated.

\section{Phosphorus Concentrations}

Reductions in TP concentrations were observed in the WWTP effluent and at the instream monitoring stations downstream from the WWTPs (Savoie, 2016). The USGS used TP concentration data from 24-hour composite samples and daily effluent volumes obtained from the three WWTPs to estimate daily TP loads in WWTP effluent; concentration data were typically from samples collected weekly or at times more frequently (written commun., Christopher Pratt, Westborough WWTP, and Mark Concheri, Hudson WWTP, May 12, 2014; and Harry Butland, Marlborough-Westerly WWTP, August 20, 2014). The TP concentrations in WWTP effluent were disaggregated to daily TP concentrations and estimated when not measured. Concentrations were estimated on days when the WWTPs did not measure TP. When missing daily concentrations were estimated, time-adjacent concentrations were used; if the adjacent concentrations differed, they were averaged. TP loads in WWTP effluent were calculated by multiplying concentrations of TP (in milligrams per liter) by the effluent discharge volume (in million gallons per day) and converted to units of kilograms per day (Savoie, 2016). OrthoP loads in WWTP effluent were not calculated because of incomplete data for the period of record.

Patterns of instream concentrations of TP at the Port Street and AMVETS monitoring stations in weekly flow-proportional composite samples and the combined daily average concentrations in effluent from the two upstream WWTPs are shown for the entire study period in figure 5 . Similar patterns were observed in concentrations in weekly flow-proportional composite samples from the Stow and Maynard monitoring stations, which were downstream from all three WWTPs (fig. 6). Concentrations were highly variable; however, decreases in both TP effluent from the WWTPs and TP concentrations measured at the AMVETS, Stow, and Maynard monitoring stations were observed in the data for the period following implementation of the TMDL-mandated WWTP upgrades in March 2012. OrthoP (the filtered sample, or dissolved form of phosphorus) concentrations at the instream monitoring stations also decreased following WWTP upgrades, though the changes were not as great as the changes in TP concentrations (figs. 7 and 8). In addition to the longterm patterns observed across the entire study, some large, rapid, short-term decreases in TP and orthoP concentrations were associated with periods of increased streamflow-for example, during March and April 2010, March and April 2011, and December 2011.

The annual distributions of estimated daily total phosphorus concentrations in both the WWTP discharge effluent (fig. 9) and instream at the monitoring stations (fig. 10) are best represented by annual box plots that show the median, 10-percent, interquartile, and 90-percent concentrations. For this analysis, the median values were taken as the best overall indicators of year-to-year changes; the 10-percent, interquartile, and 90-percent concentrations are an indication of the variability in the data. Median and mean TP and orthoP concentrations and loads in both the WWTP discharge effluent and in the instream monitoring stations are summarized in tables 2 and 3.

Changes in annual median TP concentrations reported by the WWTPs align with the dates in which the plants were upgraded to comply with TMDL-mandated reductions (fig. 9 and table 2). Although the individual WWTPs became compliant with the TMDL at different times, all of the WWTPs were compliant by the end of March 2012. The annual median TP concentration for the Hudson WWTP (compliant October 2009) decreased from 0.74 milligrams per liter $(\mathrm{mg} / \mathrm{L})$ in 2009 to $0.12 \mathrm{mg} / \mathrm{L}$ in 2010 and remained at or below $0.10 \mathrm{mg} / \mathrm{L}$ through 2013. The annual median TP concentration for the Marlborough-Westerly WWTP (compliant January 2012) decreased from 0.47 in 2009 to 0.42 to $0.40 \mathrm{mg} / \mathrm{L}$ in 2010 and 2011, respectively, to $0.08 \mathrm{mg} / \mathrm{L}$ in 2012 and 2013. The annual median TP concentration for the Westborough WWTP (compliant March 2012) ranged from 0.47 to $0.59 \mathrm{mg} / \mathrm{L}$ in 2009 to 2011 , decreased to $0.09 \mathrm{mg} / \mathrm{L}$ in 2012, and further decreased to $0.06 \mathrm{mg} / \mathrm{L}$ in 2013 . Reductions in annual median TP concentrations in discharge at all three WWTPs represent reductions of more than 80 percent relative to before-TMDL implementation concentrations. The Westborough WWTP is the largest of the three WWTPs, and the annual discharge from the Westborough plant contributed 30 to 65 percent of the total annual discharge for all three plants during the study period. 


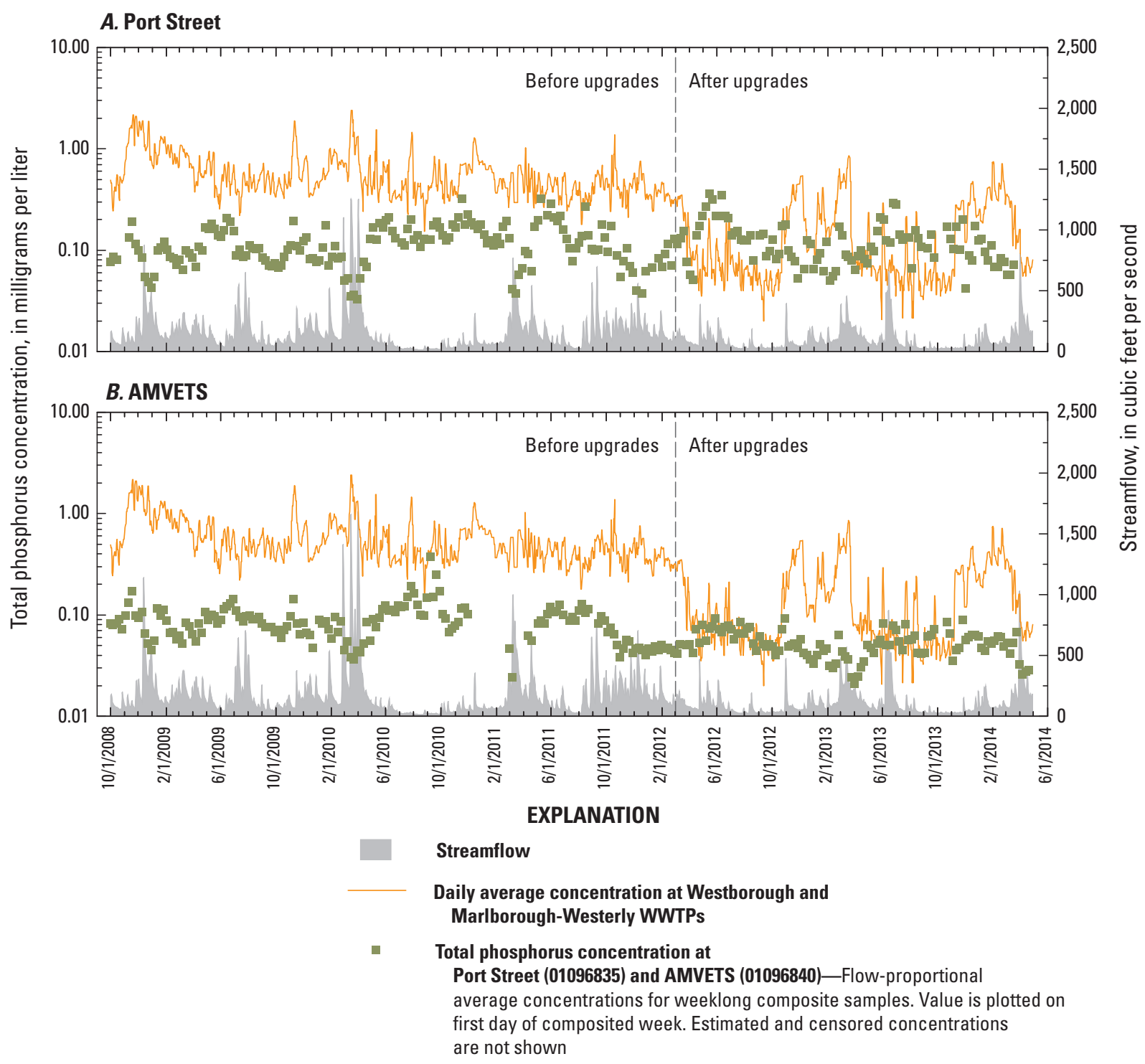

Figure 5. Streamflow and total phosphorus concentrations at the $A$, Port Street (01096835) and B, AMVETS (01096840) water-quality-monitoring stations, and daily average total phosphorus concentration in effluent from Westborough and Marlborough-Westerly wastewater-treatment plants (WWTPs), in the Assabet River, Massachusetts, 2008-2014. See table 1 for full station names. 


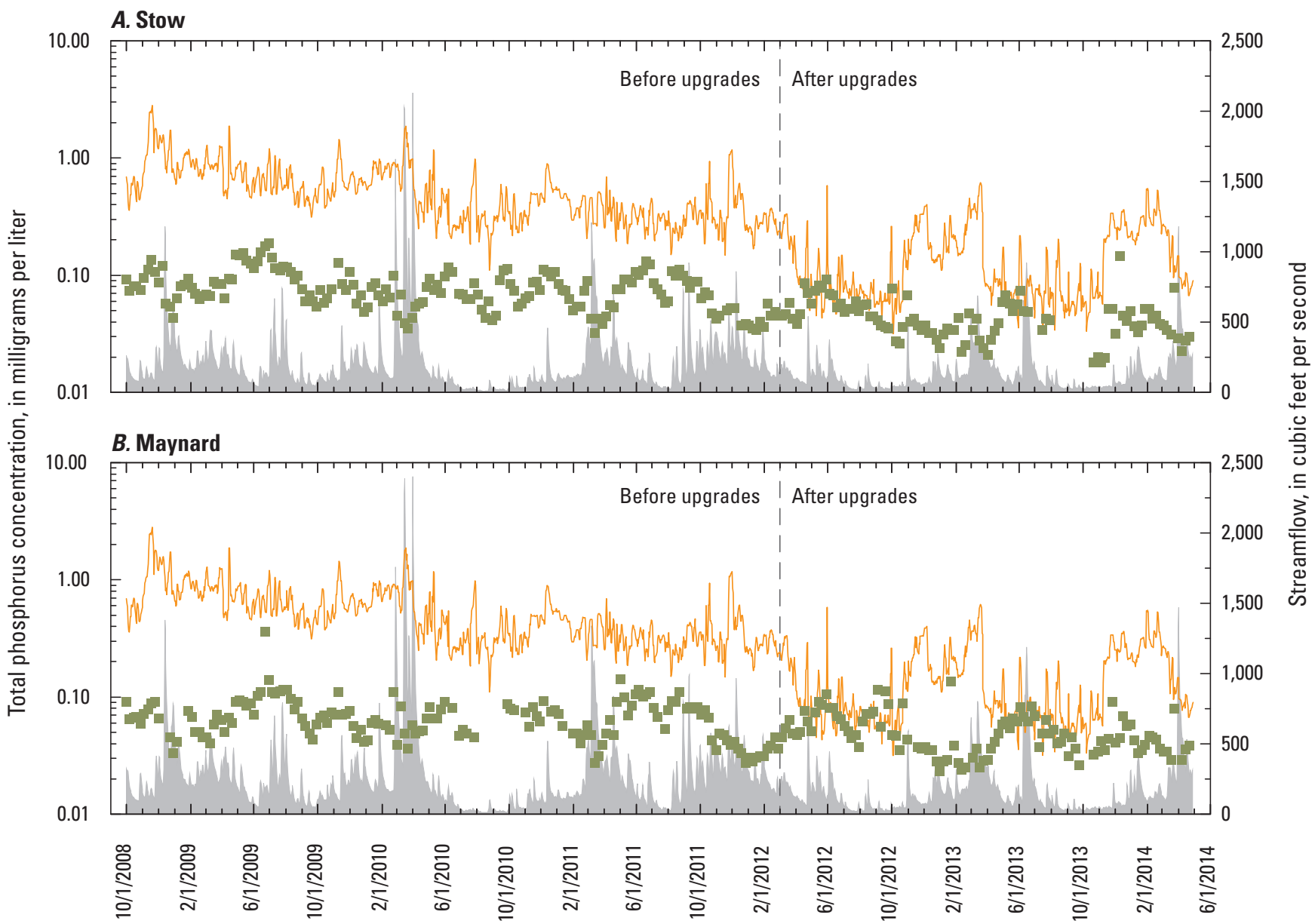

\section{EXPLANATION}

Streamflow

Daily average concentration at Westborough, Marlborough-Westerly, and Hudson WWTPs

- Total phosphorus concentration at Stow (01096885) and Maynard (01097000)—Flow-proportional average concentrations for weeklong composite samples. Value is plotted on first day of composited week. Estimated and censored concentrations are not shown

Figure 6. Streamflow and total phosphorus concentrations at the $A$, Stow (01096885) and $B$, Maynard (01097000) water-qualitymonitoring stations, and daily average total phosphorus concentration in effluent from Westborough, Marlborough-Westerly, and Hudson wastewater-treatment plants (WWTPs), in the Assabet River, Massachusetts, 2008-2014. See table 1 for full station names. 


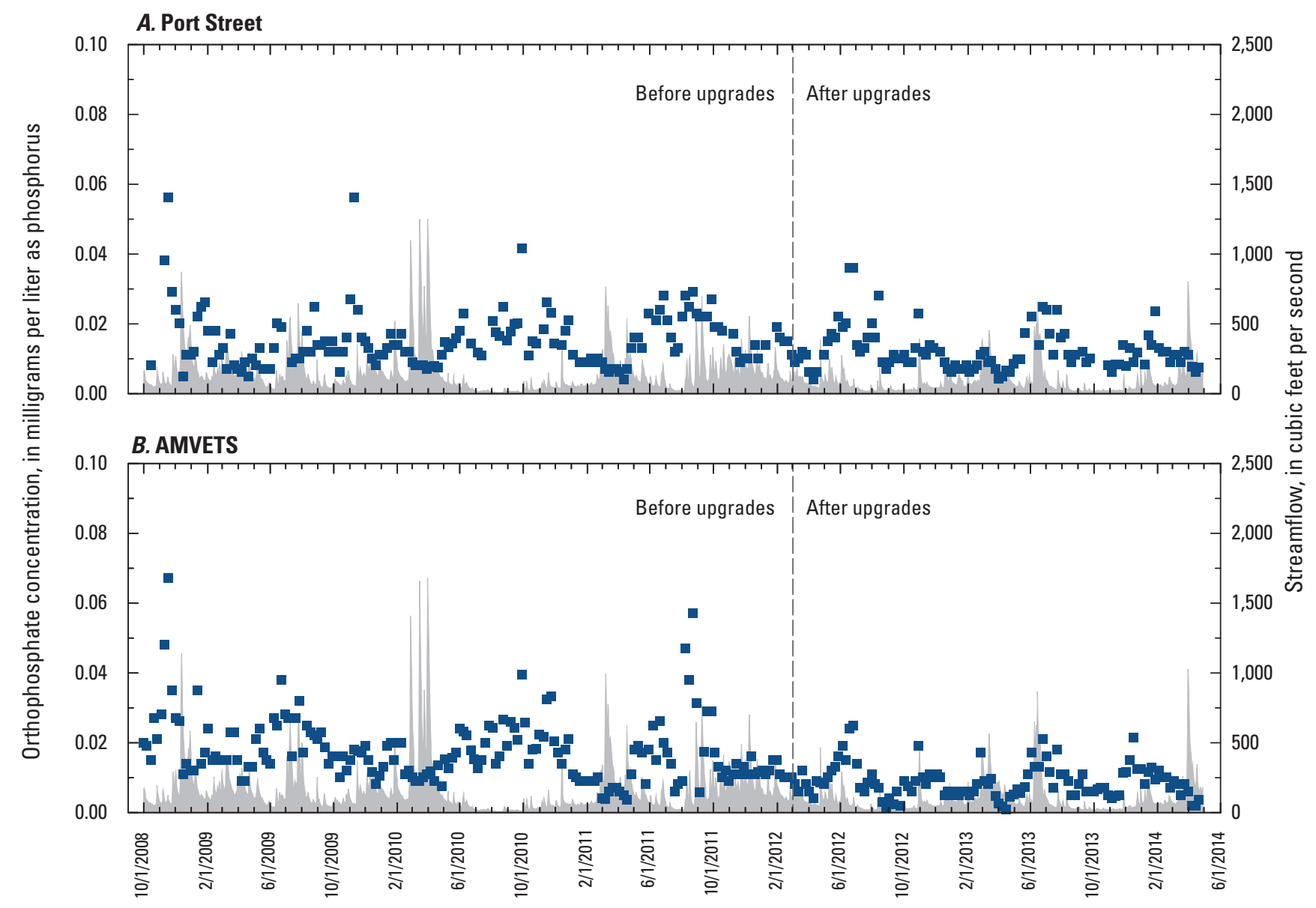

EXPLANATION

Streamflow

- Orthophosphate concentration at

Port Street (01096835) and AMVETS (01096840)—Flow-proportional

average concentrations for weeklong composite samples. Value is plotted on first day of composited week

Figure 7. Streamflow and orthophosphate concentrations at the $A$, Port Street (01096835) and B, AMVETS (01096840) waterquality-monitoring stations on the Assabet River, Massachusetts, 2008-2014. See table 1 for full station names. 


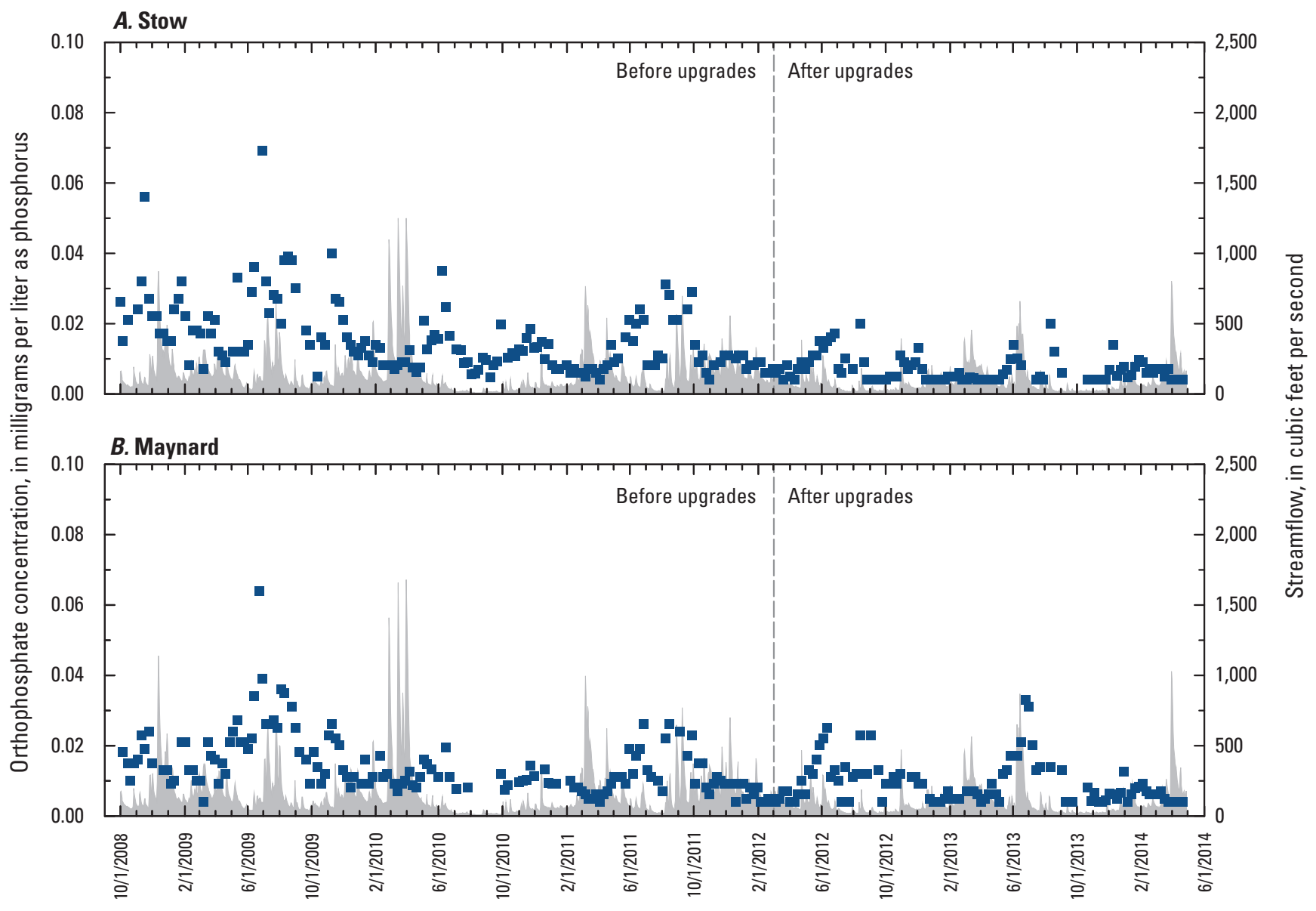

\section{EXPLANATION}

Streamflow

- Orthophosphate concentration at

Stow (01096885) and Maynard (01097000)-Flow-proportional

average concentrations for weeklong composite samples. Value is plotted on first day of composited week. Estimated and censored concentrations are not shown

Figure 8. Streamflow and orthophosphate concentrations at the $A$, Stow (01096885) and $B$, Maynard (01097000) water-qualitymonitoring stations on the Assabet River, Massachusetts, 2008-2014. See table 1 for full station names. 


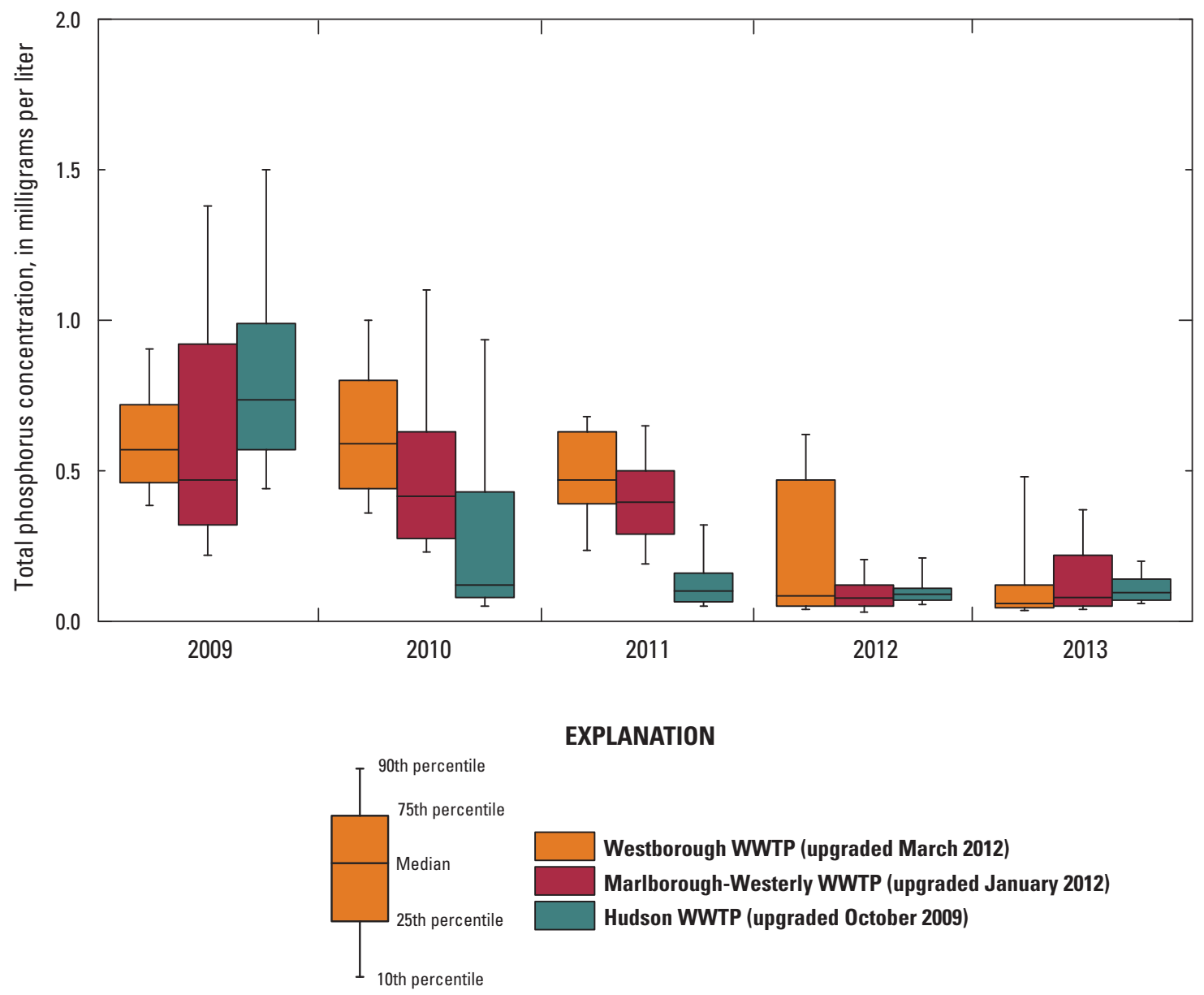

Figure 9. Annual distributions of estimated daily concentrations of total phosphorus in wastewater-treatmentplant (WWTP) effluent to the Assabet River, Massachusetts, 2009-2013.

Annual median TP and orthoP concentrations at three of the four instream monitoring stations generally decreased following complete implementation of the WWTP upgrades in 2012 (fig. 10 and table 3). Annual median TP concentrations decreased by about 38 to 50 percent at the AMVETS, Stow, and Maynard monitoring stations during the study period. The annual median TP concentration at the AMVETS monitoring station ranged from 0.07 to $0.09 \mathrm{mg} / \mathrm{L}$ from 2009 to 2011 and decreased to $0.05 \mathrm{mg} / \mathrm{L}$ in 2012 and 2013. The annual median TP concentration at the Stow monitoring station ranged from 0.07 to $0.08 \mathrm{mg} / \mathrm{L}$ from 2009 to 2011 and decreased to $0.04 \mathrm{mg} / \mathrm{L}$ in 2012 and 2013. The annual median TP concentration at the Maynard monitoring station ranged from 0.06 to $0.07 \mathrm{mg} / \mathrm{L}$ from 2009 to 2011 and decreased to $0.05 \mathrm{mg} / \mathrm{L}$ in 2012 and to $0.04 \mathrm{mg} / \mathrm{L}$ in 2013. Decreases in annual median orthoP concentrations were observed throughout the study period at the AMVETS, Stow, and Maynard monitoring stations, with annual median orthoP concentrations of about 0.017 to $0.019 \mathrm{mg} / \mathrm{L}$ in 2009 that decreased to about 0.004 to $0.007 \mathrm{mg} / \mathrm{L}$ in 2013.
In contrast to annual median TP concentrations at the other three instream monitoring stations, the concentration at the Port Street monitoring station did not decrease but remained at 0.10 to $0.13 \mathrm{mg} / \mathrm{L}$ during the entire study period (fig. $10 \mathrm{~A}$ and table 3 ). This difference between TP concentrations at the Port Street monitoring station and the other stations may be related to the location of the station, which was in a slow-moving section of the river at the upstream end of the Hudson impoundment. The monitoring system at the Port Street monitoring station may have been in a position to record seasonal and (or) flow-related resuspension of particulate phosphorus that accumulated in the bed sediments. TP concentrations and the proportion of TP that was particulate (the difference between TP and orthoP) were typically higher at the Port Street monitoring station than at the other stations downstream, especially after 2010. Downstream from the Port Street monitoring station, particulate matter is likely to rapidly settle in the Hudson impoundment, and particulate phosphorus constituted consistently smaller fractions of TP at the AMVETS monitoring station than at the Port Street 

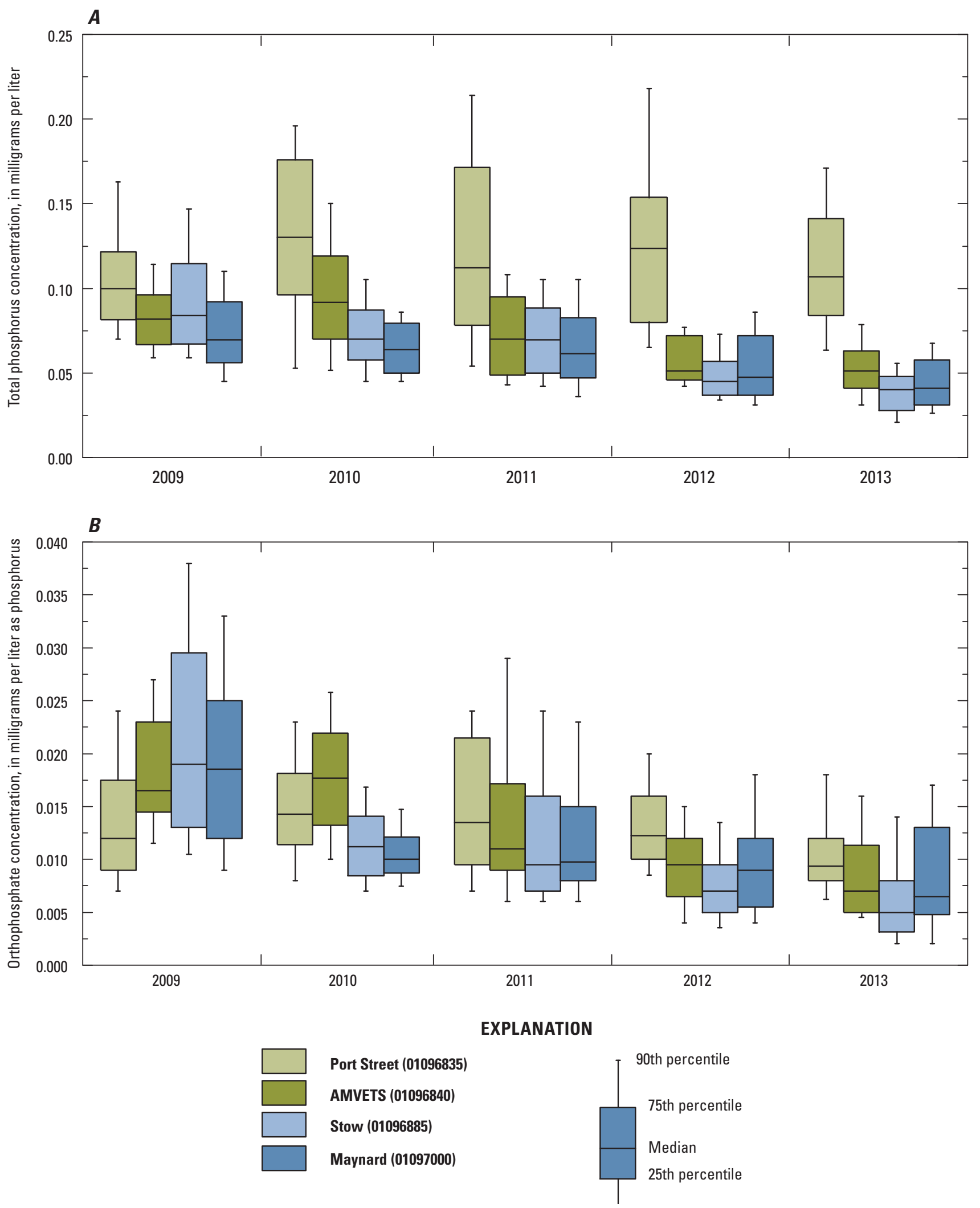

Figure 10. Annual distributions of estimated daily concentrations of $A$, total phosphorus and $B$, orthophosphate in weekly flowproportional composite samples from four water-quality-monitoring stations on the Assabet River, Massachusetts, 2009-2013. See table 1 for full station names. 
Table 2. Median and mean flow and total phosphorus concentrations and loads at wastewater-treatment plants in the towns of Westborough, Marlborough, and Hudson on the Assabet River, Massachusetts, 2009 through 2013.

[Locations of wastewater-treatment plants (WWTPs) are shown in figure 1. Results are for calendar year. Concentration values are based on estimated daily concentrations used for loads calculations. Mgal/d, million gallons per day; mg/L, milligram per liter; kg/d, kilogram per day; --, data not included]

\begin{tabular}{|c|c|c|c|c|c|c|}
\hline \multirow{3}{*}{ Year } & & & \multicolumn{4}{|c|}{ Total phosphorus } \\
\hline & \multicolumn{2}{|c|}{$\begin{array}{c}\text { Flow } \\
\text { (Mgal/d) }\end{array}$} & \multicolumn{2}{|c|}{$\begin{array}{c}\text { Concentration } \\
\text { (mg/L) }\end{array}$} & \multicolumn{2}{|c|}{$\begin{array}{l}\text { Load } \\
(\mathrm{kg} / \mathrm{d})\end{array}$} \\
\hline & Median & Mean & Median & Mean & Median & Mean \\
\hline \multicolumn{7}{|c|}{ Westborough WWTP } \\
\hline 2009 & 6.2 & 6.4 & 0.57 & 0.62 & 13.9 & 14.9 \\
\hline 2010 & 5.5 & 6.2 & 0.59 & 0.65 & 12.3 & 15.6 \\
\hline 2011 & 6.1 & 6.4 & 0.47 & 0.48 & 11.9 & 11.5 \\
\hline 2012 & 4.9 & 5.0 & 0.09 & 0.23 & 1.6 & 4.4 \\
\hline 2013 & 5.1 & 5.5 & 0.06 & 0.17 & 1.3 & 3.7 \\
\hline \multicolumn{7}{|c|}{ Marlborough-Westerly WWTP } \\
\hline 2009 & 2.5 & 2.6 & 0.47 & 0.66 & 4.5 & 6.7 \\
\hline 2010 & 2.1 & 2.3 & 0.42 & 0.58 & 3.3 & 6.3 \\
\hline 2011 & 2.7 & 2.8 & 0.40 & 0.42 & 3.6 & 4.5 \\
\hline 2012 & 1.9 & 1.9 & 0.08 & 0.11 & 0.6 & 0.8 \\
\hline 2013 & 1.8 & 1.9 & 0.08 & 0.15 & 0.6 & 1.2 \\
\hline \multicolumn{7}{|c|}{ Hudson WWTP } \\
\hline 2009 & 2.4 & 2.4 & 0.74 & 0.86 & 6.9 & 8.0 \\
\hline 2010 & 1.7 & 2.0 & 0.12 & 0.31 & 0.7 & 2.9 \\
\hline 2011 & 2.1 & 2.2 & 0.10 & 0.18 & 0.7 & 1.6 \\
\hline 2012 & 1.6 & 1.7 & 0.09 & 0.12 & 0.5 & 0.8 \\
\hline 2013 & 1.6 & 1.7 & 0.10 & 0.12 & 0.6 & 0.8 \\
\hline \multicolumn{7}{|c|}{ Westborough and Marlborough WWTPs } \\
\hline 2009 & -- & -- & -- & -- & 18.4 & 21.7 \\
\hline 2010 & -- & -- & -- & -- & 15.6 & 21.8 \\
\hline 2011 & -- & -- & -- & -- & 15.5 & 16.0 \\
\hline 2012 & -- & -- & -- & -- & 2.2 & 5.2 \\
\hline 2013 & -- & -- & -- & -- & 1.9 & 4.9 \\
\hline \multicolumn{7}{|c|}{ Westborough, Marlborough, and Hudson WWTPs } \\
\hline 2009 & -- & -- & -- & -- & 25.3 & 29.7 \\
\hline 2010 & -- & -- & -- & -- & 16.4 & 24.7 \\
\hline 2011 & -- & -- & -- & -- & 16.2 & 17.6 \\
\hline 2012 & -- & -- & -- & -- & 2.7 & 5.9 \\
\hline 2013 & -- & -- & -- & -- & 2.5 & 5.7 \\
\hline
\end{tabular}

monitoring station. Annual median orthoP concentrations at the Port Street monitoring station also remained similar during the entire study, at 0.011 to $0.015 \mathrm{mg} / \mathrm{L}$, further suggesting that concentrations at the Port Street monitoring station were behaving differently than concentrations at the downstream stations.
Relations of concentration to streamflow are commonly used to characterize phosphorus in streams in terms of its origin from point sources such as WWTPs. Instream phosphorus predominantly from WWTPs is diluted by inflows of runoff and (or) groundwater discharge so that concentrations are inversely related to flow. In contrast, instream phosphorus predominantly from overland runoff, such as agricultural or stormwater runoff, increases during high flows, resulting in higher concentrations during high flows. The TP and orthoP concentration data collected during this study are not ideal for analysis of source contributions because the data represent average concentrations during the weeklong sampling periods. The composite concentration data are also flow-weighted averages, which means that for sampling periods when flow varied, the data are more representative of concentrations during the parts of the week with higher flow than the parts with lower flow. This use of flow-weighted averages makes the data well suited to the calculation of instream loads, because more of the load is carried by the river during times of higher flow than during times of lower flow, but the method makes the data less suited for analysis of relations between streamflow and concentration.

During most of these weeklong periods, flows changed in response to storms of short duration (hours or days). Consequently, relations between concentration and flow in the stream that might be apparent in discrete samples are likely to be obscured by the averaging that is inherent in the composite samples. Nevertheless, some relations are apparent between concentration and flow, where flow is the average of daily mean flows for the seven days of the sampling period. Inverse relations between TP concentration and flow are most clearly apparent at the AMVETS monitoring station both before (2008-11) and after (2012-14) WWTP upgrades and at the Port Street and Stow monitoring stations before the WWTP upgrades (fig. 11). Inverse relations are consistent with the previous findings of WWTP effluent as the primary source of instream phosphorus in the Assabet River except during highflow wet-weather events (ENSR International, 2001; Massachusetts Department of Environmental Protection, 2004). The Port Street, AMVETS, and Stow monitoring stations are closer to the WWTPs than the Maynard monitoring station, so inverse relations with flow are more apparent at these stations than at the Maynard monitoring station, which is downstream from a large tributary (Elizabeth Brook, also known as Assabet Brook; fig. 1) and downtown Maynard.

\section{Streamflow During the Study Period}

Streamflow during the study period (October 2008 through April 2014) was higher than average, in terms of annual mean flow, during the initial years of the study and near or below average during the final years of the study, based on flow at the long-term gaging station at Maynard (01097000, period of record 1942 to present; fig. 12). Annual mean flows at the Maynard monitoring station in calendar years 2009, 
Table 3. Median and mean flow and total phosphorus and orthophosphate concentrations and loads at water-quality-monitoring stations on the Assabet River in the towns of Hudson, Stow, and Maynard, Massachusetts, 2009 through 2013.

[Locations of instream monitoring stations are shown in figures 1 to 3. Full station names and numbers are listed in table 1. Results are for calendar year. Concentration values include estimated concentrations for periods of missing data. $\mathrm{ft}^{3} / \mathrm{s}$, cubic foot per second; $\mathrm{mg} / \mathrm{L}$, milligram per liter; $\mathrm{kg} / \mathrm{d}$, kilogram per day]

\begin{tabular}{|c|c|c|c|c|c|c|c|c|c|c|}
\hline \multirow{3}{*}{ Year } & \multirow{2}{*}{\multicolumn{2}{|c|}{$\begin{array}{l}\text { Flow } \\
\left(\mathrm{ft}^{3} / \mathrm{s}\right)\end{array}$}} & \multicolumn{4}{|c|}{ Total phosphorus } & \multicolumn{4}{|c|}{ Orthophosphate } \\
\hline & & & \multicolumn{2}{|c|}{$\begin{array}{l}\text { Concentration } \\
(\mathrm{mg} / \mathrm{L})\end{array}$} & \multicolumn{2}{|c|}{$\begin{array}{l}\text { Load } \\
\text { (kg/d) }\end{array}$} & \multicolumn{2}{|c|}{$\begin{array}{l}\text { Concentration } \\
\text { (mg/L) }\end{array}$} & \multicolumn{2}{|c|}{$\begin{array}{l}\text { Load } \\
(\mathrm{kg} / \mathrm{d})\end{array}$} \\
\hline & Median & Mean & Median & Mean & Median & Mean & Median & Mean & Median & Mean \\
\hline \multicolumn{11}{|c|}{ Port Street } \\
\hline 2009 & 131 & 150 & 0.100 & 0.107 & 32.9 & 37.3 & 0.012 & 0.014 & 4.2 & 4.9 \\
\hline 2010 & 62 & 137 & 0.130 & 0.135 & 22.4 & 28.5 & 0.014 & 0.016 & 2.6 & 3.8 \\
\hline 2011 & 141 & 167 & 0.116 & 0.129 & 35.8 & 45.2 & 0.014 & 0.015 & 4.5 & 5.8 \\
\hline 2012 & 65 & 81 & 0.124 & 0.134 & 17.8 & 28.0 & 0.012 & 0.014 & 2.2 & 2.9 \\
\hline 2013 & 63 & 96 & 0.107 & 0.119 & 13.9 & 28.1 & 0.009 & 0.011 & 1.4 & 2.8 \\
\hline \multicolumn{11}{|c|}{ AMVETS } \\
\hline 2009 & 135 & 161 & 0.082 & 0.084 & 27.1 & 32.4 & 0.017 & 0.018 & 6.0 & 7.4 \\
\hline 2010 & 66 & 153 & 0.092 & 0.102 & 14.9 & 24.7 & 0.018 & 0.018 & 2.8 & 5.0 \\
\hline 2011 & 149 & 187 & 0.070 & 0.074 & 23.3 & 29.5 & 0.011 & 0.015 & 4.6 & 6.5 \\
\hline 2012 & 69.5 & 91 & 0.051 & 0.057 & 9.7 & 12.5 & 0.010 & 0.010 & 1.7 & 2.4 \\
\hline 2013 & 69 & 109 & 0.051 & 0.053 & 7.4 & 13.0 & 0.007 & 0.009 & 1.1 & 2.6 \\
\hline \multicolumn{11}{|c|}{ Stow } \\
\hline 2009 & 170 & 194 & 0.084 & 0.095 & 38.1 & 44.4 & 0.019 & 0.022 & 8.7 & 10.4 \\
\hline 2010 & 92 & 196 & 0.070 & 0.073 & 18.4 & 30.2 & 0.011 & 0.012 & 2.9 & 5.0 \\
\hline 2011 & 209 & 252 & 0.070 & 0.071 & 30.8 & 39.8 & 0.010 & 0.012 & 5.5 & 7.2 \\
\hline 2012 & 91.5 & 114 & 0.045 & 0.049 & 10.5 & 14.4 & 0.007 & 0.008 & 1.7 & 2.4 \\
\hline 2013 & 95 & 142 & 0.040 & 0.040 & 9.4 & 14.3 & 0.004 & 0.005 & 1.1 & 2.0 \\
\hline \multicolumn{11}{|c|}{ Maynard } \\
\hline 2009 & 227 & 246 & 0.070 & 0.079 & 37.7 & 46.4 & 0.019 & 0.020 & 9.1 & 11.2 \\
\hline 2010 & 127 & 247 & 0.064 & 0.065 & 21.5 & 37.6 & 0.010 & 0.011 & 3.8 & 6.3 \\
\hline 2011 & 276 & 306 & 0.062 & 0.066 & 37.3 & 45.0 & 0.010 & 0.012 & 6.5 & 8.3 \\
\hline 2012 & 121.5 & 148 & 0.048 & 0.055 & 14.6 & 18.5 & 0.009 & 0.010 & 2.3 & 3.5 \\
\hline 2013 & 107 & 174 & 0.041 & 0.046 & 11.3 & 20.0 & 0.007 & 0.009 & 1.9 & 4.4 \\
\hline
\end{tabular}

2010, and 2011 were 25,25 , and 55 percent, respectively, higher than the long-term average at the station $\left(197 \mathrm{ft}^{3} / \mathrm{s}\right)$, and annual mean flows in 2012 and 2013 were about 24 and 12 percent lower, respectively, than the long-term average. The interannual variation in streamflow reflects climatic conditions during the study period: annual total precipitation at the National Oceanic and Atmospheric Administration precipitation monitoring station in nearby Natick, Mass., was 50 inches (in.) in 2009, 52 in. in 2010, 57 in. in 2011, 44 in. in 2012, and 49 in. in 2013 (National Oceanic and Atmospheric Administration, 2015).

In 2009, above-normal flows (flows greater than the 75th percentile of mean daily flows) were mainly in the midsummer months, whereas above-normal flows in 2010 were mainly in the early spring. Below-normal flows (flows less than the 25th percentile) were measured in midsummer 2010. In 2011, flows during the first half of the year were generally normal, but flows during the late summer and fall were considerably above normal (on average, more than twice the 75th percentile). Flows during 2012 were within the normal range throughout much of the year; the low annual mean flow for 2012 reflects the low flows in the spring. Flows in 2013 were primarily below normal in late spring and late fall.

Streamflow is an integral component of loads computations because instream constituent loads are determined by both constituent concentrations and the volume of water in which the concentrations occur. Differences in instream loads can reflect differences in instream concentrations, differences in streamflow, or both. However, the effect of streamflow variations on instream loads depends on the constituent and 

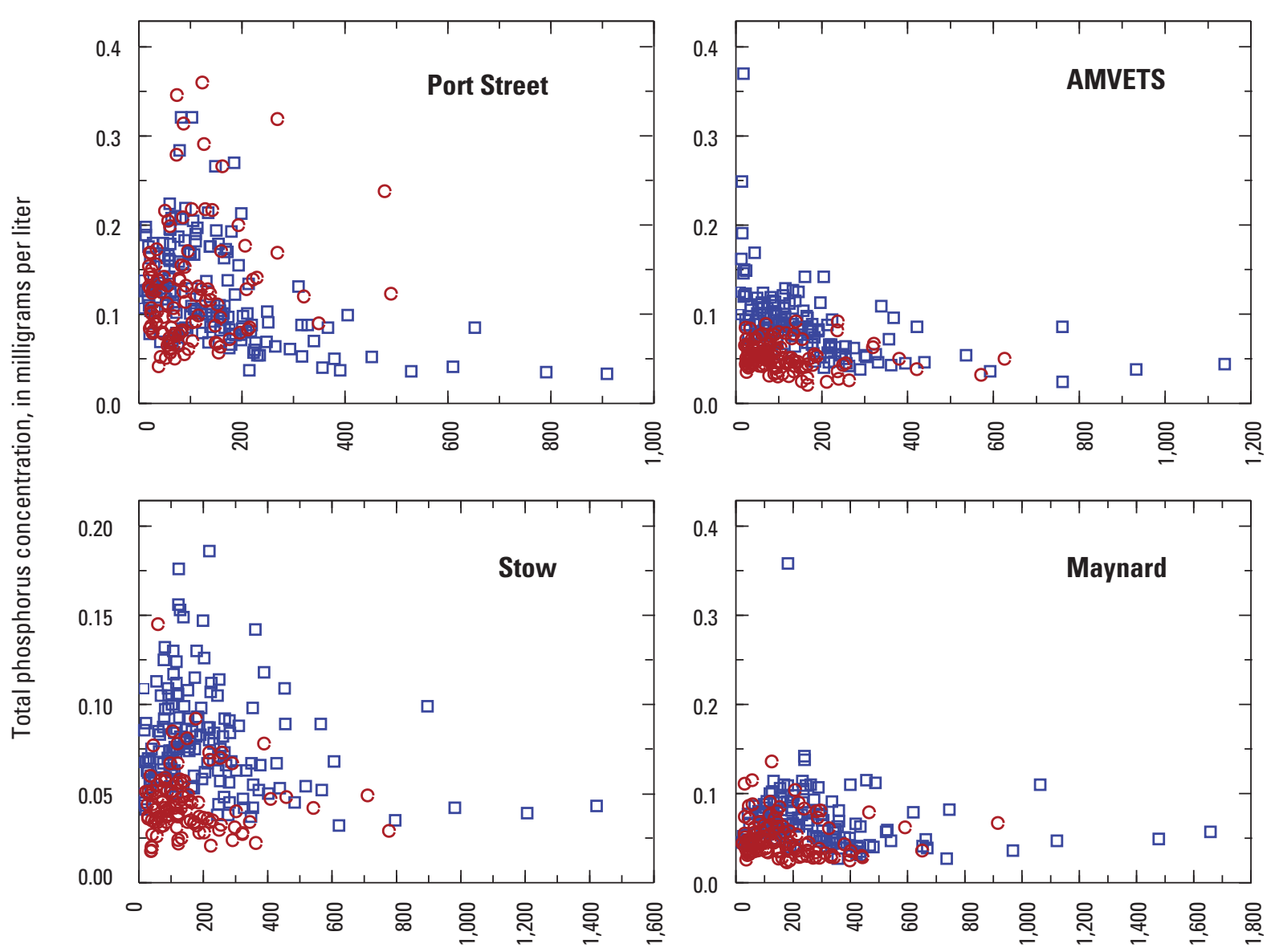

Mean daily streamflow during the sampling period, in cubic feet per second

\section{EXPLANATION}

ㅁefore WWTP upgrades, 2008-11

C After WWTP upgrades, 2012-13

Figure 11. Relations between streamflow and instream concentrations of total phosphorus at four water-qualitymonitoring stations on the Assabet River, Massachusetts, before and after wastewater-treatment-plant (WWTP) upgrades to reduce phosphorus in WWTP effluent. Sampling periods were 1 week long. See table 1 for full station names and numbers. 


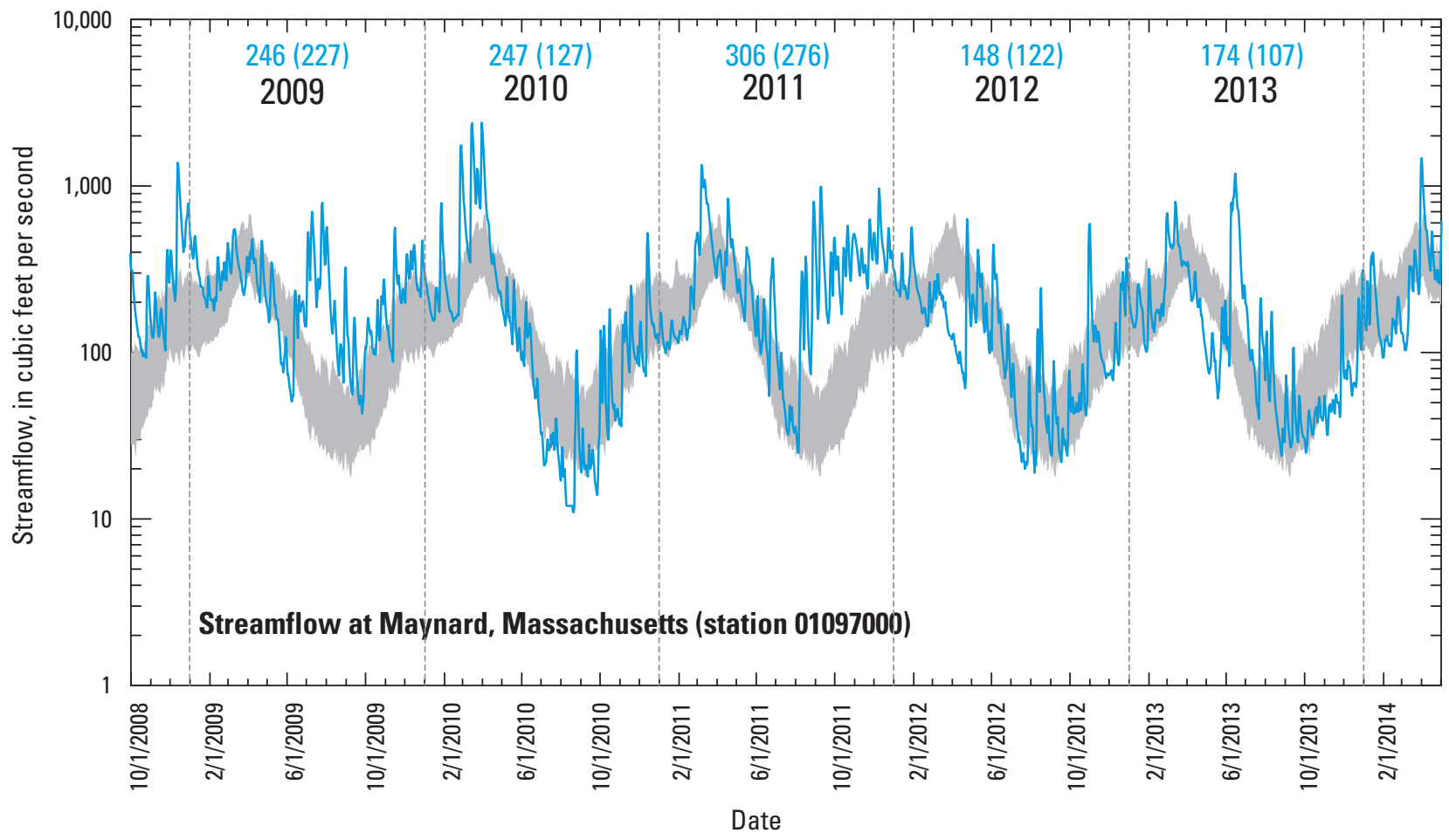

EXPLANATION

Mean daily streamflow, 1942-2014

Interquartile range-Top of the shaded area is

the 75th percentile and bottom of the

shaded area is the 25th percentile

Daily mean streamflow during

the study period, 10/1/2008 to 4/30/2014

246 (227) Annual mean (median) streamflow during the calendar year indicated

Figure 12. Interquartile range of mean daily streamflow from 1942 to 2014 at station 01097000 repeated for each calendar year and overlaid with daily mean streamflow during the study period, from October 1, 2008, to April 30, 2014, Assabet River, Maynard, Massachusetts. See table 1 for full station names. 
how it is delivered to the stream. For constituent loads from a WWTP, to the extent that the loads are independent of hydrologic conditions, variations in streamflow are less important than for constituent loads from sources distributed throughout a watershed that are delivered to the stream by overland runoff. If loads from WWTPs were completely independent of hydrologic conditions and were the only source of instream loads, then instream loads would not be affected by streamflow variation. This is because the same constituent mass delivered to a larger volume of stream water would result in lower instream concentrations but not a larger load than if it were delivered to a smaller volume of stream water.

The variation in streamflow during the sample-collection period is important to the present study because not all of the phosphorus loads in the river came from the WWTPs, and the WWTP loads are not completely independent of hydrologic conditions. A study conducted by ENSR International (2001) indicates that nearly all of the phosphorus loads in the river during dry weather come from the WWTPs; however, overland runoff can contribute substantially to the total phosphorus loads during wet weather. Flows and TP loads from the WWTPs were higher during periods of high streamflow, perhaps because of infiltration and inflow during wet weather.

Daily streamflow at the Port Street, AMVETS, and Stow monitoring stations was highly correlated with daily streamflow at the Maynard monitoring station. Linear regression analyses of daily streamflow at the Port Street, AMVETS, and Stow monitoring stations yielded R-squared $\left(R^{2}\right)$ values of $0.97,0.97$, and 0.99 , respectively. Mean annual flow increased by about 12 percent between the Port Street and AMVETS monitoring stations, by about 30 percent between the AMVETS and Stow monitoring stations, and by about 25 percent between the Stow and Maynard monitoring stations (table 1).

\section{Phosphorus Loads}

Total phosphorus loads for the three WWTPs were calculated from concentration and flow data reported by the WWTPs. Annual median TP loads decreased at the three WWTPs from 2009 to 2013 (fig. 13 and table 2), with the largest decrease following completion of all treatment-plant upgrades. The annual median TP load between 2009 and 2013 decreased by 91 percent (13.9 to 1.3 kilograms per day [kg/d]) at the Westborough WWTP, 87 percent ( 4.5 to $0.6 \mathrm{~kg} / \mathrm{d}$ ) at the Marlborough-Westerly WWTP, and 91 percent ( 7.0 to $0.6 \mathrm{~kg} / \mathrm{d}$ ) at the Hudson WWTP. Decreases in mean TP loads were slightly lower, at 75 percent for Westborough, 82 percent for Marlborough-Westerly, and 90 percent for Hudson (table 2). The years 2009 and 2013 are chosen for comparison here because (1) 2009 was the first full calendar year of the study and preceded the most changes in WWTP operations, and (2) 2013 was the last full calendar year of the study, postdated all changes in WWTP operations, and was a relatively normal flow year.
The changes in TP loads at the WWTPs were due primarily to changes in TP concentration rather than changes in wastewater flow. Flows from the WWTPs were lower in 2013 than in 2009, but by small percentages - total or annual mean flow was 14 percent lower at Westborough, 27 percent lower at Marlborough-Westerly, and 29 percent lower at Hudson in 2013 than in 2009. In contrast, median (mean) concentrations at the WWTPs were 89 (73) percent lower at Westborough, 83 (77) percent lower at Marlborough-Westerly, and 86 (86) percent lower at Hudson in 2013 than in 2009 (table 2).

Instream TP and orthoP loads were calculated from concentrations and flows measured at four USGS monitoring stations. Annual median TP loads between 2009 and 2013 (fig. 14 and table 3) decreased from $33 \mathrm{~kg} / \mathrm{d}$ in 2009 to $14 \mathrm{~kg} / \mathrm{d}$ in 2013 at the Port Street monitoring station (57 percent), from $27 \mathrm{~kg} / \mathrm{d}$ in 2009 to $7 \mathrm{~kg} / \mathrm{d}$ in 2013 at the AMVETS monitoring station (74 percent), from $38 \mathrm{~kg} / \mathrm{d}$ in 2009 to $9 \mathrm{~kg} / \mathrm{d}$ in 2013 at the Stow monitoring station (76 percent), and from $38 \mathrm{~kg} / \mathrm{d}$ in 2009 to $11 \mathrm{~kg} / \mathrm{d}$ in 2013 at the Maynard monitoring station (71 percent). Changes in annual mean TP loads were smaller: from 37 to $28 \mathrm{~kg} / \mathrm{d}$ at the Port Street monitoring station (24 percent), from 32 to $13 \mathrm{~kg} / \mathrm{d}$ at the AMVETS monitoring station (59 percent), from 44 to $14 \mathrm{~kg} / \mathrm{d}$ at the Stow monitoring station (68 percent), and from 46 to $20 \mathrm{~kg} / \mathrm{d}$ at the Maynard monitoring station (56 percent). Instream loads of orthoP also decreased between 2009 and 2013. Annual median orthoP loads between 2009 and 2013 decreased from $4.2 \mathrm{~kg} / \mathrm{d}$ in 2009 to $1.4 \mathrm{~kg} / \mathrm{d}$ at the Port Street monitoring station (67 percent), from $6.0 \mathrm{~kg} / \mathrm{d}$ in 2009 to $1.1 \mathrm{~kg} / \mathrm{d}$ in 2013 at the AMVETS monitoring station ( 82 percent), from $8.7 \mathrm{~kg} / \mathrm{d}$ in 2009 to $1.1 \mathrm{~kg} / \mathrm{d}$ in 2013 at the Stow monitoring station (87 percent), and from $9.1 \mathrm{~kg} / \mathrm{d}$ in 2009 to $1.9 \mathrm{~kg} / \mathrm{d}$ in 2013 at the Maynard monitoring station (79 percent).

The changes in total instream TP loads, although smaller in terms of percentages than the decreases in WWTP TP loads, are comparable in magnitude. The decrease in annual mean TP loads between 2009 and 2013 at the AMVETS monitoring station $(19.4 \mathrm{~kg} / \mathrm{d})$ is comparable with the combined decreases in annual mean TP loads from the upstream WWTPs at Westborough and Marlborough-Westerly $(16.8 \mathrm{~kg} / \mathrm{d})$. The decreases in annual mean TP loads between 2009 and 2013 at the Stow monitoring station $(30 \mathrm{~kg} / \mathrm{d})$ and at the Maynard monitoring station $(26 \mathrm{~kg} / \mathrm{d})$ are comparable with combined decreases in annual mean TP loads from the three upstream WWTPs at Westborough, Marlborough-Westerly, and Hudson $(24 \mathrm{~kg} / \mathrm{d})$. Thus, the reductions in mean TP instream loads between 2009 and 2013 differed by only 14, 22, and 8 percent at the AMVETS, Stow, and Maynard monitoring stations, respectively. The observed decreases in instream loads are slightly larger than observed decreases in WWTP loads (tables 2 and 3). This is consistent with smaller loads of phosphorus from sources other than WWTPs being delivered to the river through overland runoff and groundwater discharge during the later years of the study, when streamflows were lower than in the earlier years. Sources of phosphorus to the river other than WWTPs, such as overland runoff or 


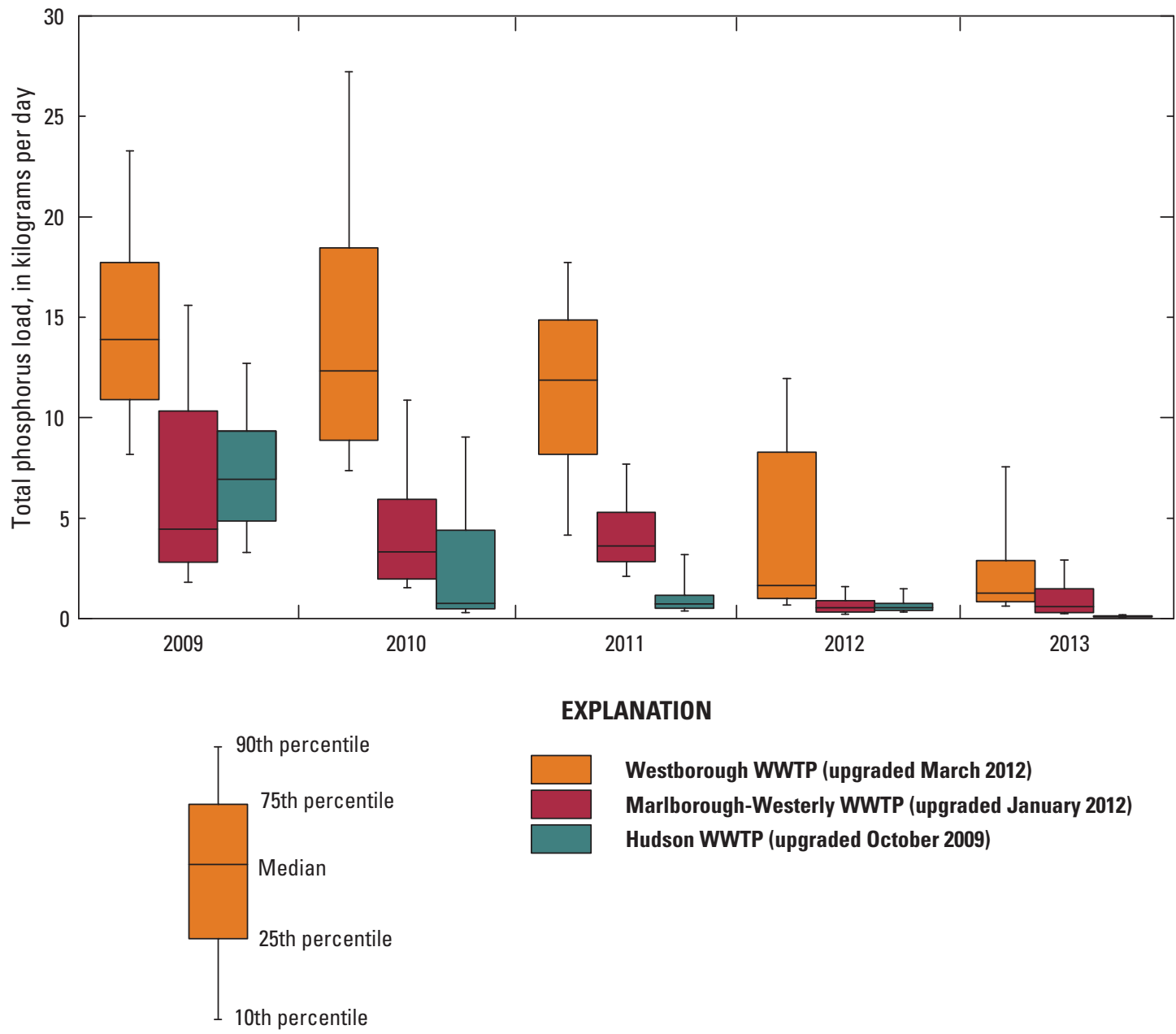

Figure 13. Annual distributions of estimated daily total phosphorus loads in wastewater-treatment-plant (WWTP) effluent into the Assabet River, Massachusetts, 2009-2013.

internal loading from sediments, were not directly measured as part of the present study; the observed changes in instream phosphorus loads represent net changes that may have been affected by such sources in addition to reductions in WWTP discharges.

\section{Seasonal Differences in Phosphorus Concentrations and Loads}

Following completion of all WWTP upgrades in March 2012, TP concentrations in treated effluent ranged from 0.05 to $0.08 \mathrm{mg} / \mathrm{L}$ during the growing season (April through October) and 0.11 to $0.34 \mathrm{mg} / \mathrm{L}$ during the nongrowing season (November through March) (Savoie, 2016). These releases were consistent with the TMDL-mandated limit of $0.1 \mathrm{mg} / \mathrm{L}$ for the growing season and were well below the limit of $1.0 \mathrm{mg} / \mathrm{L}$ for the nongrowing season.
In each year of the study, total phosphorus concentrations and loads released in treated effluent typically were greater at all three WWTPs during the nongrowing season than during the growing season, both before and after the TMDLmandated upgrades (figs. 15 and 16). Median before-upgrade loads reported by the Westborough WWTP ranged from 10 to $16 \mathrm{~kg} / \mathrm{d}$, with median nongrowing-season loads slightly larger than growing-season loads. Median after-upgrade loads in effluent from the Westborough WWTP were much smaller during all seasons (3.0 to $6.0 \mathrm{~kg} / \mathrm{d}$ during the nongrowing season and $1 \mathrm{~kg} / \mathrm{d}$ during the growing season) than median before-upgrade loads, but the difference between seasons was greater after the upgrade. At the Marlborough-Westerly WWTP in 2009, all nongrowing-season loads were marginally larger than growing-season loads both before and after the upgrades, aside from one large TP load $(16 \mathrm{~kg} / \mathrm{d})$ in the 2009 nongrowing season. The Hudson WWTP completed 

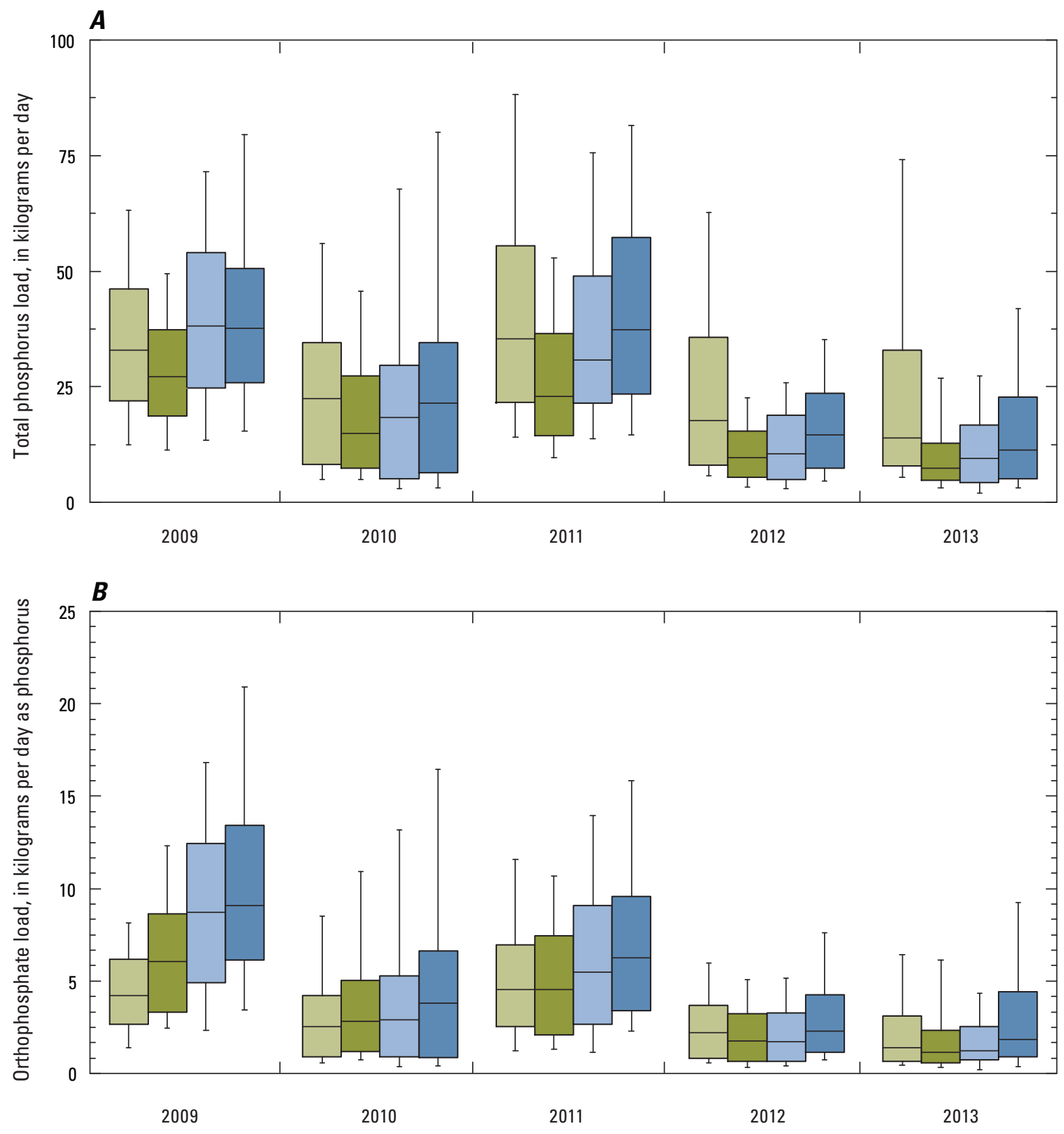

\section{EXPLANATION}
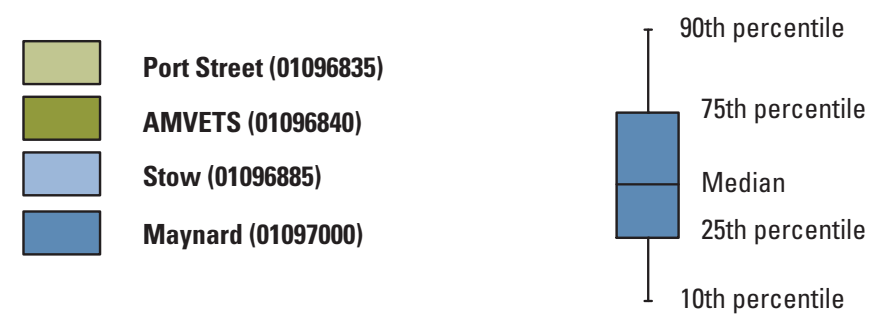

Figure 14. Annual distributions of estimated $A$, total phosphorus and $B$, orthophosphate loads in weekly flowproportional composite samples from four water-quality-monitoring stations on the Assabet River, Massachusetts, 2009-2013. See table 1 for full station names. 


\section{A. Westborough WWTP (upgraded March 2012)}

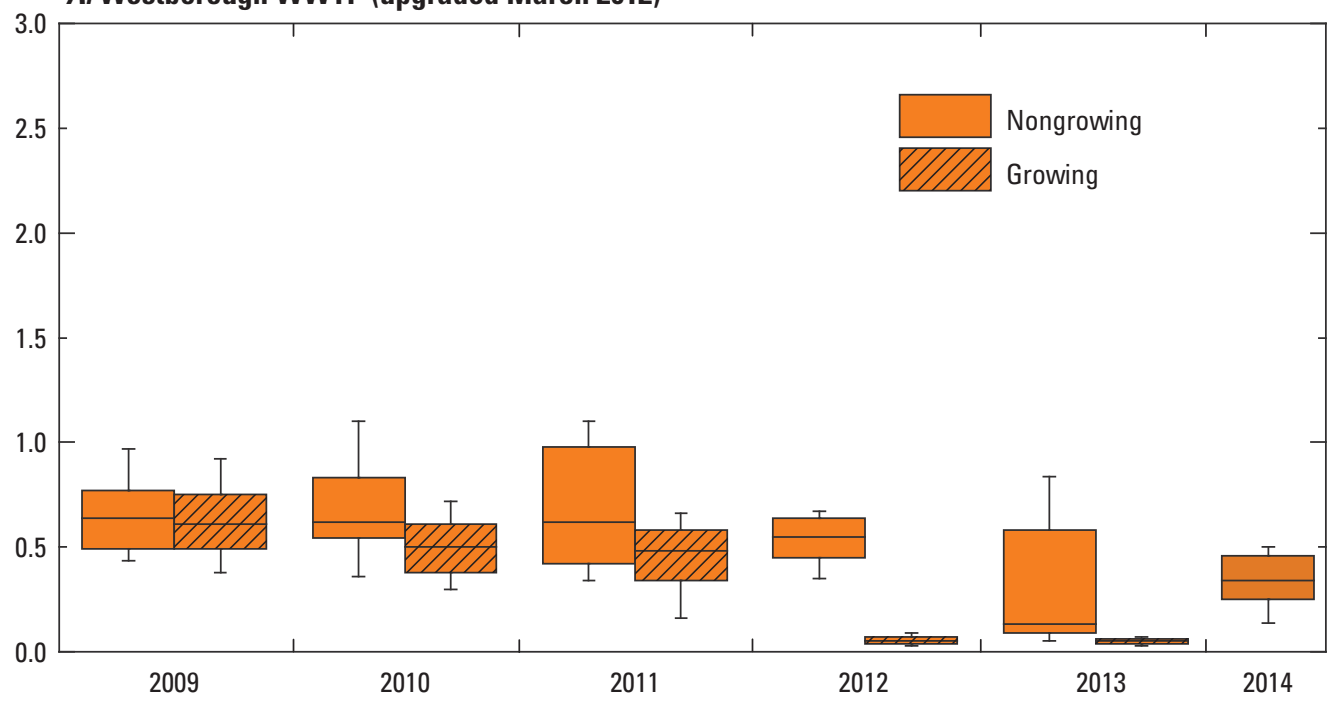

B. Marlborough-Westerly WWTP (upgraded January 2012)

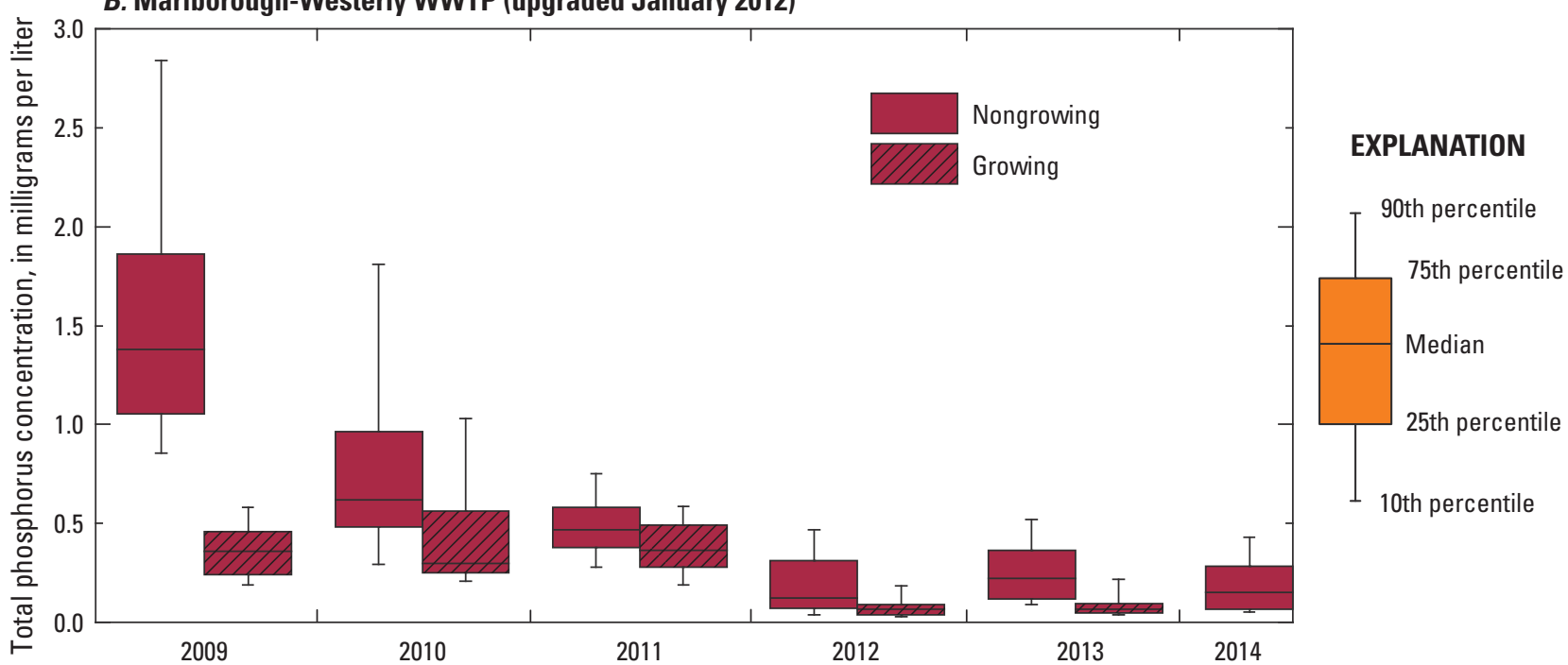

C. Hudson WWTP (upgraded October 2009)

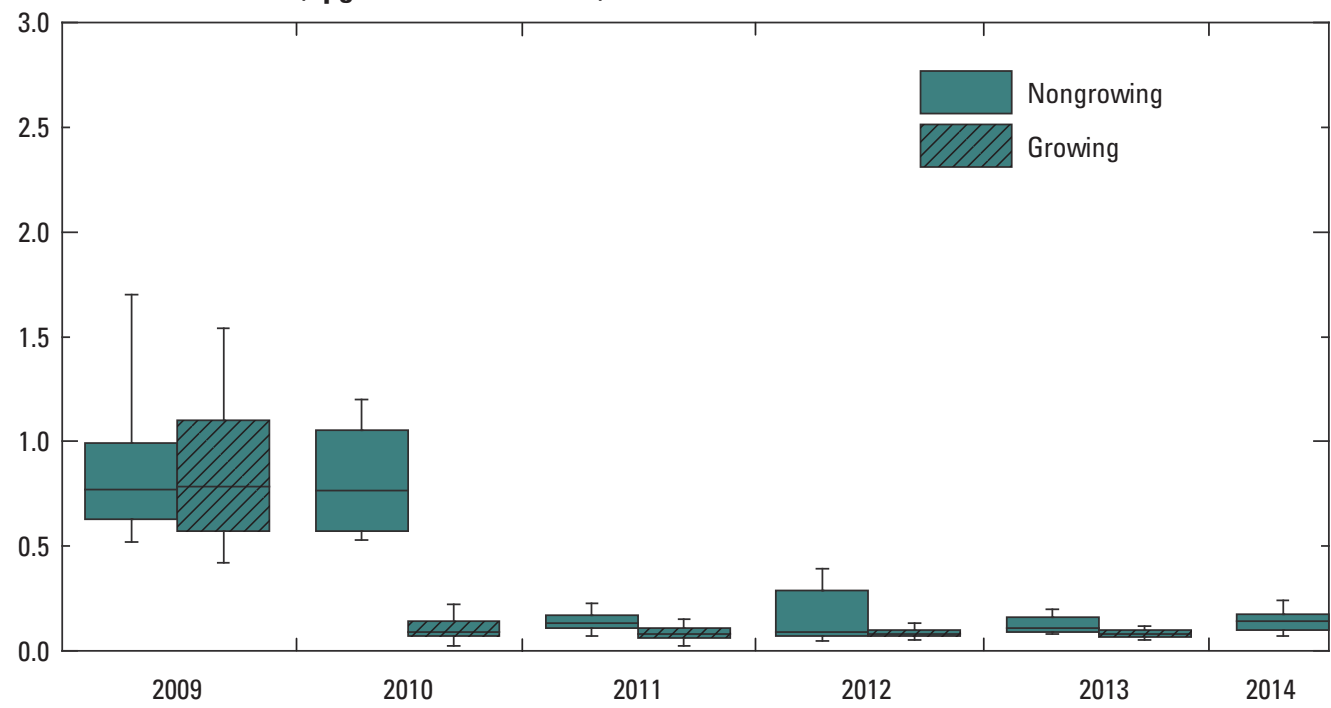

Figure 15. Seasonal distributions of estimated daily total phosphorus concentrations in effluent from the wastewatertreatments plants (WWTPs) in $A$, Westborough, $B$, Marlborough-Westerly, and $C$, Hudson, Massachusetts, during nongrowing (November through March) and growing (April through October) seasons, on the Assabet River, Massachusetts, 2009-2014. 
A. Westborough WWTP (upgraded March 2012)

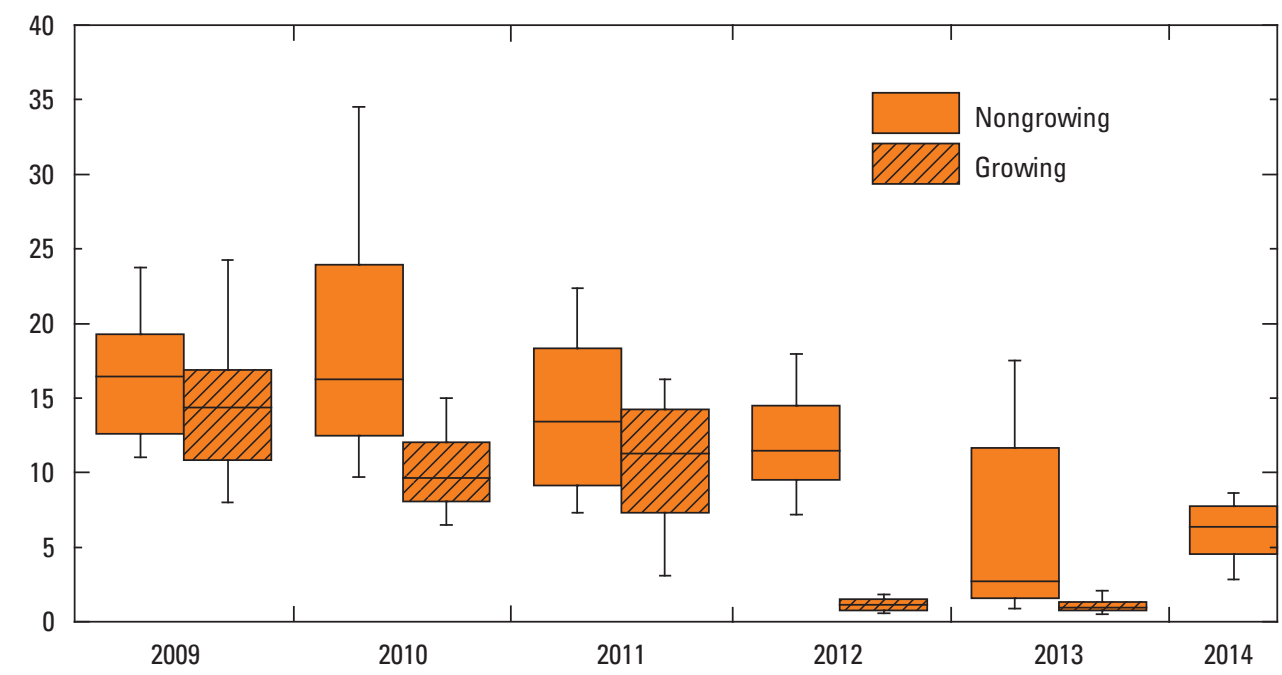

B. Marlborough-Westerly WWTP (upgraded January 2012)

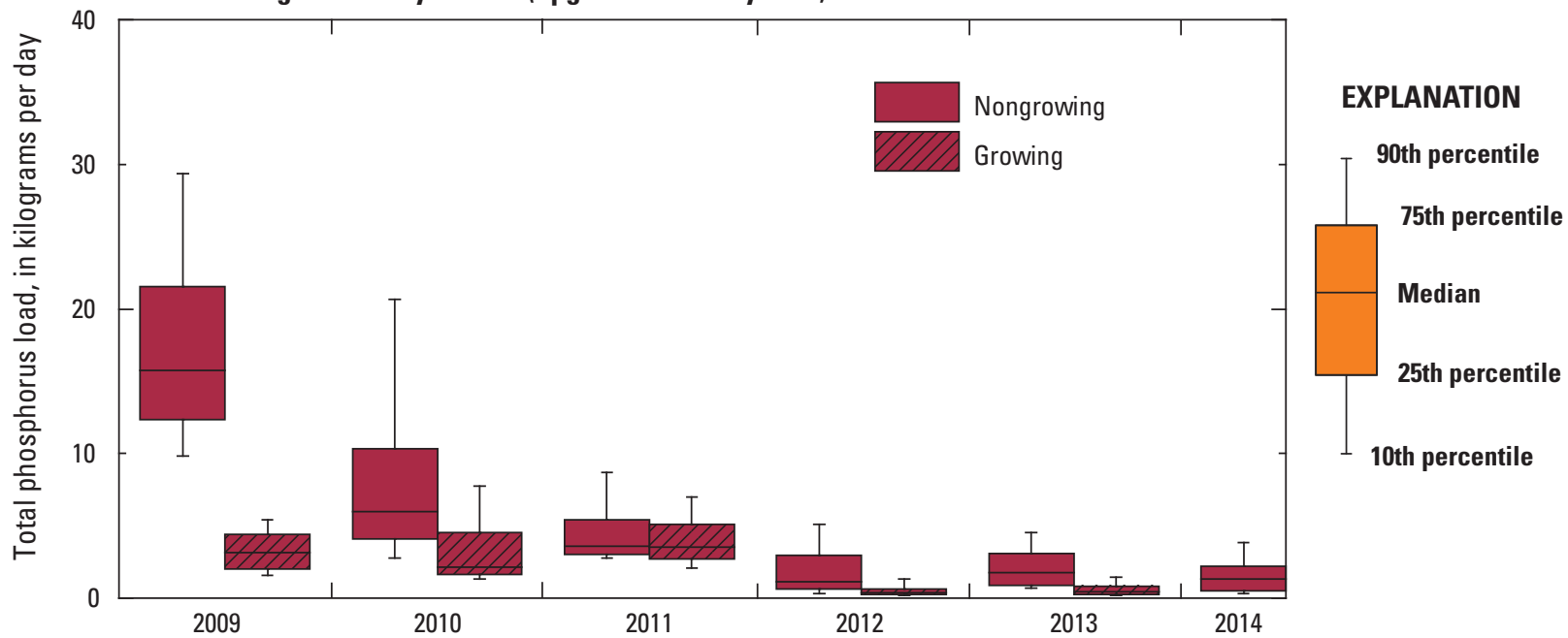

C. Hudson WWTP (upgraded October 2009)

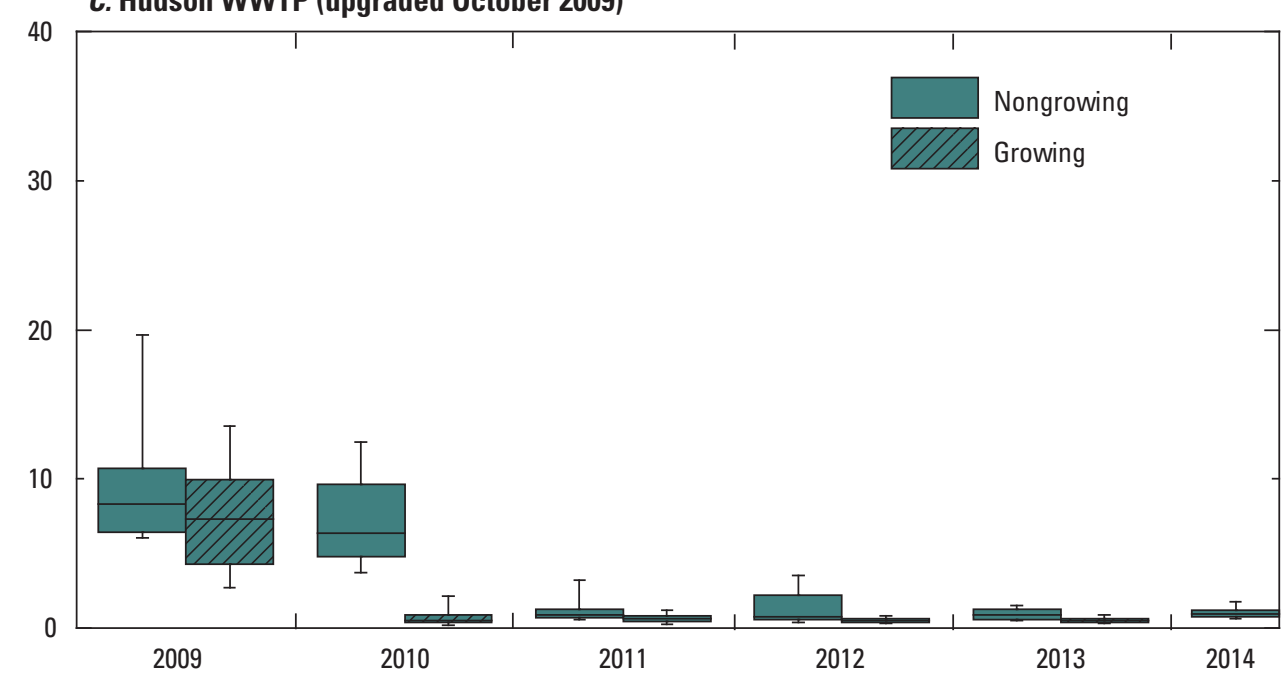

Figure 16. Seasonal distributions of estimated daily total phosphorus loads in effluent from the wastewater-treatment plants (WWTPs) in $A$, Westborough, $B$, Marlborough-Westerly, and $C$, Hudson, Massachusetts, during nongrowing (November through March) and growing (April through October) seasons, 2009-2014. 
its upgrades in October 2009; therefore, two seasons (one nongrowing and one growing) of before-upgrade data were available. Annual median TP loads at the Hudson WWTP were 7.0 to $8.0 \mathrm{~kg} / \mathrm{d}$, with little seasonal variation before the upgrade. After-upgrade loads decreased to $6.0 \mathrm{~kg} / \mathrm{d}$ in the nongrowing 2010 season and decreased further to 0.5 to $1.0 \mathrm{~kg} / \mathrm{d}$ in growing and nongrowing seasons for the remainder of the study period (2010 to 2013) (fig. 16).

Seasonal variations in TP and orthoP concentrations also were observed instream at the Assabet River monitoring stations; however, unlike WWTP concentrations, most instream growing-season concentrations were greater than instream nongrowing-season concentrations (figs. 17 and 18). The growing-season months include the summer and early fall months of low streamflow, so higher concentrations during the growing season likely result partly from less dilution of WWTP loads during these months.

Instream growing-season loads at the Assabet River monitoring stations were typically similar or slightly higher than nongrowing-season loads (figs. 19 and 20). Less seasonal variation in phosphorus loading was observed during the study period at the four instream monitoring stations than in the WWTP effluent. Differences in nongrowing and growing median TP and orthoP loads were greater before the WWTP upgrades than after the upgrades. Seasonal TP concentrations at the Port Street monitoring station were about the same before and after the WWTP upgrades (fig. 17), and loads decreased after the upgrades and after-upgrade loads were 11 to $16 \mathrm{~kg} / \mathrm{d}$ with little seasonal variation. At the AMVETS monitoring station, after-upgrade median TP loads were $9 \mathrm{~kg} / \mathrm{d}$ during the nongrowing season and $7 \mathrm{~kg} / \mathrm{d}$ during the growing season. The after-upgrade median TP load at the Stow monitoring station ranged from 9 to $12 \mathrm{~kg} / \mathrm{d}$ during the nongrowing season and 8 to $9 \mathrm{~kg} / \mathrm{d}$ during the growing season. At the Maynard monitoring station, the after-upgrade median TP loads were $13 \mathrm{~kg} / \mathrm{d}$ during the nongrowing season and $11 \mathrm{~kg} / \mathrm{d}$ during the growing season (fig. 19). Similar decreases in orthoP loads during the growing seasons were observed (fig. 20). In general, growing seasons tend to have months with lower streamflow and nongrowing seasons tend to have months with higher streamflow. After the upgrades, even though concentrations tended to be higher in the growing seasons, the loads were about the same between growing and nongrowing seasons.

\section{Effects of Impoundments on Instream Phosphorus Loads}

The effects of run-of-the-river impoundments on phosphorus dynamics in the Assabet River system were examined by monitoring changes in phosphorus loads entering and leaving the two impoundments in the study area. The two impoundments, each of which is bracketed by water-qualitymonitoring stations, have different physical characteristics. The Hudson impoundment is smaller and has a larger ponded area than Ben Smith impoundment. The Assabet River meanders and has a more streamlike character upstream from the Ben Smith impoundment dam than upstream from the Hudson impoundment dam. Both impoundments have tributaries entering between the monitoring stations. Also, both downstream monitoring stations (AMVETS and Maynard) may be affected by storm runoff from the towns of Hudson and Maynard, respectively. These potential sources of phosphorus were not measured in this study and complicate the use of only the upstream and downstream monitoring stations in understanding the effects of the reservoirs on the phosphorus dynamics. For each impoundment, loads were compared in terms of estimated total annual loads released by the WWTPs and as measured at the monitoring stations upstream and downstream. Differences between upstream and downstream loads were also compared.

\section{Hudson Impoundment}

Estimated total annual TP loads recorded at the Port Street monitoring station at the upstream end of the impoundment were greater than total annual TP loads at the downstream monitoring station at the AMVETS monitoring station in each year of the study (fig. 21A). Annual loads at both the upstream and downstream stations generally decreased throughout the study. Annual TP loads estimated at the Port Street monitoring station were 13 percent greater than loads at the AMVETS monitoring station in 2009 and 2010, 34 percent greater in 2011, and 55 percent greater in 2012 and 2013. Estimated total weekly loads entering the Hudson impoundment near the Port Street monitoring station frequently exceeded loads leaving the impoundment during the sampling period from 2008 to 2014. Subtracting the downstream loads from the upstream loads demonstrates that upstream loads exceeded downstream loads (fig. 22A). On several occasions before the WWTP upgrades, downstream loads exceeded upstream loads during short-lived streamflow peaks. After the upgrades, loads were rarely greater leaving the impoundment than entering it.

Before the WWTP upgrades, orthoP loads at the AMVETS monitoring station (the impoundment outlet) were greater than loads at the upstream end of the impoundment at the Port Street monitoring station, and after the WWTP upgrades, orthoP loads were slightly greater at the Port Street monitoring station than at the AMVETS monitoring station (figs. $21 B$ and 22B). The consistent difference in TP loads upstream and downstream from Hudson impoundment, such that there always appeared to be more TP entering the impoundment than leaving, could suggest that the impoundment is a sink for TP. However, TP concentrations and loads at the Port Street monitoring station, especially towards the end of the study, may have been affected by resuspension or other instream processes, as discussed in the "Phosphorus Concentrations" section, and this could be why TP loads did not decrease at the Port Street monitoring station after WWTP upgrades. Also, unlike the annual loads at the AMVETS monitoring station, which decreased by 


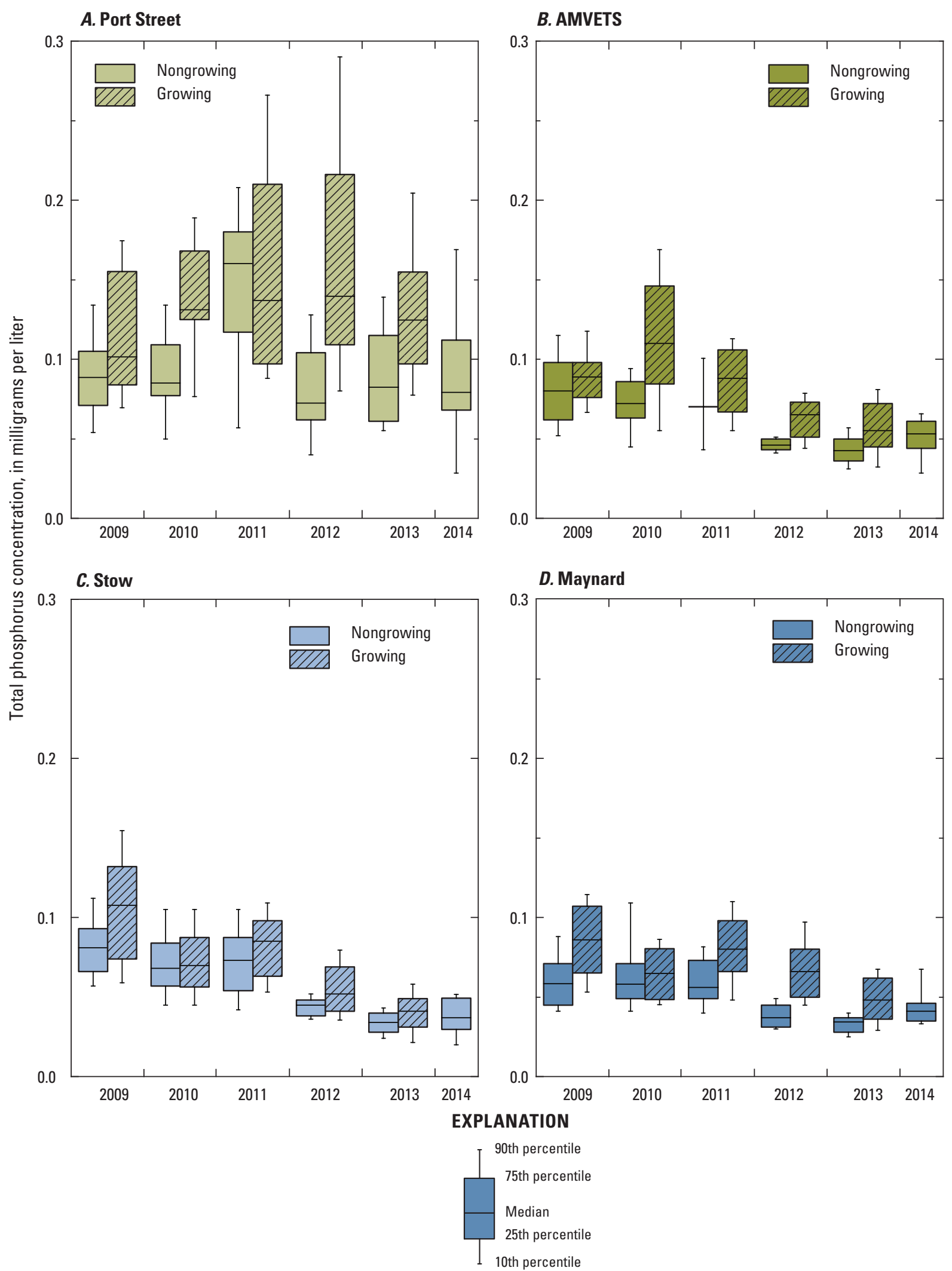

Figure 17. Seasonal distributions of estimated daily total phosphorus concentrations in flow-proportional composite samples from water-quality-monitoring stations $A$, Port Street, $B$, AMVETS, $C$, Stow, and $D$, Maynard during nongrowing (November through March) and growing (April through October) seasons, on the Assabet River, Massachusetts, from 2009 to 2014. See table 1 for full station names and numbers. 


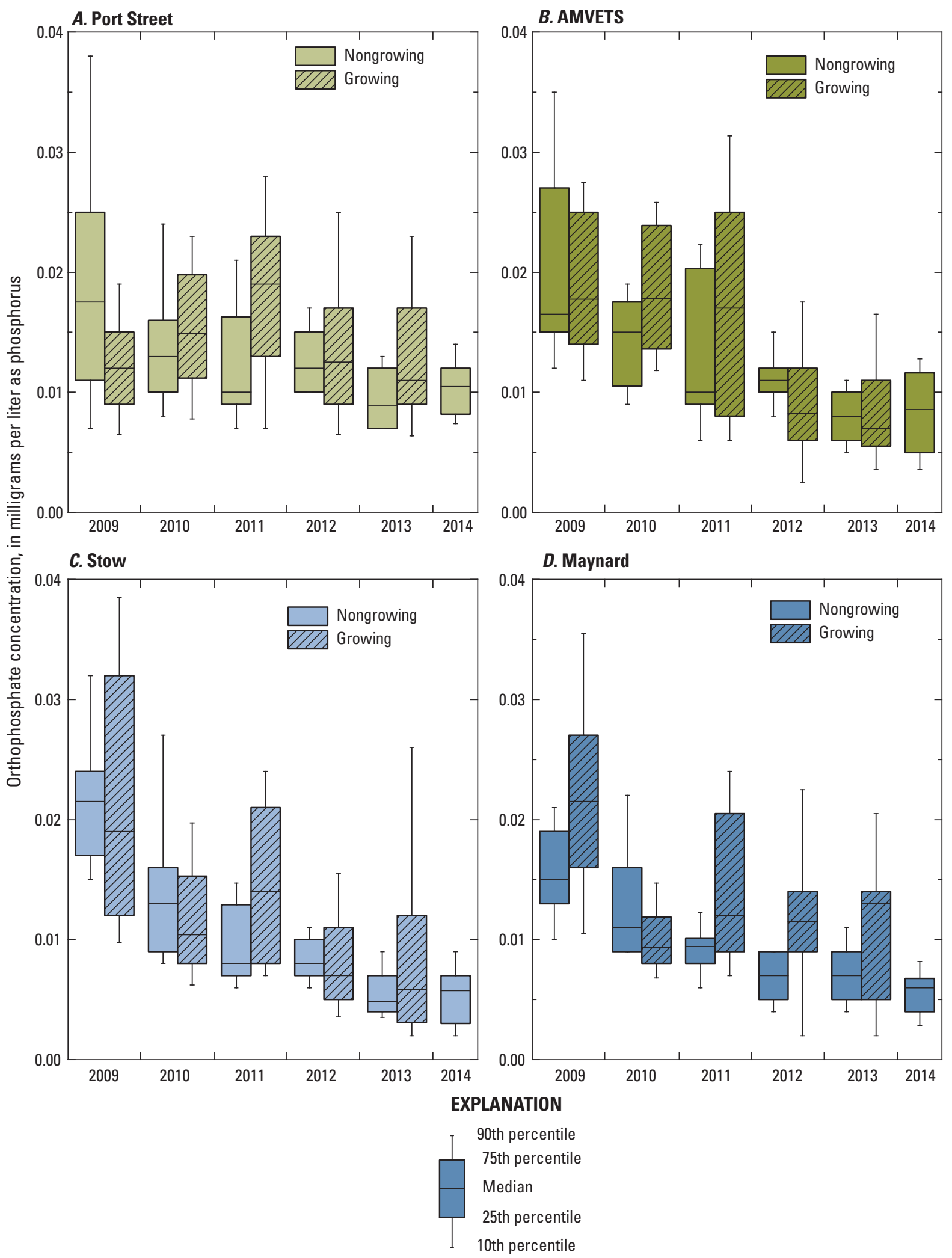

Figure 18. Seasonal distributions of estimated daily orthophosphate concentrations in flow-proportional composite samples from water-quality-monitoring stations $A$, Port Street, $B$, AMVETS, $C$, Stow, and $D$, Maynard during nongrowing (November through March) and growing (April through October) seasons, on the Assabet River, Massachusetts, from 2009 to 2014. See table 1 for full station names and numbers. 

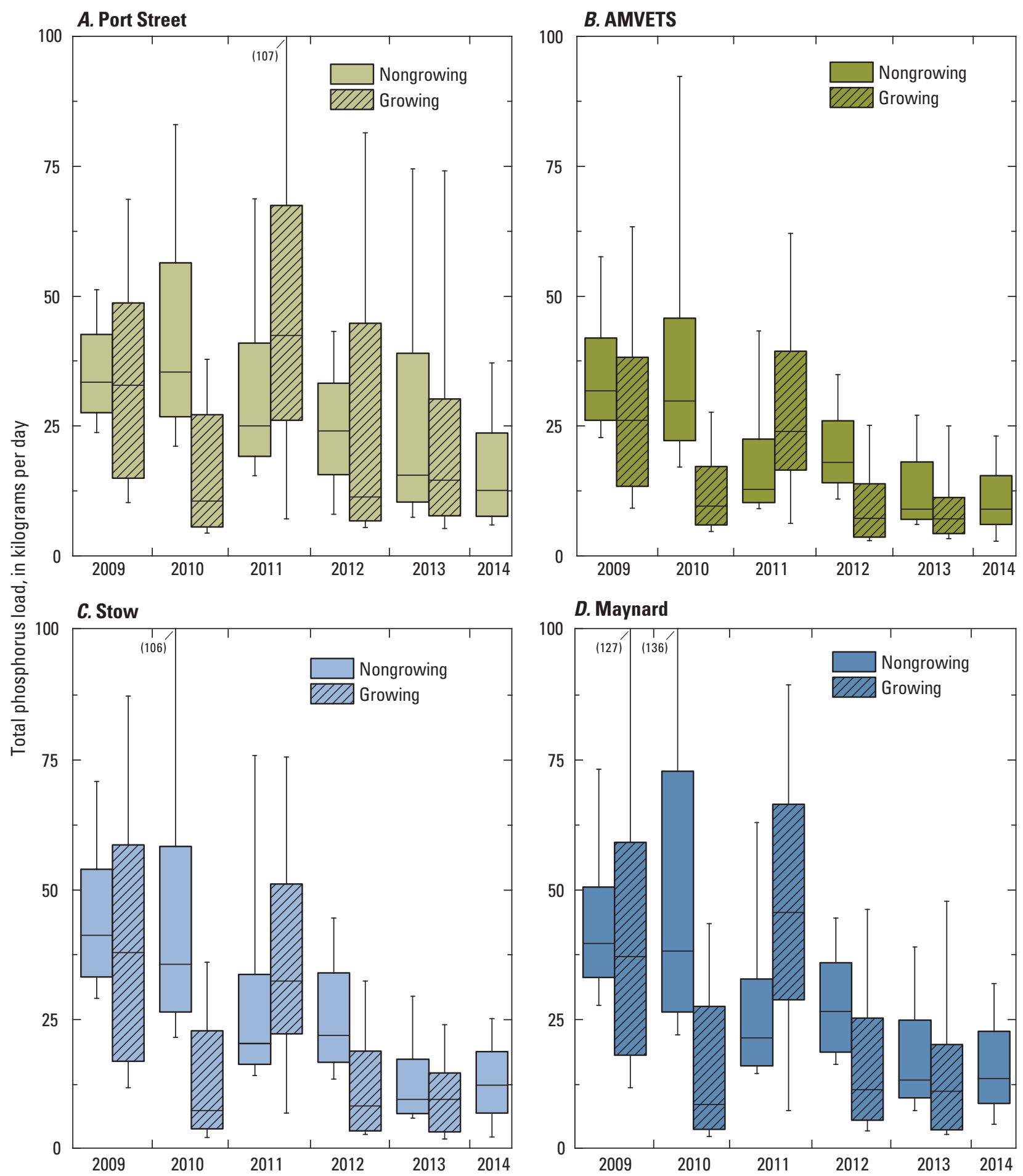

\section{EXPLANATION}

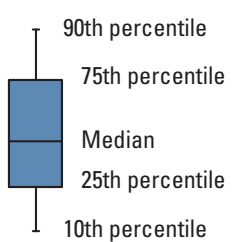

Figure 19. Seasonal distributions of estimated daily total phosphorus loads in flow-proportional composite samples from water-quality-monitoring stations $A$, Port Street, $B$, AMVETS, $C$, Stow, and $D$, Maynard during nongrowing (November through March) and growing (April through October) seasons, on the Assabet River, Massachusetts, from 2009 to 2014 . See table 1 for full station names and numbers. 


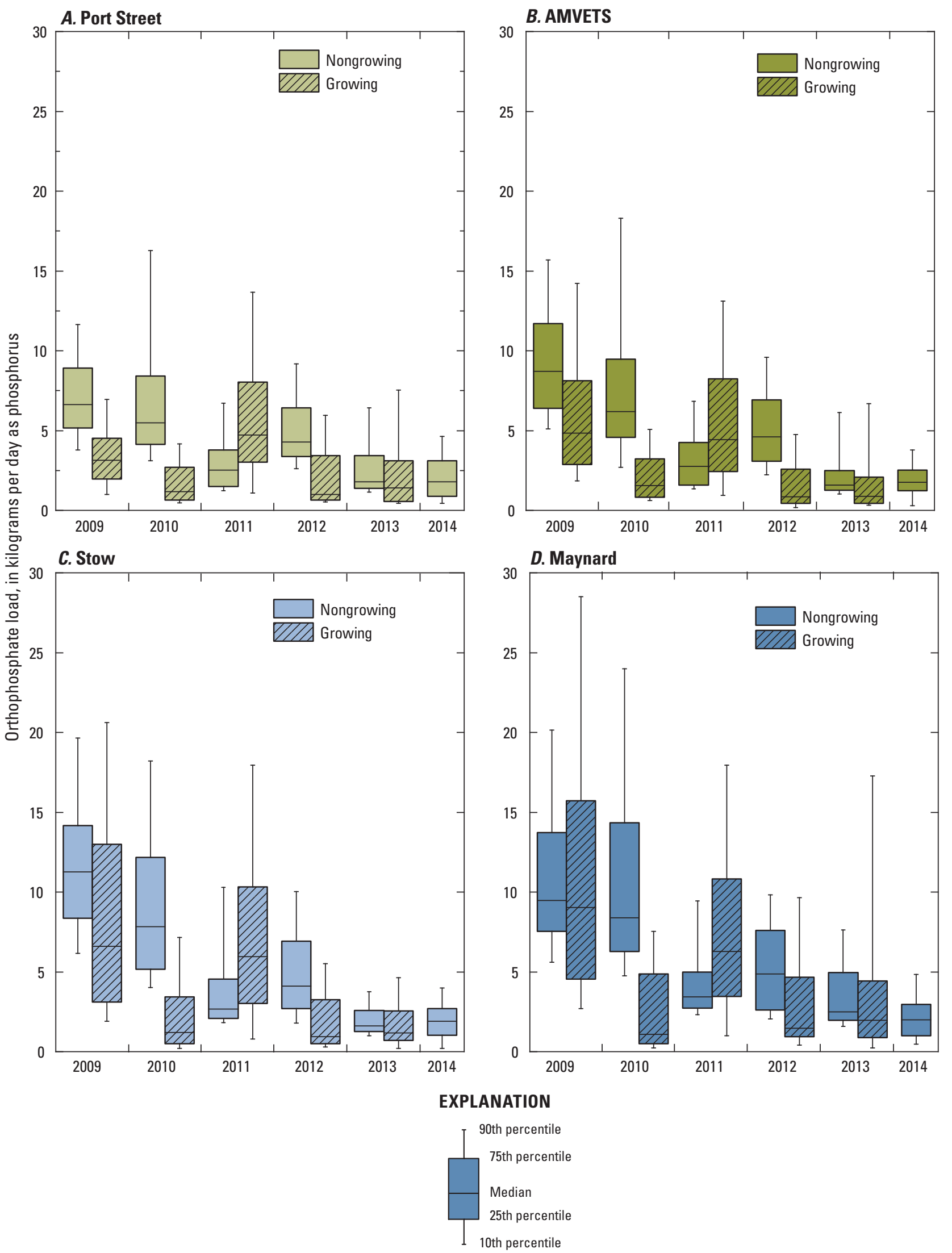

Figure 20. Seasonal distributions of estimated daily orthophosphate loads in flow-proportional composite samples from water-quality-monitoring stations $A$, Port Street, $B$, AMVETS, $C$, Stow, and $D$, Maynard during nongrowing (November through March) and growing (April through October) seasons, on the Assabet River, Massachusetts, from 2009 to 2014. See table 1 for full station names and numbers. 

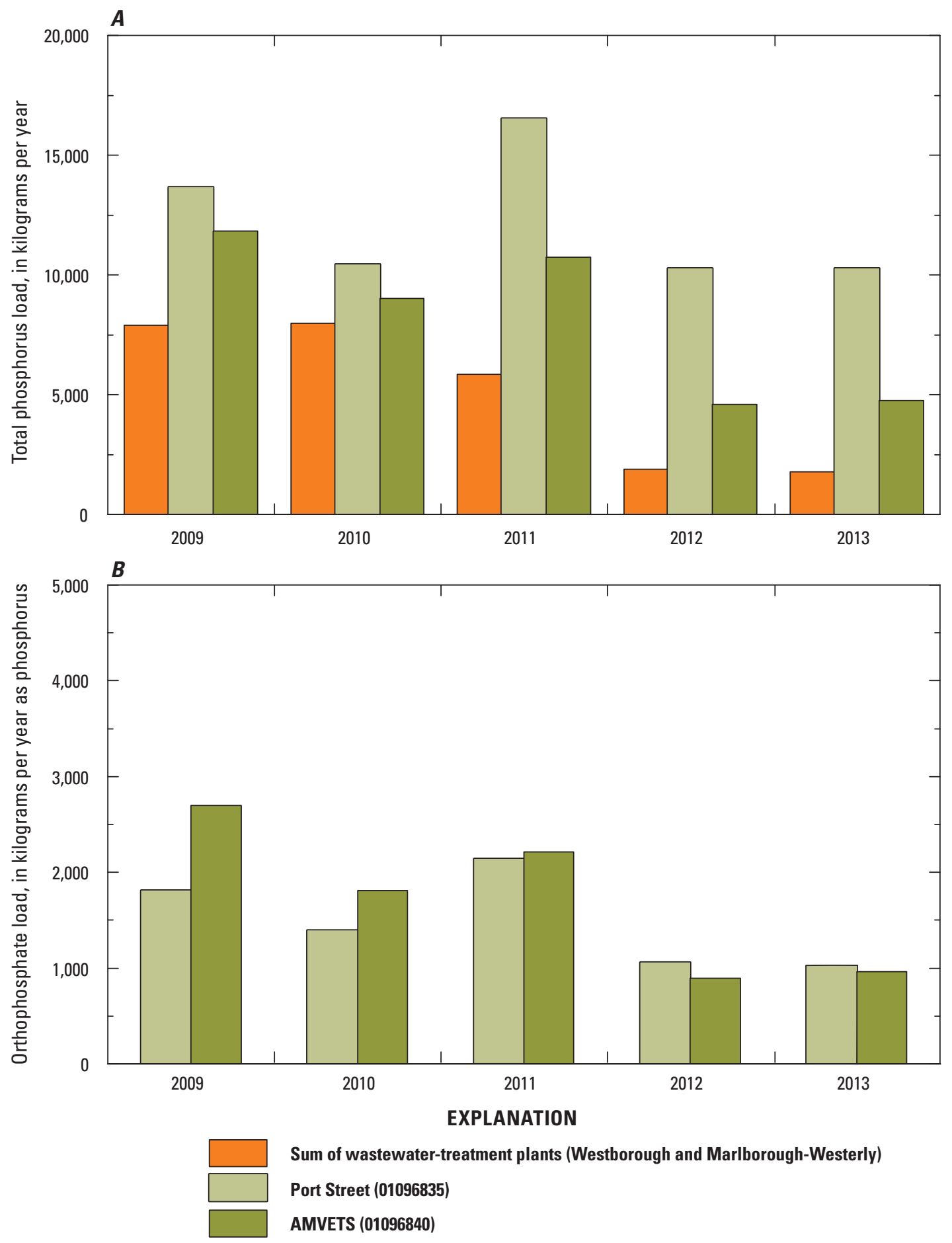

Figure 21. Estimated annual loads of $A$, total phosphorus of discharges from wastewater-treatment plants (WWTPs) at Westborough and Marlborough-Westerly and instream at the Port Street and AMVETS waterquality-monitoring stations and $B$, orthophosphate instream at the Port Street and AMVETS water-qualitymonitoring stations on the Assabet River, Massachusetts, 2009-2013. See table 1 for full station names. 

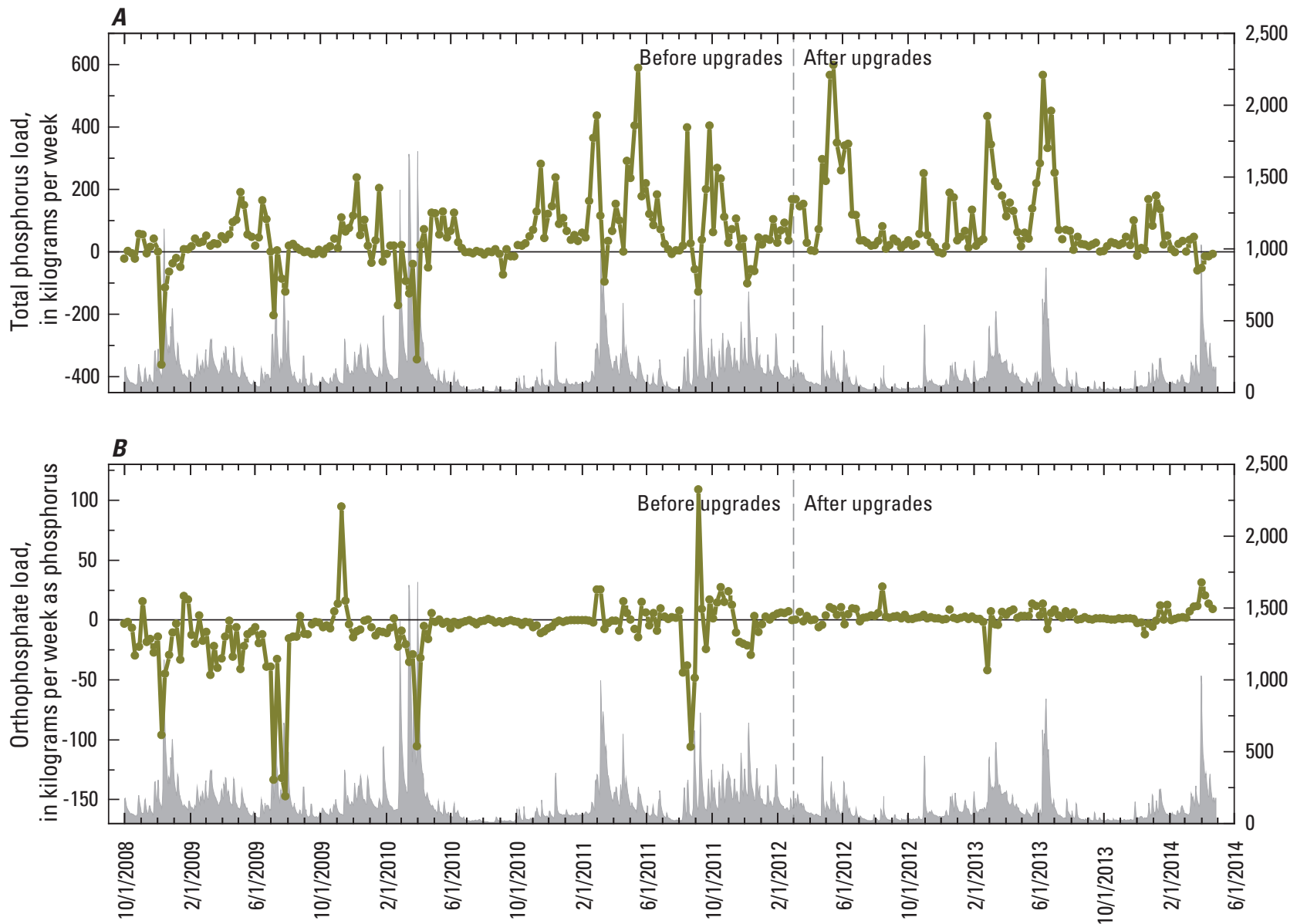

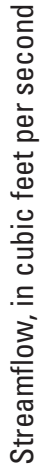

EXPLANATION

Streamflow

Upstream load minus downstream load

Figure 22. Streamflow and differences between estimated weekly loads of $A$, total phosphorus and $B$, orthophosphate upstream and downstream from the Hudson impoundment on the Assabet River, Massachusetts, October 2008 through April 2014.

a magnitude comparable to that of the decrease in WWTP loads (with the exception of 2011, when there was greater precipitation), the decrease in annual loads during the study at the Port Street monitoring station was not as great as the decrease in upstream WWTP loads over the study period. Additional investigation would be needed to determine the extent to which these processes affected the calculated TP loads at the Port Street monitoring station.

Results of the application of the Wilcoxon matched-pair signed-rank tests further support the interpretation that loads upstream and downstream from the Hudson impoundment were significantly different ( $p$ less than 0.001) for TP and orthoP before and after the WWTP upgrades. Upstream TP loads were most often larger than downstream loads before and after the WWTP upgrades, and downstream orthoP loads were often larger before the upgrades; after the upgrades, the pattern was reversed so that orthoP loads were slightly larger upstream than downstream.

\section{Ben Smith Impoundment}

Estimated total annual TP loads were consistently greater (up to 40 percent) at the downstream end of the Ben Smith impoundment, as observed at the Maynard monitoring station, than they were upstream at the Stow monitoring station (fig. 23A). The pattern of decreasing annual loads estimated entering and exiting the Ben Smith impoundment mimics the pattern reported by the WWTPs (with the exception of 2011, when precipitation was greater than in other years), with a 32 percent decrease at the Stow monitoring station 

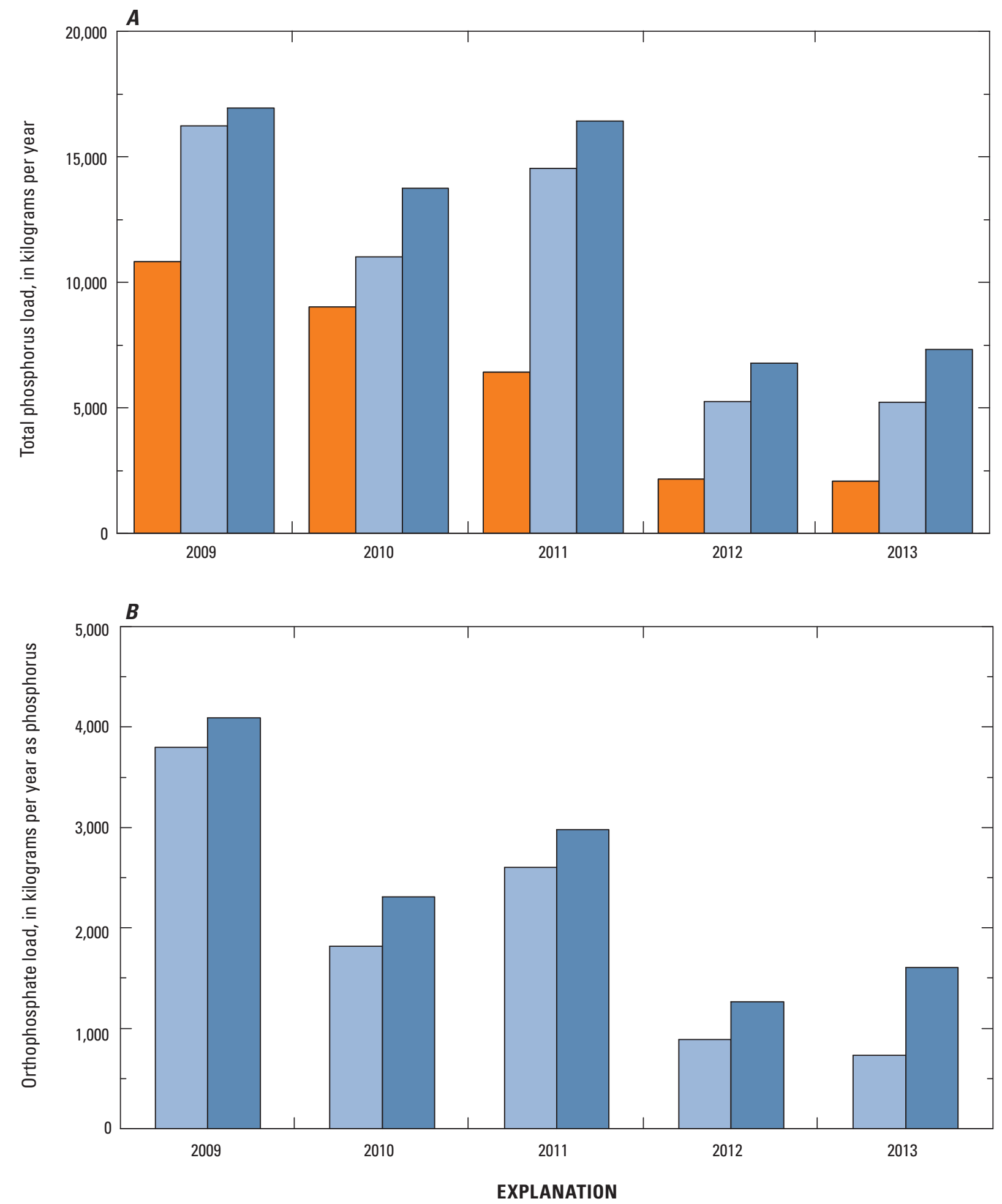

Sum of wastewater-treatment plants (Westborough, Marlborough-Westerly, and Hudson)

Stow (01096885)

Maynard (01097000)

Figure 23. Estimated annual loads of $A$, total phosphorus discharges from the wastewater-treatment plants (WWTPs) at Westborough, Marlborough-Westerly, and Hudson and instream at the Stow and Maynard water-quality-monitoring stations and $B$, orthophosphate instream at the Stow and Maynard water-quality-monitoring stations on the Assabet River, Massachusetts, from 2009 to 2013. See table 1 for full station names. 
and 19 percent decrease at the Maynard monitoring station between 2009 and 2010; loads increased by the same magnitude from 2010 to 2011 and then decreased by about 60 percent in 2012 and 2013. Estimated total weekly loads exiting the Ben Smith impoundment near the Maynard monitoring station frequently (with the exception of 2009) exceeded loads entering the impoundment during the sampling period from 2008 to 2014 (fig. 24A).

Estimated annual orthoP loads also were consistently greater at the downstream end of Ben Smith impoundment than they were at the upstream end (figs. $23 B$ and $24 B$ ). The differences in magnitudes of both phosphorus species were, however, small (except during storm events), and phosphorus loads measured at the Maynard gage may have been influenced by phosphorus inputs from overland runoff in the town of Maynard and from other tributaries such as Elizabeth (Assabet) Brook. Results of the application of the Wilcoxon matched-pair signed-rank tests indicate that the downstream loads at the Maynard monitoring station were significantly greater than those upstream ( $p$ less than 0.001 for TP and orthoP).

Thus, as with the Hudson impoundment, results are inconclusive as to whether the Ben Smith impoundment is a net sink of TP or orthoP. However, the results do suggest that the impoundments are not large sources of phosphorus to instream loads.
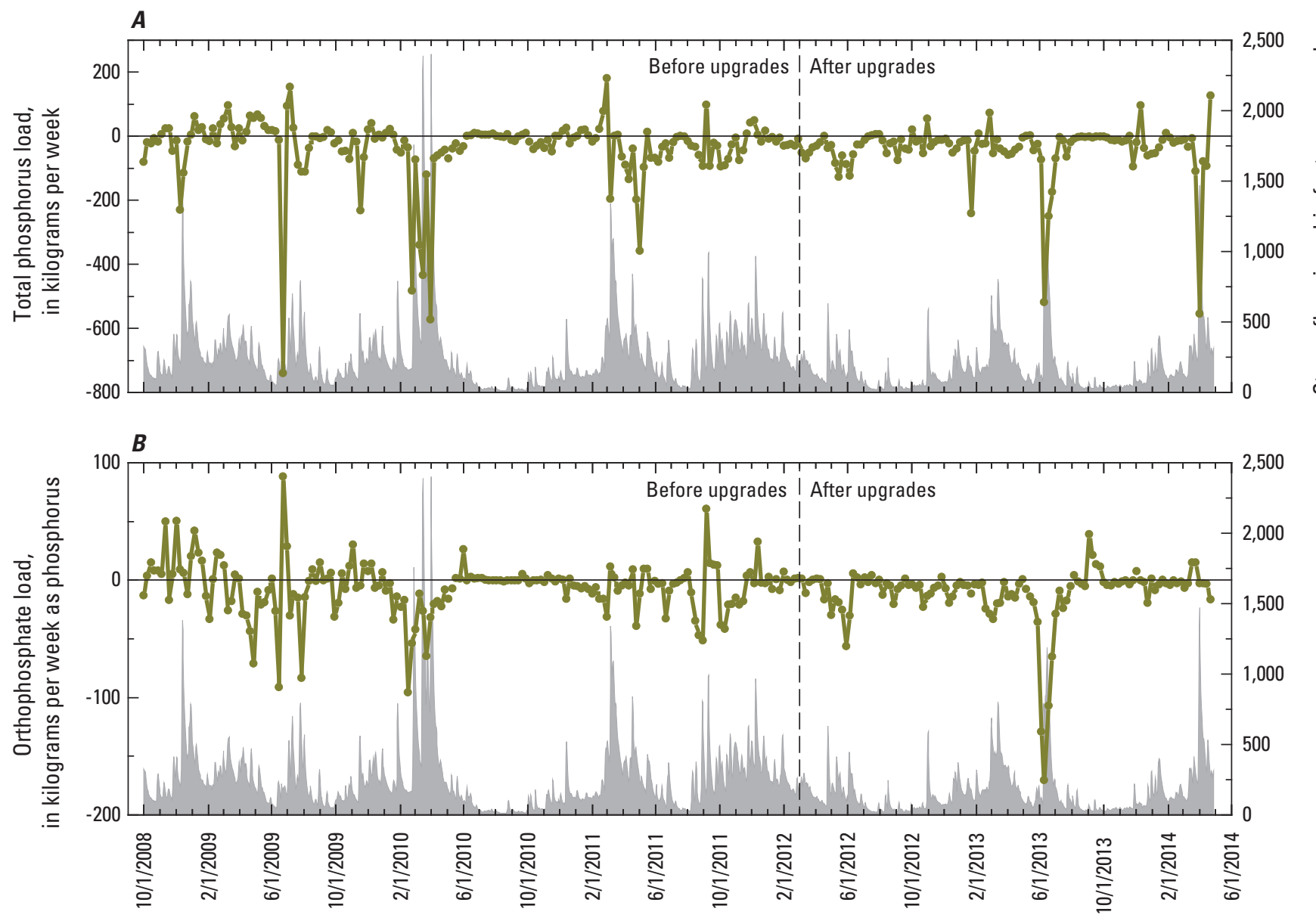

Figure 24. Streamflow and differences between estimated weekly loads of $A$, total phosphorus and $B$, orthophosphate upstream and downstream from the Ben Smith impoundment on the Assabet River, Massachusetts, October 2008 through April 2014. 


\section{Statistical Analyses of Changes in Phosphorus Concentrations}

Total phosphorus concentrations and loads in the Assabet River during the study were affected both by the changes in TP inputs that resulted from the WWTP upgrades and by the changes in streamflow that occurred seasonally and from year to year during the study period. One way to investigate the simultaneous effects of WWTP upgrades and streamflow variability is with an analysis of covariance (Helsel and Hirsch, 2002). The analysis of covariance incorporates a binary indicator variable, which distinguishes the time periods before and after the WWTP upgrades, into a multiple linear regression-equation model that also includes streamflow. TP concentrations in weekly composite samples are related to streamflow and to the indicator variable, which is 0 for the samples collected before WWTP upgrades and 1 for the samples collected after the upgrades. Streamflow in the model is the average streamflow during the weeklong samplecollection period (thus, the data fit by the models are those shown in fig. 11). With this approach, the changes in TP concentrations before and after the WWTP upgrades can be quantified and their statistical significance investigated while the variation in streamflow during the study is accounted for.

The before and after time periods were defined by March 31, 2012, the date when all WWTP upgrades were completed. Concentration and flow data were log-transformed (natural $\log$ ) for the analysis. Three regression models were used:

$$
\begin{gathered}
\ln (T P)=B 0+B 1 \times \ln (Q) \\
\ln (T P)=B 0+B 1 \times \ln (Q)+B 2 \times Z \\
\ln (T P)=B 0+B 1 \times \ln (Q)+B 2 \times Z+B 3 \times X
\end{gathered}
$$

where

$$
\begin{gathered}
\text { is total phosphorus concentration in the } \\
\text { weeklong instream composite sample, in } \\
\text { milligrams per liter; } \\
\text { is the natural log; and } \\
\text { is a binary indicator variable, } 0 \text { for the period } \\
\text { before the WWTP upgrade (October 1, } \\
\text { 2008 through March 31, 2012), and 1 } \\
\text { for the period after the WWTP upgrade } \\
\text { (April 1, 2012 through April 28, 2014). }
\end{gathered}
$$

The interaction variable $(X)$ used to describe the change in the relationship of concentration and streamflow before and after the WWTP upgrades is calculated by using $X=Z \times \ln (Q)$.

Models 2 and 3 are two different ways of describing the relation of TP concentration to streamflow and to the time period of WWTP upgrades. Model 2 would be appropriate when the slope of the relation between concentration and flow did not change before and after the time period of WWTP upgrades, whereas model 3 would be appropriate when the slope of the relation between flow and concentration changed after upgrades. The slope of the relation indicates by how much concentration changes for a given change in flow. A change in slope of the relation between flow and concentration might be expected in parts of the river where phosphorus from sources other than WWTPs is important because this phosphorus could vary with flow differently than does WWTP phosphorus. Model 1 describes the relation of TP concentration to flow only and is used in conjunction with model 3 to examine changes in the relation of concentration and flow before and after WWTP upgrades.

The three regression models were tested by using the data from each of the four water-quality-monitoring stations on the Assabet River (Savoie, 2016). Regression model response variable coefficients and their statistical significance are shown in table 4; a negative coefficient indicates an inverse relation between TP concentrations and the response variable, and a positive coefficient indicates a direct relation. Regression models were evaluated by using residual plots (fit versus response, fit versus residuals, quantile-quantile, and $\ln (Q)$ versus residuals), the significance of response variables, the adjusted R-squared, and other statistical measures.

Nested F-tests (Helsel and Hirsch, 2002) were used to select the regression model that best describes how water quality changed before and after the WWTP upgrades (table 5).

Graphs of the relation between predicted TP concentration and streamflow based on the best-fit regression model at each station are shown in figure 25 . The lines shown on these graphs, depicting the relation between concentration and flow before and after the WWTP upgrades, were calculated with the regression equation by setting the treatment indicator variable equal to 0 for the before line and equal to 1 for the after line, for the range of data available in the prediction dataset. The modeled data also are shown.

At the Maynard monitoring station, the farthest downstream station, both flow $[\ln (Q)]$ and the time period relative to WWTP upgrades (Treatment) were significantly related to TP concentrations $[\ln (T P)]$ (table 4). The coefficients for the flow and treatment variables were both negative, indicating that TP concentration was inversely related to flow and that TP concentrations were significantly lower after WWTP upgrades. The more complex regression model 3 did not provide a better fit to the data than the simpler model 2; interaction variable Treatment $\times \ln (Q)$ in model 3 was not significant at $p$ less than 0.01 . Thus, the slope of the relation between flow and concentration did not change significantly at the Maynard monitoring station after the treatment-plant upgrades. The magnitude of the difference in TP concentrations before and after WWTP upgrades that is indicated by the model for a given streamflow can be calculated from the coefficient for the Treatment variable. The coefficient for the Treatment variable was -0.324 , which corresponds to an arithmetic value of 0.723 after converting back from natural log space $[\exp (-0.324)=0.723]$. This 
Table 4. Coefficients and other regression metrics for linear regression models used to describe the relations between the natural log of composite total phosphorus concentrations and mean streamflow, and periods before and after wastewater-treatment-plant upgrades, for data collected from October 2008 through April 2014 at water-quality-monitoring stations on the Assabet River in the towns of Hudson, Stow, and Maynard, Massachusetts.

[Shading indicates model chosen and plotted in figure 25. Model equations are in the "Statistical Analyses of Changes in Phosphorus Concentrations" section of the report, in which the variable " $Z$ " represents Treatment. Full U.S. Geological Survey (USGS) station names are in table 1. Treatment, a binary variable equal to 0 before April 1, 2012, and equal to 1 on or after April 1, 2012; ln, natural log; $Q$, mean flow for composite period, in cubic feet per second; Constant, regression intercept; --, not applicable]

\begin{tabular}{|c|c|c|c|}
\hline \multirow{2}{*}{$\begin{array}{l}\text { Model variables and } \\
\text { other regression metrics }\end{array}$} & \multicolumn{3}{|c|}{ Model } \\
\hline & 1 & 2 & 3 \\
\hline \multicolumn{4}{|c|}{ Port Street (USGS station number 01096835) } \\
\hline \multicolumn{4}{|c|}{ Model response variable coefficients } \\
\hline Treatment & -- & -0.039 & $*-1.425$ \\
\hline Standard error & -- & -0.058 & -0.302 \\
\hline $\ln (Q)$ & ${ }^{*}-0.169$ & ${ }^{*}-0.175$ & ${ }^{*}-0.266$ \\
\hline Standard error & -0.031 & -0.032 & -0.036 \\
\hline Treatment $\times \ln (Q)$ & -- & -- & ${ }^{*} 0.320$ \\
\hline Standard error & -- & -- & -0.068 \\
\hline Constant & $*-1.446$ & ${ }^{*}-1.406$ & ${ }^{*}-0.982$ \\
\hline Standard error & -0.141 & -0.154 & -0.173 \\
\hline \multicolumn{4}{|c|}{ Regression metrics } \\
\hline Observations & 271 & 271 & 271 \\
\hline$R^{2}$ & 0.101 & 0.102 & 0.17 \\
\hline Adjusted $R^{2}$ & 0.098 & 0.096 & 0.161 \\
\hline Residual standard error & 0.439 & 0.439 & 0.423 \\
\hline \multicolumn{4}{|c|}{ AMVETS (USGS station number 01096840) } \\
\hline \multicolumn{4}{|c|}{ Model response variable coefficients } \\
\hline Treatment & -- & ${ }^{*}-0.524$ & $*-1.353$ \\
\hline Standard error & -- & -0.042 & -0.216 \\
\hline $\ln (Q)$ & ${ }^{*}-0.148$ & ${ }^{*}-0.213$ & ${ }^{*}-0.274$ \\
\hline Standard error & -0.028 & -0.023 & -0.027 \\
\hline Treatment $\times \ln (Q)$ & -- & -- & ${ }^{*} 0.185$ \\
\hline Standard error & -- & -- & -0.047 \\
\hline Constant & ${ }^{*}-2.026$ & ${ }^{*}-1.520$ & *-1.231 \\
\hline Standard error & -0.131 & -0.112 & -0.132 \\
\hline \multicolumn{4}{|c|}{ Regression metrics } \\
\hline Observations & 266 & 266 & 266 \\
\hline$R^{2}$ & 0.096 & 0.433 & 0.464 \\
\hline Adjusted $R^{2}$ & 0.092 & 0.429 & 0.458 \\
\hline Residual standard error & 0.41 & 0.325 & 0.317 \\
\hline
\end{tabular}

\begin{tabular}{|c|c|c|c|}
\hline \multirow{2}{*}{$\begin{array}{l}\text { Model variables and } \\
\text { other regression metrics }\end{array}$} & \multicolumn{3}{|c|}{ Model } \\
\hline & 1 & 2 & 3 \\
\hline \multicolumn{4}{|c|}{ Stow (USGS station number 01096885) } \\
\hline \multicolumn{4}{|c|}{ Model response variable coefficients } \\
\hline Treatment & -- & ${ }^{*}-0.570$ & ${ }^{*}-0.836$ \\
\hline Standard error & -- & -0.049 & -0.287 \\
\hline $\ln (Q)$ & 0.02 & -0.033 & -0.049 \\
\hline Standard error & -0.032 & -0.027 & -0.032 \\
\hline Treatment $\times \ln (Q)$ & -- & -- & 0.056 \\
\hline Standard error & -- & -- & -0.059 \\
\hline Constant & ${ }^{*}-2.914$ & ${ }^{*}-2.457$ & ${ }^{*}-2.377$ \\
\hline Standard error & -0.16 & -0.137 & -0.161 \\
\hline
\end{tabular}

Standard error

\section{Regression metrics}

Observations $\quad 273$

$R^{2}$

273

Adjusted $R^{2}$

0.001

273

$-0.002$

0.335

273

Adjusted $R^{2}$

Residual standard error

0.463

0.379

\begin{tabular}{|c|c|c|c|}
\hline \multicolumn{4}{|c|}{ Maynard (USGS station number 01097000) } \\
\hline \multicolumn{4}{|c|}{ Model response variable coefficients } \\
\hline Treatment & -- & ${ }^{*}-0.324$ & -0.608 \\
\hline Standard error & -- & -0.053 & -0.319 \\
\hline $\ln (Q)$ & -0.012 & $\dagger-0.080$ & $\dagger-0.104$ \\
\hline Standard error & -0.031 & -0.031 & -0.041 \\
\hline Treatment $\times \ln (Q)$ & -- & -- & 0.056 \\
\hline Standard error & -- & -- & -0.062 \\
\hline Constant & ${ }^{*}-2.814$ & $*-2.340$ & $*-2.209$ \\
\hline Standard error & -0.161 & -0.169 & -0.223 \\
\hline \multicolumn{4}{|c|}{ Regression metrics } \\
\hline Observations & 261 & 261 & 261 \\
\hline$R^{2}$ & 0.001 & 0.128 & 0.13 \\
\hline Adjusted $R^{2}$ & -0.003 & 0.121 & 0.12 \\
\hline Residual standard error & 0.415 & 0.388 & 0.388 \\
\hline
\end{tabular}

"Value significant at less than 0.01 .

†alue significant at less than 0.05 . 
Table 5. Results of pairwise F-test comparison of linear regression models 1, 2, and 3 for four water-quality-monitoring stations on the Assabet River, Massachusetts.

[See Helsel and Hirsch (2002) for information on nested F-tests. Model 1 relates the natural $\log$ of total phosphorus concentration $[\ln (T P$ concentration $)]$ to the natural log of flow $[\ln ($ flow $)]$. Model 2 relates $\ln (T P$ concentration) to $\ln ($ flow $)$ and an indicator variable describing time period relative to wastewater-treatment-plant (WWTP) upgrades. Model 3 relates $\ln$ (TP concentration) to $\ln ($ flow $)$, an indicator variable describing time period relative to WWTP upgrades, and an interaction variable of $\ln ($ flow $)$ and time period. See the "Statistical Analyses of Changes in Phosphorus Concentrations" section of the report for model equations. See table 1 for full U.S. Geological Survey (USGS) station names. <, less than]

\begin{tabular}{lccc}
\hline \multirow{2}{*}{ F-test results } & \multicolumn{3}{c}{ Models compared } \\
\cline { 2 - 4 } & 2 versus 1 & 3 versus 1 & 3 versus 2 \\
\hline Port Street (USGS station number 01096835) \\
\hline F statistic & 0.4581 & 11.168 & 21.842 \\
F probability & 0.4991 & $<0.0001$ & $<0.0001$ \\
Better-fit model & 1 & 3 & 3 \\
\hline \multicolumn{4}{c}{ AMVETS (USGS station number 01096840) } \\
\hline F statistic & 156.69 & 90.203 & 15.235 \\
F probability & $<0.0001$ & $<0.0001$ & 0.0001 \\
Better-fit model & 2 & 3 & 3 \\
\hline \multicolumn{4}{c}{ Stow (USGS station number 01096885) } \\
\hline F statistic & 135.47 & 68.152 & 0.8871 \\
F probability & $<0.0001$ & $<0.0001$ & 0.3471 \\
Better-fit model & 2 & 3 & 2 \\
\hline \multicolumn{5}{c}{ Maynard (USGS station number 01097000) } \\
\hline F statistic & 35.577 & 19.183 & 0.815 \\
F probability & $<0.0001$ & $<0.0001$ & 0.3675 \\
Better-fit model & 2 & 3 & 2 \\
\hline
\end{tabular}

means that TP concentrations after WWTP upgrades averaged 72.3 percent of the concentrations before upgrades, which is a reduction of about 30 percent relative to before-upgrade concentrations (fig. 25D). Note that the adjusted $R^{2}$ value of the model was low (0.121). Thus, although flow and time period relative to upgrades were significant predictors of concentration, the data were widely scattered, and other factors, not represented by equation variables, accounted for much of the variability in concentration.

At the AMVETS monitoring station, as at the Maynard monitoring station, both flow $[\ln (Q)]$ and the time period relative to WWTP upgrades (Treatment) were significantly related to TP concentrations $[\ln (T P)]$, and the coefficients for both variables were negative (table 4 ). However, the relation between flow and concentration at the AMVETS monitoring station, in contrast to that at the Maynard monitoring station, changed after the upgrades, and the best-fit regression model to describe TP concentrations was model 3. The adjusted
$R^{2}$ value for model 3 at the AMVETS monitoring station, 0.458 , was the highest adjusted $R^{2}$ value for any model at all four stations, indicating that the multiple linear regression model at this station was best at explaining the observed variation in TP concentrations. Because of the change in the slope of relation between streamflow and concentration, the difference in TP concentrations indicated by the model varied by streamflow; for example, TP concentrations declined about $0.07 \mathrm{mg} / \mathrm{L}$ (about 45 percent of before-upgrade concentrations, a reduction of about 55 percent) for $20 \mathrm{ft}^{3} / \mathrm{s}$, but only about $0.01 \mathrm{mg} / \mathrm{L}$ for streamflow near $370 \mathrm{ft}^{3} / \mathrm{s}$ (about 77 percent of before-upgrade concentrations, a reduction of about 23 percent; fig. $25 B$ ).

At the Stow monitoring station, TP concentrations were significantly and inversely related to the Treatment variable, indicating that, as at the Maynard and AMVETS monitoring stations, TP concentrations were significantly lower after WWTP upgrades. However, there was no significant relation (table 4) between TP concentrations and flow $[\ln (Q)]$ at the Stow monitoring station. Thus, model 3 did not provide a better fit to the data at the Stow monitoring station, and model 2 was the best-fit model. The adjusted $R^{2}$ value of 0.33 for model 2 indicates that this regression model provides a better fit to the data at the Stow monitoring station than the best-fit model at the Maynard monitoring station, but not as good a fit as the best-fit model at the AMVETS monitoring station. The coefficient for the Treatment variable in model 2 was -0.570 , such that the model describes concentrations after WWTP upgrades as averaging 56.6 percent of the concentrations before upgrades, which is a reduction of about 40 percent; fig. $25 C$; table 4 , model 2 ).

At the Port Street monitoring station, although the flow variable $[\ln (Q)]$ and (or) the Treatment variable were significant in models 2 and 3, examination of model residuals (table 4 ) and the low adjusted $R^{2}$ values indicated that none of the regression models provided good fits to the data. Visual inspection of the plotted data suggest an inverse relation between TP concentration and flow before WWTP grades that was not apparent after WWTP upgrades (figs. 11 and 25A), but this may have been an artifact of high flows before upgrades and the effects of resuspension near the end of the study period. Overall, TP concentrations at the Port Street monitoring station behaved differently than those at the other stations after WWTP upgrades, as noted previously, and results at the Port Street monitoring station are difficult to interpret.

The statistical analysis demonstrates significant reductions in TP concentrations before and after the WWTP upgrades at three of the four monitoring stations. The finding, that the Treatment indicator variable is a significant predictor of TP concentrations even when streamflow is included in the equation, can be interpreted to mean that, for any given streamflow measured at the AMVETS, Stow, or Maynard monitoring stations, TP concentrations after WWTP upgrades were significantly lower than concentrations at the same streamflow before upgrades (Robert Hirsch, U.S. Geological Survey, written commun., 2015). At the downstream stations, 

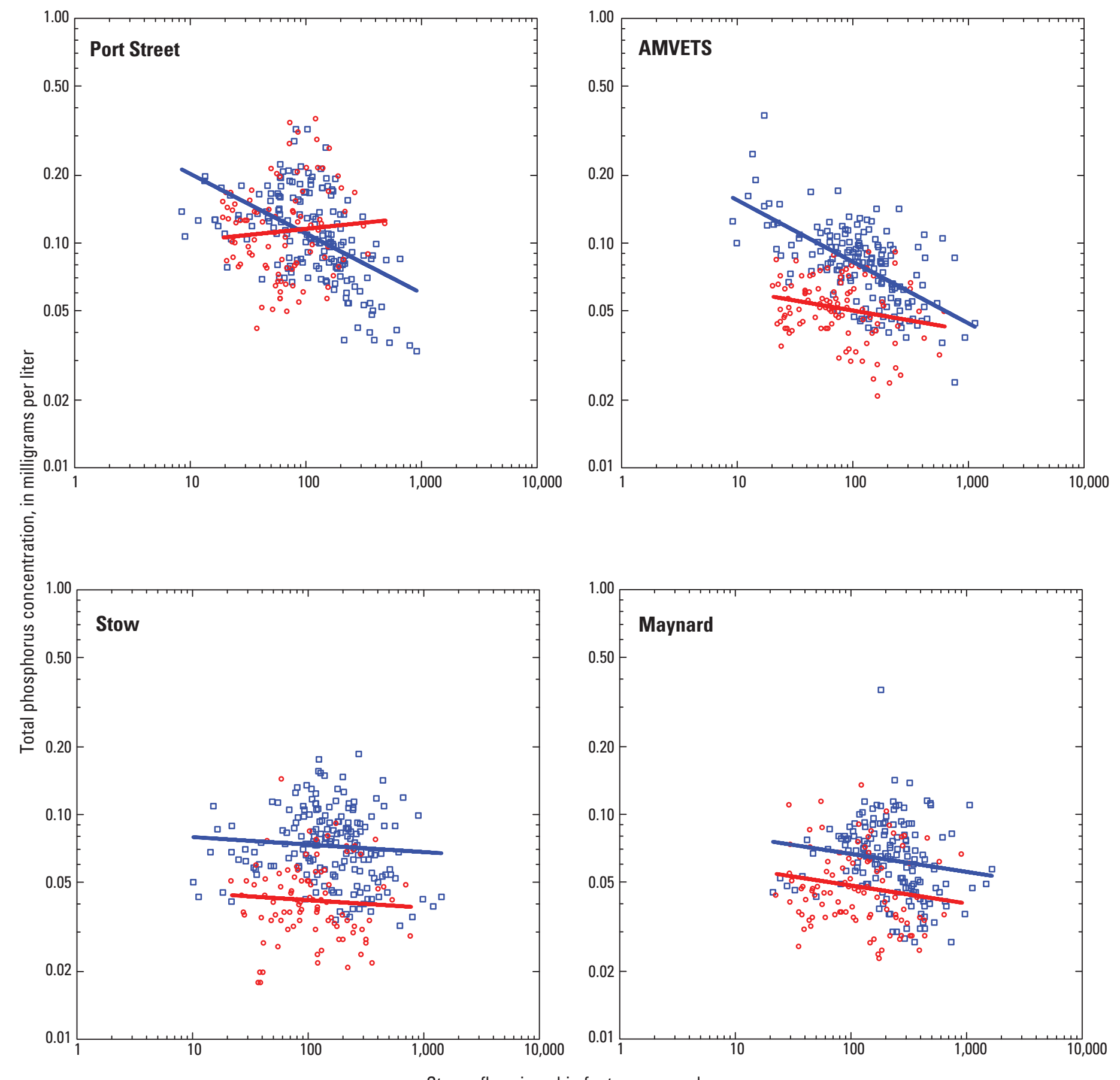

Streamflow, in cubic feet per second

\section{EXPLANATION}

$\begin{array}{ll}\text { — } & \text { Total phosphorus predicted, before WWTP upgrade } \\ -\quad \text { Total phosphorus predicted, after WWTP upgrade } \\ \square \quad \text { Total phosphorus, before WWTP upgrade } \\ \text { } \quad \text { Total phosphorus, after WWTP upgrade }\end{array}$

Figure 25. Relations between streamflow and total phosphorus concentrations, and total phosphorus concentrations predicted for before and after the wastewater-treatment-plant (WWTP) upgrades, based on linear regression modeling for data from 0ctober 2008 through April 2014 for water-quality-monitoring stations on the Assabet River in the towns of Hudson (two stations, Port Street and AMVETS), Stow, and Maynard, Massachusetts. Refer to table 4 for the regression model used in each plot. See table 1 for full station names and numbers. 
Stow and Maynard, reductions were such that, for any given streamflow before or after WWTP upgrades, TP concentrations after upgrades were about 60 to 70 percent of concentrations before upgrades, corresponding to reductions of 30 to 40 percent. At the AMVETS monitoring station, further upstream, the magnitude of the reduction in concentration varied by streamflow; reductions were larger, as fractions of before-upgrade concentrations, at lower streamflows than at higher streamflows. A tighter inverse relation between TP concentration and flow at the AMVETS monitoring station than at the Stow or Maynard monitoring stations is reasonable because flows are lower at the AMVETS monitoring station, and the AMVETS monitoring station is closer to the large WWTP inputs than the Stow and Maynard monitoring stations are; thus, wastewater phosphorus changes are more readily apparent at the AMVETS monitoring station. These reductions in TP concentrations for given streamflows calculated at the AMVETS, Stow, and Maynard monitoring stations also apply to reductions in TP loads, because loads are calculated as the product of concentration times streamflow.

\section{Summary and Conclusions}

The Assabet River in central Massachusetts, valued for its scenic beauty, biological diversity, and history, was listed by the Massachusetts Department of Environmental Protection as an "impaired river" in 2004 with respect to nutrients, organic enrichment, and low dissolved oxygen. Problematic aquatic plant growth and decay during summer months not only detracts from the aesthetics of the river but also decreases oxygen levels and threatens the habitat of many aquatic species.

In 2004, a total maximum daily load (TMDL) was established by the U.S. Environmental Protection Agency for total phosphorus (TP) for the Assabet River. The TMDL required the wastewater-treatment plants (WWTPs) in the towns of Westborough, Marlborough, and Hudson, Massachusetts, to limit monthly average effluent TP concentrations to 0.1 milligram per liter $(\mathrm{mg} / \mathrm{L})$ during April through October and $1.0 \mathrm{mg} / \mathrm{L}$ during November through March. All WWTP upgrades were completed and the TMDL-mandated limits were achieved in March 2012.

From October 2008 through April 2014, the U.S. Geological Survey, in cooperation with the Massachusetts Department of Environmental Protection, measured streamflow and collected flow-proportional TP and orthophosphate (orthoP) samples composited for 1-week periods at four locations : station number 01096835, Assabet River at Port Street at Hudson, Mass. (Port Street); 01096840, Assabet River 200 feet below State Route 85 at Hudson, Mass. (AMVETS); 01096885, Assabet River at Sudbury Road near Stow, Mass. (Stow); and 01097000, Assabet River at Maynard, Mass. (Maynard). The goals of the study were to document changes in phosphorus concentrations and loads before, during, and after implementation of the TMDL, to assess the effects of seasonal differences in mandated effluent TP concentrations, and to examine the effects of two run-of-theriver reservoirs on the Assabet River phosphorus dynamics. The study period included almost 3 years of observations prior to the full WWTP upgrades and 2 years of observations after the upgrades. Wastewater-treatment-plant concentrations and loads were compared with concentrations and loads measured in the river, and seasonal WWTP variations in effluent TP concentrations and loads were compared with seasonal concentrations and loads measured in the river. The waterquality-monitoring stations were upstream and downstream from two impoundments, and the changes in TP and orthoP entering and leaving the impoundments on an annual basis were assessed.

Following completion of the TMDL-mandated upgrades, three WWTPs reported reductions in effluent TP annual median concentrations of more than 80 percent relative to before-TMDL implementation concentrations. Annual median TP concentrations in the WWTP effluent for 2012 and 2013 were all under the TMDL-required limit of $0.1 \mathrm{mg} / \mathrm{L}$. Total phosphorus concentrations measured in weekly composite samples collected in proportion to flow were similar at three of the four instream monitoring stations, with reduction in the annual median TP concentrations of about 38 to 50 percent. Reductions of TP concentrations measured instream were not as great as reductions at the WWTPs because instream phosphorus was diluted by inflows of runoff and (or) groundwater discharge. Concentrations at the fourth monitoring station, Port Street, were different than at the other downstream stations. Concentrations at the Port Street monitoring station showed large amounts of total phosphorus but not orthoP (the filtered sample, or dissolved form of phosphorus) in several high-flow samples, which suggests that particulates were high and that the difference may be related to seasonal and (or) flow-related resuspension of particulate phosphorus at the location of the station.

The calculation of loads accounts for the variability of phosphorus concentrations and the hydrologic system during sample collection, and calculated loads represent the mass of phosphorus instream. Annual median TP loads released at the WWTPs were reduced by 87 to 91 percent following completion of the TMDL-mandated upgrades, and the reductions were reflected at three of the four the four instream monitoring stations, where annual median TP loads decreased by 71 to 76 percent. In particular, the reductions in median TP instream loads between 2009 and 2013 were comparable to the reductions in WWTP loads and differed only by 13 percent at the AMVETS monitoring station, 20 percent at the Stow monitoring station, and 8 percent at the Maynard monitoring station.

Streamflow varied during the study period and was higher during the initial years and near or below average during the final years. Consequently, changes in TP were investigated by using a statistical analysis (analysis of covariance) that 
incorporates the effects of variable flow conditions. That analysis demonstrated that the observed reductions in TP concentrations after the WWTP upgrades were statistically significant at three of the four instream monitoring stations, regardless of differences in streamflow during the study period. At the downstream monitoring stations at Stow and Maynard, reductions were such that, for any given streamflow before or after WWTP upgrades, TP concentrations after upgrades were reduced by 30 to 40 percent relative to before-upgrade concentrations. At the AMVETS monitoring station, further upstream, the magnitude of the reduction in concentration varied by streamflow; reductions were larger, as fractions of before-upgrade concentrations, at lower streamflows than at higher streamflows. No significant change was observed at the most upstream location at the Port Street monitoring station, which may have been affected by flowrelated resuspension of particulate phosphorus.

Increased effluent TP concentrations permitted under the TMDL requirements during the nongrowing season (November through March) did not result in major seasonal differences in concentrations or loads of TP or orthoP at the four instream monitoring stations. Despite a permitted TP effluent concentration of $1.0 \mathrm{mg} / \mathrm{L}$ in the nongrowing season, the median effluent concentrations after the WWTP upgrades ranged from about 0.06 to $0.1 \mathrm{mg} / \mathrm{L}$, well below the limit of $1.0 \mathrm{mg} / \mathrm{L}$. Loads monitored at the four instream stations showed less seasonal variability than those at the WWTPs.

Hudson impoundment, which occupies a shorter stretch of the Assabet River than Ben Smith impoundment, may have been a sink for particulate phosphorus on an annual basis, considering that loads of TP entering the impoundment were larger than those leaving during all 5 complete years of the study. However, there was uncertainty about the loads at the upstream monitoring station at this impoundment. TP and orthoP loads leaving Ben Smith impoundment were slightly greater than those that entered the impoundment during each complete year of the study. The differences are not large and may reflect additions from tributaries and overland runoff between the stations and in downtown Maynard.

The use of automated weekly, flow-proportional sampling and continuous streamflow monitoring provided an accurate measure of changing phosphorus concentrations and loads in this highly variable river system that is dominated by WWTP effluent. High-frequency (weekly to hourly) changes in instream phosphorus concentrations would not have been evident if a monthly or weekly sampling schedule were used, even if an attempt was made to adequately sample all stations during storms. Continuous, flow-proportional sampling, however, produced a complete record of the year-to-year changes and permitted a direct comparison of the relative magnitudes of the phosphorus-load reductions at the WWTPs and the monitoring stations.

\section{References Cited}

ENSR International, 2001, SuAsCo watershed Assabet River TMDL study, phase one-Assessment final report: Westford, Mass., ENSR International, U.S. Army Corps of Engineers, and Massachusetts Department of Environmental Protection, November, variously paged.

Fishman, M.J., ed., 1993, Methods of analysis by the U.S. Geological Survey National Water Quality LaboratoryDetermination of inorganic and organic constituents in water and fluvial sediments: U.S. Geological Survey OpenFile Report 93-125, 217 p., accessed July 23, 2015, at http://nwql.usgs.gov/rpt.shtml?OFR-93-125.

Helsel, D.R., and Hirsch, R.M., 2002, Statistical methods in water resources: U.S. Geological Survey Techniques of Water-Resources Investigations, book 4, chap. A3, 522 p., accessed November 4, 2014, at http://pubs.usgs.gov/twri/ twri4a3.

Massachusetts Department of Environmental Protection, 2004, Assabet River total maximum daily load for total phosphorus: [Massachusetts] Executive Office of Environmental Affairs report MA82B-01-2004-01, 104 p., accessed April 9, 2015, at http:/www.mass.gov/eea/docs/dep/water/ resources/a-thru-m/anuttmdl.pdf.

Mueller, D.K., Schertz, T.L., Martin, J.D., and Sandstrom, M.W., 2015, Design, analysis, and interpretation of field quality-control data for water-sampling projects: U.S. Geological Survey Techniques and Methods, book 4, chap. C4, 54 p., accessed July 23, 2015, at http://dx.doi.org/10.3133/ tm4C4.

National Oceanic and Atmospheric Administration, 2015, Annual total precipitation data, Natick, Massachusetts: National Oceanic and Atmospheric Administration climate data online data tools, accessed June 25, 2015, at http://www.ncdc.noaa.gov/cdo-web/datatools/findstation.

Rantz, S.E., and others, 1982, Measurement and computation of streamflow: U.S. Geological Survey Water-Supply Paper 2175, 2 v., 631 p., accessed July 23, 2015, at http://pubs.usgs.gov/wsp/wsp2175/.

Savoie, J.G., 2016, Streamflow and total phosphorus and orthophosphate data for samples collected in and near the Assabet River, Massachusetts, October 2008 through April 2014: U.S. Geological Survey data release, accessed October 2016 at http://dx.doi.org/10.5066/F72R3PR3.

U.S. Environmental Protection Agency, 1993, Method 365.1, Determination of phosphorus by semi-automated colorimetry revision 2.0-Methods for the determination of inorganic substances in environmental samples: U.S. Environmental Protection Agency, EPA/600/R-93/100, 172 p. 
U.S. Environmental Protection Agency, 2015a, Implementing Clean Water Act section 303(d)-Impaired waters and total maximum daily loads (TMDLs): U.S. Environmental Protection Agency Web page, accessed June 22, 2015, at http:/water.epa.gov/lawsregs/lawsguidance/cwa/tmdl/overviewoftmdl.cfm.

U.S. Environmental Protection Agency, 2015b, Six municipalities, one watershed-A collaborative approach to remove phosphorus in the Assabet River watershed: U.S. Environmental Protection Agency Web page, accessed February 29, 2016, at http:/www.epa.gov/sites/production/files/2015-03/ documents/assabet-river-removal-casestudy.pdf.

U.S. Geological Survey, 2006, Collection of water samples (ver. 2.0, September 2006): U.S. Geological Survey Techniques of Water-Resources Investigations, book 9, chap. A4, accessed July 23, 2015, at http://pubs.water.usgs.gov/ twri9A4/.

Zimmerman, M.J., and Savoie, J.G., 2013, Monitoring to assess progress toward meeting the total maximum daily load for phosphorus in the Assabet River, MassachusettsPhosphorus loads, 2008 through 2010: U.S. Geological Survey Scientific Investigations Report 2013-5140, 41 p., accessed July 23, 2015, at http://pubs.usgs.gov/ $\operatorname{sir} / 2013 / 5140 /$.

Zimmerman, M.J., and Sorenson, J.R., 2005, Sediment studies in the Assabet River, central Massachusetts, 2003: U.S. Geological Survey Scientific Investigations Report 20055131, 87 p., accessed February 10, 2016, at http://pubs.usgs. gov/sir/2005/5131/. 
For more information concerning this report, contact: Director, New England Water Science Center U.S. Geological Survey 10 Bearfoot Road

Northborough, MA 01532

dc_nweng@usgs.gov or visit our Web site at: http://newengland.water.usgs.gov/

Publishing support by:

The Pembroke Publishing Service Center 

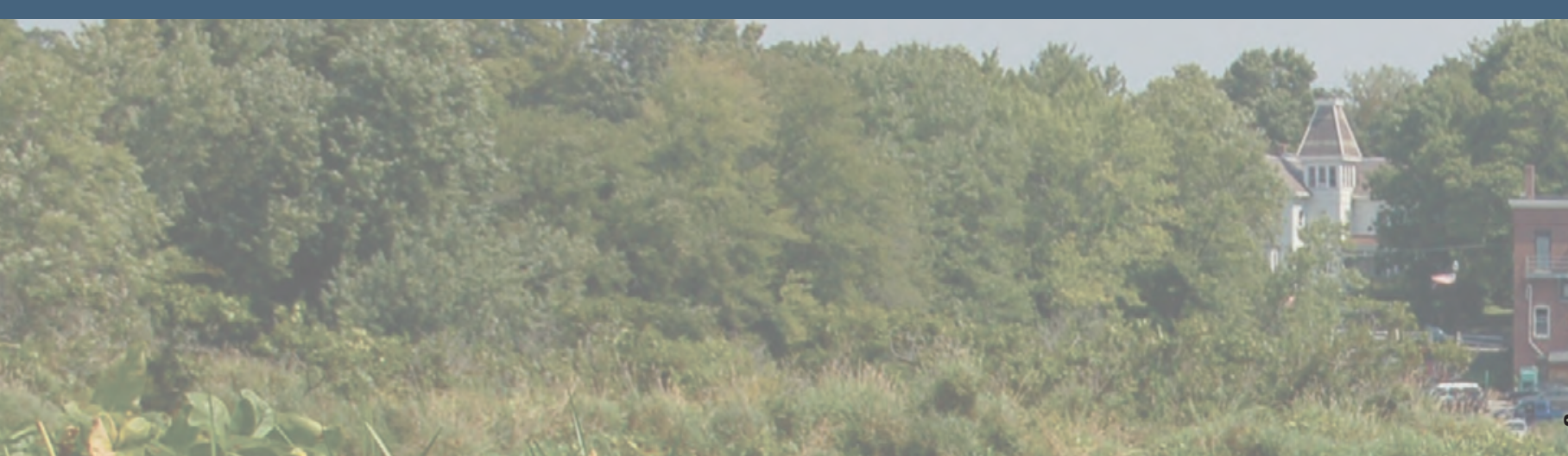

20.

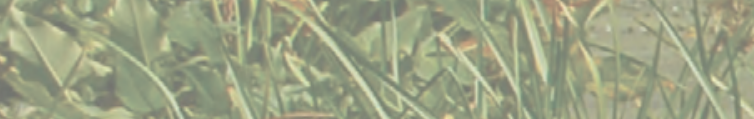

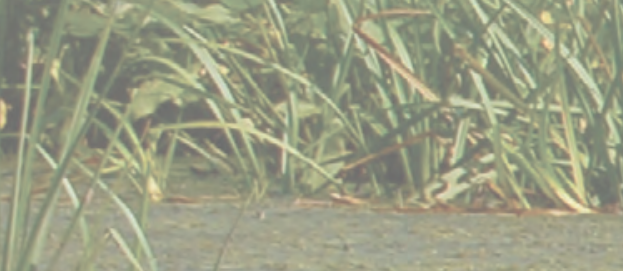

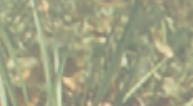

